\title{
RELIGION AND POLITICS IN SOUTHERN AFRICA
}

Edited by

Carl Fredrik Hallencreutz and Mai Palmberg

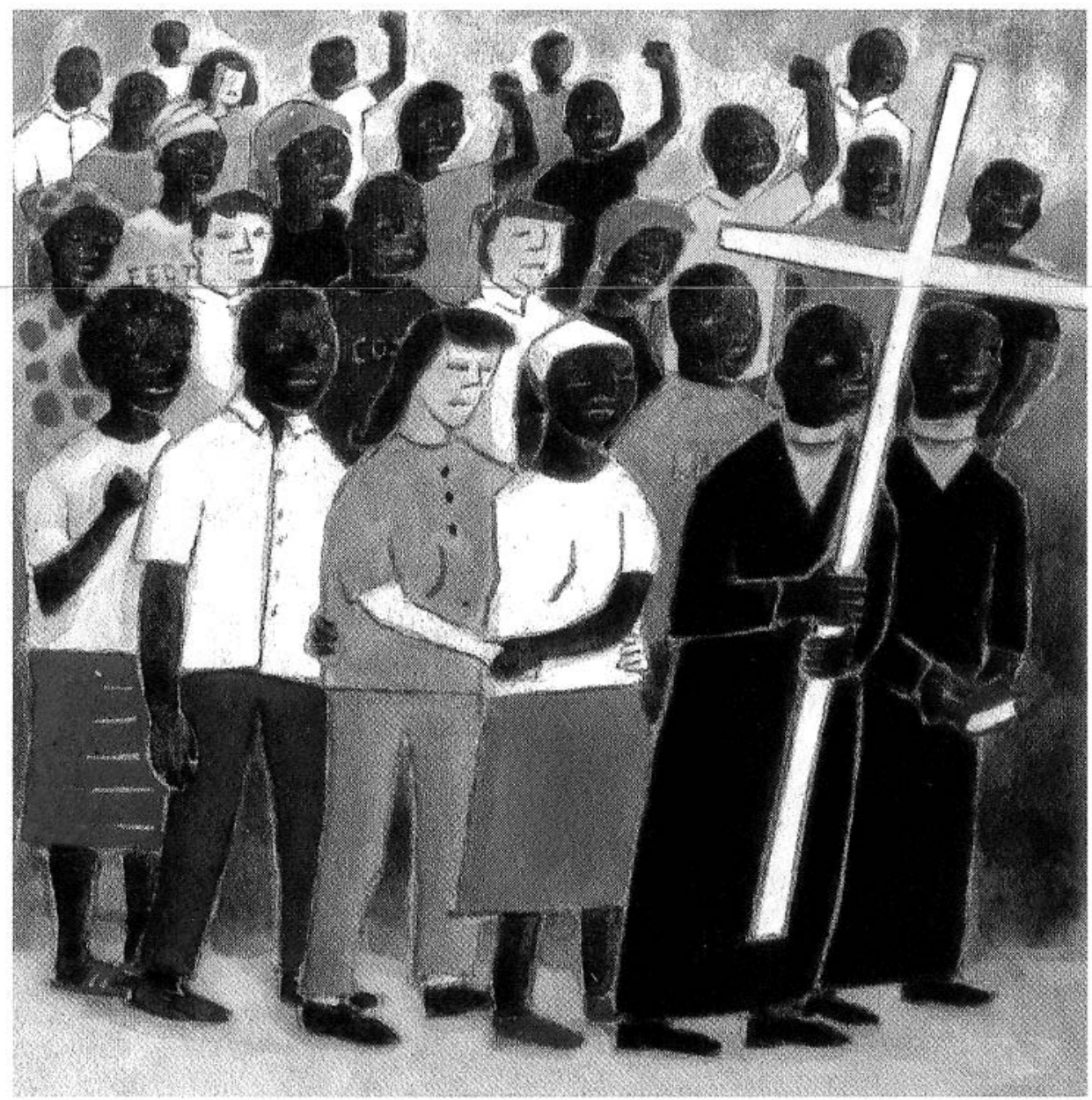

Seminar Proceedings No. 24

The Scandinavian Institute of African Studies 

RELIGION AND POLITICS IN SOUTHERN AFRICA 

Seminar Proceedings No. 24

\section{RELIGION AND POLITICS IN SOUTHERN AFRICA}

Edited by

Carl Fredrik Hallencreutz and Mai Palmberg

The Scandinavian Institute of African Studies, Uppsala 1991 


\section{Indexing terms}

Religion

Church

Politics

Southern Africa

Cover drawing: Anna Bengtsson

(The cover picture is inspired by a part in Desmond Tutu's speech in Uppsala, reprinted here.)

Typesetting: Leena Kjallstrom, Susanne Ljung

Stylistic editing: Nigel Rollison

(C) Nordiska Afrikainstitutet, 1991

Printed in Sweden by

Bohuslaningens Boktryckeri AB, Uddevalla 1991

ISSN 0281-0018

ISBN 91-7106-312-9 


\section{Contents}

PREFACE

INTRODUCTION

Carl F. Hallencreutz

THE SOUTHERN AFRICAN SCENARIOS

The Call of the ANC

Billy Modise

In Commemoration of Soweto 1976

Lisbet Palme

"In Humble Submission to Almighty God" —Church, State and Conflict in South Africa

Sheena Duncan

Has Apartheid Gone?

41

Axel Ivar Berglund

Namibia - A Sign of Hope?

48

Jose' Chipenda

The Regional Prospects

57

Tor Sellström

RELIGION, APARTHEID AND AFTER

Towards Post-ApartheidSouth Africa

67

Desmond Tutu

The Role of Islam in Southern Africa

Ephraim Mandivenga

African Independent Churches and their Political Roles Bengt Sundkler 
Healing and Political Aquiescence in African

Independent Churches

Matthew Schoffeleers

A New Religious Political Right

Ove Gustafsson

The Theological Debate on Liberation

Per Frostin

LESSONS FROM ZIMBABWE

Insights from the Second Chimurenga

Patrick Mutume

Catholic Youth Mobilization in Zimbabwe

Paul Gundani

Church and State in Zimbabwe and South Africa

Carl F. Hallencreutz

The Role of the Church in the Development Market

- The Case of Zimbabwe

Agnes Chepkwony Ongaro

CONTEXTUALIZINGHISTORY

Learning from History: Religion, Politics, and the Problem of Contextualization - The Case of J.W. Colenso

Jeff Guy

Catholics and Protestants in a Clash of Interests in Southern Mozambique

Alf Helgesson

CONCLUDING REMARKS

Jose' Chipenda

Sigbert Axelson and Carl F. Hallencreutz

CONTRIBUTORS 


\section{Preface}

The interlinkages between religion and politics in Southern Africa is a topical subject at a time when serious thought is being given to what a Post-Apartheid Society will look like by academics from outside as well as by scholars and politicians within the Liberation movement. This subject was explored at considerable depth at the third major research seminar jointly convened by the Scandinavian Institute of African Studies and the Nordic Institute of Missionary and Ecumenical Research (NIME) in Uppsala, Sweden, June 14-18, 1989. Material from that seminar has provided the source for this book.

The organizing committee, comprising of Bertil Odén, Thomas Ridæus and Annica van Gylswyk from the Scandinavian Institute of African Studies, and Axel Ivar Berglund, Ove Gustafsson and Carl Fredrik Hallencreutz from NIME, enlisted a very rewarding response in the form of a most representative participation from the ANC and related agencies, scholars and Church leaders from the region as well as academic scholars and representatives of agencies for Mission and Development from the Nordic scene. Generous financial support from the Swedish Government and involved missionary and developmentaid agencies allowed the plans of the organizing committee to become a reality.

Editorial responsibility for the sharing of contributions made and insights gained in the course of the seminar has rested with a committee of the undersigned, with Lars Berge as editorial assistant. It should be noted that the papers and speeches delivered at the seminar have been edited and shortened, almost without exception, but always with the author's permission.

Leena Kjallstrom of the Uppsala Department of Theology and Susanne Ljung of the Scandinavian Institute of African Studies have made unfailing efforts in providing the finished texts.

Uppsala, February 1991

Carl F. Hallencreutz

Department of Theology

Uppsala University, and NIME
Mai Palmberg

The Scandinavian Institute

of African Studies 



\section{Introduction}

\section{Curl F. Hallencreutz}

In June 1989 the third major interdisciplinary Uppsala seminar on Religion and Society in Africa was convened with the Scandinavian Institute of African Studies as one of the organizers. The theme this time was Religion and Politics in Southern Africa. Discussions proved again to be highly relevant and thought-provoking.

Being the third of its kind, this seminar has a pre-history. The first major scholarly Uppsala encounter on Religion and Society in Africa took place when Uppsala University celebrated its Fifth Centenary in 1977. In fact, discussions were then pursued in two stages: first there was a special subsection on African Church History within the framework of an international conference on Ecclesiastical History. Secondly, there was an additional two-day workshop at SIAS, which mainly dealt with the proposed outline of Bengt Sundkler's forthcoming comprehensive account of the Christian Movement in Africa, These discussions, were also most rewarding. Material from these Uppsala deliberations on African Church History is available in The Church in a Changing Society, Uppsala 1977.

The second step towards the 1989 Uppsala Seminar on Religion and Politics in Southern Africa was a research seminar in August 1984 on Religion, Development and African Identity. At that time SIAS shared responsibility for the arrangements with the Nordic Institute of Missionary and Ecumenical Research (NIME or NIMER). Issues explored on that occasion included contemporary religious change, church and state in post colonial Africa, and the role of women in church and society in traditional and modem Africa. In the course of the proceedings, Bengt Sundkler gave a progress report on his re-assessment of dynamics and perspectives in African church history from "the flight of the Holy Family to Egypt" until the present day. Material from this research seminar has been published in Religion, Development and African Identity, Seminar Proceedings No. 17, Uppsala 1987.

When the third major Uppsala seminar on Religion and Society in Africa was launched - again in the form of a joint venture, Religion and 
Politics in Southern Africa proved to be a highly topical theme. The primary objective was defined in terms of a critical assessment of the relevance of ongoing Scandinavian studies in the field of religion and society in Africa in light of the increasingly specific discussions within $\mathrm{ANC}$ and related agencies on the one hand, and in more independent fora on the other.

Again the scholarly encounter proved challenging due to the representative and varied participation from Southern Africa. And again Bengt Sundkler took an active part. In a special seminar group on church history he highlighted some specific findings with regard to Church developments in Southern Africa. The manuscript for his overall presentation was just being finalized for transfer to his publisher in Cambridge. In a plenary session he was invited to review his pioneering studies of Independent Church Movements in Southern Africa in light of the main focus of the seminar.

The third major Uppsala seminar on Religion and Society in Africa operated at three levels. Within the seminar proper, discussions were pursued both in plenary sessions and in more specialized seminar groups. There were also two significant public events; the first on Soweto Day, June 16; the second in the form of an ecumenical solidarity meeting on Sunday, June 18.

Material which is published in this volume also contains contributions from these public events. We are privileged in being able to publish Lisbet Palme's plea on behalf of suffering children in Southern Africa at the public meeting on Soweto Day 1989, as well as Archbishop Desmond Tutu's equally compassionate reflections on the role of the Church in striving towards a South Africa freed from apartheid at the subsequent ecumenical solidarity meeting.

There were many categories of people involved in the seminar at various levels. I have already mentioned two distinguished guests. Moving on, I will suggest that there were at least four categories of participants. In the first place there were representatives of ANC and related organisations, most notably the Rev. Fumanekile Gquiba of the Department of Religious Affairs of ANC, and the Chief Representative of the ANC to the Nordic Countries, Billy Modise. Secondly, there were some very experienced and able Church leaders and scholars from the Southern Africa region, including Patrick Mutume of the Zimbabwe Catholic Bishops Conference and Ephraim Mandivenga, well- 
known Islamologist from the University of Zimbabwe, as well as Gabriel Setiloane from the University of Cape Town and Sheena Duncan of Black Sash in Johannesburg. Thirdly, there were Scandinavian - and indeed some African! - research students and scholars such as Agnes Chepkwony Ongaro from Kenya and Sweden, Paul Gundani of Zimbabwe, and participants from four of the Nordic Countries. And fourthly, there were representatives of Non-Governmental Organisations and Missions involved in the region and also sponsors of the seminar. The Minister of International Development Cooperation Lena Hjelm-Wallén officially opened the seminar proceedings.

$\boldsymbol{O} \boldsymbol{f}$ course, such a varied participation had varying expectations and their priorities differed. However, this diversity contributed to make seminar discussions and personal exchanges even more challenging and, indeed, informative. This diversity is reflected in papers included in this volume.

In introducing this volume it is necessary also to underline the deliberate focus on Religion and Politics. Two specific issues are involved here. In the first place, the title suggests that in continued studies of political developments in Southern Africa the role of religion cannot be overlooked. Secondly, as Gabriel Setiloane convincingly argued in his introductory statement in the third seminar group, postapartheid South Africa, too, will be a multi-religious state. Reflections on Church and State have, thus, to be broadened to include also the role of traditional religions and Islam in assessing continued political developments. With this in mind it was particularly disappointing that the South African authorities withheld Maulana Farid Eshaq's passport, thus making it impossible for him to contribute to our research seminar.

It should again be noted that the material which is published in this book is from a research-seminar which was held in June 1989. Since then much has happened which was not possible to anticipate at the time of the seminar: Nelson Mandela is released, Oliver Tambo has recovered from his stroke, serious attempts are made to initiate negotiations for peace in a post-apartheid South Africa between President de Klerk's administration and ANC. From the Uppsala horizon it is in this context proper to add with some pride a reference to Mr Mandela's challenging message on religon and politics at the ecumenical service for peace and solidarity at Uppsala Cathedral on March 14, 1990.

Against this background our volume may seem to be out of date, or 
perhaps, mainly of historical interest. However, most of the issues dealt with at our Uppsala seminar still remain. Furthermore I am inclined to suggest that the way in which these issues were explored has something to say of how continued reflections on religion and politics in postapartheid South Africa shall be pursued. It is as a contribution to such deliberations that our seminar proceedings in this way are shared with a wider audience in South Africa and beyond. 


\section{The Southern African Scenarios}





\section{The Call of the ANC}

Billy Modise

I will start off by giving an unpleasant analogy which I think reflects what Southern Africa is, or South Africa in particular. My first assignment when I came over to Europe on this job was to fly back to Paris to bury a middle-aged Comrade, Dulcie September.

It is nothing spectacular to go to a funeral but she had been killed by an assassin when she was unarmed and when she was unlocking her office door. She was middle-aged and therefore could not even fight physically.

The assassin used six bullets. The first bullet was intended to kill her. The second bullet was aimed to see that the first bullet did do its job. The other four were intended for the future. In case for some reason she did resurrect there were already four bullets to kill her so that she can never ever resurrect.

That is exactly what South Africa is and that is why we call it a crime against humanity. They not only kill today. They kill even a possible life tomorrow. They do so at all levels. Inside South Africa it is at the level of physical killings, assassinations etc. of opponents of apartheid. It is killing these people through exploitation of their labour. In the neighbouring states it is again physical elimination of peoples in these countries and destabilisation of their economies.

More seriously, these killings are to ensure that in fact, should we ever get power in South Africa, that power should be compromised so that we are dead even before we are born.

I would like to underline that the scenario in Southern Africa is not just a group of white individuals clinging to power as long as it is possible.

But what they do is to make sure that even when that day comes when they lose their power - what we inherited is already compromised and rotten. We inherit problems rather than the freedom we have been sacrificing for. One of the areas that are being destroyed today and even in the future, is at what you may call the soft level of life. Not the hard things. You can see me if I have been killed, bleeding. You can see the 
buildings if they are bombed, they have collapsed. What you do not see is what is happening to my selfconfidence, to my manhood, to my religion. What type of children are we producing out of this system? Even when we overthrow apartheid - what type of people would we be dealing with in many cases - criminals.

South Africa is becoming the headquarters of crime. Crime is not going to be good after we have got our freedom. How do we stop our children in the street from being criminals? This is part of the killing I am talking about. The killing of the future, when South Africa becomes free, when Zimbabwe becomes free, when Namibia becomes free, and you get all types of crime taking place.

We often forget what we inherited from the powers that were yesterday. Precisely that extra bullet that makes sure that after independence, Mugabe must now have a population that has been criminalized, South Africa should be the same, Namibia should be the same, etc.

\section{THE ROLE OF RELIGION}

We have never had any real problem of religion and politics. Yes, we have been radical politically. Yes, we have been radical in terms of religion. Before any white man arrived to our continent they found us religious. I do not mean we were Christians. We were religious in a bigger meaning of that term. What we have found difficulty with, is when religion, in whatever description, was used as a tool to oppress, as a tool for injustice, for racism, for exploitation.

Hence, we have never come out to my knowledge, calling religion names, we have called certain people names, but not religion as such. In fact, it has been part and parcel of our struggle for a long time.

We therefore found it difficult when we went out of South Africa, and appealed to the international Christian world, because the type of religion that created a problem for us was Christianity. We thought: OK let's go to the headquarters abroad. And we did go to the headquarters. But we found it difficult to convince Christians at headquarters that something was wrong in South Africa, something was wrong in Rhodesia, something was wrong in pre-independence Mozambique and Angola. 
We found certain rationalisations. We found, that in fact, Christianity was being used to defend wrong practices of the colonial system and of the apartheid system. That is where our problems arose.

But still, even in the forefront of our struggles in Southern Africa we do have people from religious formations. We can give endless names of people who have sacrificed for that purpose yet they have been religious people. One could not say that all religious people were together conspiring against the peoples' interest in Southern Africa. But we are saying, institutions did, historically. And that is where the problem came.

\section{THE EGALITARIAN PLATFORM}

We in the ANC have been criticised, for instance for involving some of our compatriots, our brothers and sisters, who are classified as white people, or as Indians etc, in South Africa. "You are blacks, you should be the ones that are in the forefront in the struggle — not the whites" is what our critics say. Our argument has been simple. Apart from the fact that South Africa belongs to us all, our argument has also been this: I think we would be stupid to go and die alone to free South Africa and tomorrow ask the white to come and share that freedom. Frankly, we should all be there to die today so that we have justified reasons to call ourselves South Africans. I do not think whites should expect that they should come to live in London and just wait for me to die in order to get South Africa free and then say: Allow me to come back...

No, I think it is time that our compatriots are crosscolour, are crossreligious, are involving themselves in what is happening today.

One question posed in many quarters concerns the future of other race groups apart from those who are classified as blacks. What is going to happen to coloureds, what is going to happen to Indians, what is going to happen to whites? Minority rights! Somebody is shouting somewhere. From Washington. - Minority rights. Everywhere one could hear the word. At this point I have to repeat: There is only a question of individual rights, and most notably the right to be South African. It does not matter what colour. But in order to have that right you must have the same experience as all others are having — of fighting to free South Africa. We want total involvement of all South Africans 
across colour. That is the only way to make you entitled to call yourself a South African of tomorrow. The role of all the colour groups is that you go in and contribute to free South Africa. Then tomorrow we will not have a problem of racism.

\section{A GRAFTED CHURCH?}

The role of the church — what will it be? We hear: "You are going to be dictators. You are not going to allow this church, or that church, and all that!!" No, no, I think, as far as I can understand, the church has to do exactly the same thing as the people.

It must be there today, go down to the trenches with us. Be shot, be killed, be locked up, be tortured. Become refugees like all of us abroad. So that tomorrow, when we stand up on our political platforms we can say: Please, the church was with us. It is genuine and therefore it is entitled to operate freely in South Africa.

We do not want special rights for churches, because these would be rights grafted into the body-politics of that society. We want the church to be part and parcel of the body-politics.

I do not know if you understand. If I lose this tooth, the doctors tell me that I can not get a natural tooth so they graft an artificial tooth into me. I look nice, but it is not my tooth. Now, we do not want the church grafted into the body-politics in South Africa, we want the church to be part and parcel. We are not going to have special rights for football players. No, we are not. We are not going to have special rights for professors. We are not.

But, all formations, all people, would have the right to exercise what they would like to exercise, if they were there with us, today, to overthrow apartheid and contribute towards the reconstruction of a new society. It is very important.

Rather than sit comfortably somewhere, either as a professor, an academic, a researcher, a football player. Or in the Church, or in a mosque, or whatever formation, keeping on praying for us, or praising us or researching us. Writing big documents. Getting your Ph.D. on our struggle.

And when the day comes, they would come to us and say that they have been writing their dissertations on our struggle. I am allowed to 
come back. We would like all these people, all these organisations, all these structures to belong naturally, not to be grafted artificially.

When we ask: "What is the role of the Church in the future", we are already grafting. And I do not want that. Because no society is political, only. Or religious, only. Or economic, only. As a society it is everything. So, when we stop with the operations, today we graft economists, tomorrow professors, football players, rugby players. Where do we end? It is for the church to answer that question today, to us-where are you today. So, tomorrow, we can say-you are here. And you are entitled to be here.

We believe therefore, that the apartheid system has done a disservice to religion, by abusing religion for power. And we believe that enlightened religious practitioners today would help us to correct what apartheid has done, i.e. to create this artificial conflict between what is called politics and what is called religion. We believe that the two are closely integrated, almost inseparable.

\section{PRIORITIES NOW}

Your role is also that you contribute already to a better humanity after independence. We may know the problems, but we may not know all the answers. And we do not monopolise good thoughts. We benefit from the experience, knowledge and wisdom from all structures in society, including religious structures. And it is therefore the role for the churches to already give us the benefit of their experiences so that we can integrate it into our Freedom Charters, into our constitutional guidelines.

If you do not come now, do not say we did not include you in our constitutional guidelines. That is what I am trying to say. To contribute, to improve constitutional guidelines, to ensure that we do create a genuine alternative to apartheid.

And a genuine alternative to the lies, that have been told to people that there is democracy elsewere in the world but it is not working in Africa. We are finding it more and more difficult to find that in fact, there is democracy in many parts of the world. For what is practised? This issue is relevant when we look at the Church, too. At times it is not that individual little church in Durban or that Anglican church in 
Bloemfontein that really is the problem. That poor little minister with a suit which is old and poor is certainly not my problem. The problem may rather be what we call the Church International Incorporated.

That is the international syndicate of the religious activities that keep an eye on anybody in the world who touches the religious structures. When that happens they come pouring on you in the name of freedom of worship, and freedom of religion.

Nothing wrong in that, and I support protection of religious practices all over the world. But when I look closely, I find that in Latin America, the church has supported very funny types of governments - dictatorships. And yet they have closed their eyes to that.

We have internationally many very well organised religious structures. They are relevant to what is going to happen in South Africa. By their influence, the pressure they can exercise already today on their respective governments and also on South Africa. But they must come out. That is, the Pope in the Vatican must stand up and say that he does not like apartheid and instruct all the Catholics to say so, for better or worse. And I want the gentleman in Canterbury in Britain to say the same thing to the Anglicans all over the world. Come out, left and right. Similarly, the other denominations.

They must stand clear on the issue. Also to help the ordinary little small minister in my bushtown. Or the small believers who have no power.

The headquarters of international religious organisations must be helping the small little churches against whatever difficulties they have in order that those little churches in our part of the world can really identify themselves with people and therefore become relevant.

The ANC sees the relevance of religious activity. We do not discount that. But it is conditional. Otherwise it becomes meaningless. It becomes conditional on what the religious structures and institutions really do as opposed to what they say they would like to do.

\section{THE ANC AND THE FUTURE}

As regards the questions of the ANC future policies inside the country, I think we are unique, SWAPO and ANC, particularly the ANC, that we have already started to be asked questions as to the future and we are 
supposed to produce documents assuring what is going to happen. We do not have resources to do research, to bring people together, to think through some of these issues so that we can charter our way that effectively.

We have the struggle at two levels. It is the present struggle of survival of fighting the enemy of overthrowing apartheid. That is what is preoccupying us now. But already, questions are there, not just from the international community. Even more important, they come from the people at home. What does ANC offer in the place of apartheid? And those are heavy questions. We are trying to address them as best as we can.

We attempted this already as early as 1955 when we produced the Freedom Charter. Trying vaguely.to say that this is the type of future South Africa the people would like to see.

We have since then tried to come up with something more refined, a document called Constitutional Guidelines. We are still groping.

It is now being spread among our people at home and outside for comments, criticism and amendments and hopefully we would be able to finalise that document one day and be able to say that this is what the future South Africa will be like. It is a very difficult exercise but we are doing that.

My worry is that if we do not go ahead and lead that work on all fronts non-South Africans are going to tell us what South Africa should be. There is a lot of unemployment among academics all over the world. They are looking for jobs. You go to every city in Europe and America and they have seminars on something on the theme "what is going to happen after apartheid?".

Tomorrow we are going to quote them. According to Professor so and so South Africa should look like this. However, there is a danger here. I am worried. Because we might create a South Africa to suit other peoples' interests and not the basic needs of our people. What we have been laying our lives for, we will lose in the hands of academics, researchers, etc. I am worried.

We are in a dilemma. We do not have scholarships. Our children are in the streets. We are not getting scholarships. For good and bad reasons. We are in a dilemma. Some of our scholars are in prison in South Africa. We cannot use their brains.

You are in a dilemma, too. You have the resources and opportunities. 
How do we resolve that? So that the energies, the support you want to give becomes supportive of what we would like to achieve. Rather than we being a product of supporters that lead our struggle. I therefore plead: May our deliberations at this seminar be suggestive and supportive-in the right sense of the word. 


\section{In Commemoration of Soweto 1976}

Lisbet Palme

Tonight we have gathered to commemorate the hundreds of young people, who were murdered in Soweto by executioners from the racist South African regime June 16, 1976. The event stands as a symbol of the children's fight for a life in dignity. Children who want freedom and peace, who want to grow up in health and who want to have a school to attend. Children who have seen their closest family be humiliated, imprisoned, tortured and killed. Children who see their younger sisters and brothers succumb in the poor shelters in want of adequate food and health services. And all this is happening in a country with the most favourable conditions.

Nowhere else in the world are children's rights so crushed, so trodden under foot by the powerful as they are in racist South Africa, and in the entire region which has been destabilized by racist South Africa.

"Children on the Front Line" is the name of the UNICEF report about children who have been subjected to attack, torture and death - a report about how fields have been mined in Angola and Mozambique so that children are lamed and food production hindered, with hunger as the result. In Mozambique a quarter of a million children have lost their parents, and more than a third of health centres and schools have been destroyed, Millions of people are fleeing within and out of the country.

The continous up-dating of the publication "Children on the Front Line" is necessary to serve as an instrument for advocacy and development work. Namibia, on the doorstep to a free and post-apartheid society, is central in the edition this year. In many parts of the country education, health services and other social services need to be built up almost from scratch. When the children and the youth return from exile they will need to be taken care of and to become integrated into society. The upcoming election is of crucial importance for the reestablishment of the country.

The report is painful reading, but it should be read and read aloud. Nobody should be in a position to say that they did not know that 


\section{Lisbet Palme}

infant mortality rate in South Africa is 12 per 1,000 for the whites and up to 124 for other than whites or that 40 per cent of the children in the worst hit parts of the Southern Africa region die before they reach the age of five.

No one should be able to deny knowing that every three and a half minutes a small child dies in Angola and Mozambique because of war and destabilization nor that Robert Gersony in the United States government found it necessary to call the situation in Mozambique "one of the most brutal holocausts against the human condition since World War II".

Apartheid is a crime committed by a racist society which has legalized the murder of hundreds of thousands of children, left millions of children mentally and physically crippled for life, torn up families and sent them to a life in prison or exile.

Apartheid South Africa denies the neighbour-countries to benefit from what has been built up under great sacrifice, and with the support from the donor community. Some of the children in Mozambique have drawn pictures and written about massacres, mutilations, bodies cut into pieces - horrors which they themselves have witnessed. With deep respect I want to quote one of the children, 11 years old, who says:

The armed bandits massacre our mothers, our fathers, grandparents and brothers. At the countryside people do not dare to stay and work in the fields because the bandits attack the villages and steal everything. We beg the whole world to help us bring this situation to an end.

The real meaning of warfare and destabilization is that, every year in Angola and Mozambique an additional 150,000 children die before the age of five. In Mozambique, 8,000 children have been dragged away from their families, brutalized, instrumentalized and horror-ridden for life in case they survive.

I have travelled several times to Africa, what I have witnessed is unbearable and beyond understanding.

Last year when I visited Mozambique, I listened to Mozambican leaders, who shared their reality with me. I was impressed and moved by the dignity these sorely tried people showed in their concern to help the children.

But how can these children restore their human dignity, they who have been forced to go with the bandits, to perform beastly acts as 
killing their own mother or father, their own sister or brother? Is there any future for empty-eyed little girls who have been raped and abused by the bandits?

Where is the hope for the children of Southern Africa? Where is their future? My husband, Olof Palme, made a speach one week before he was himself murdered by violence. He had chosen to speak very pragmatically about what apartheid really is and, also very pragmatically, about what we are doing. And then he said:

Fundamentally this is a profoundly emotional question and one which goes to the depths of our feeling because it is such an uncommonly repugnant system. Simply because, on account of people's colour, it abandons them to poverty. This system will be to the discredit of the world for as long as it persists.

But when expressing these feelings it is important for us to remember the very simple, basic facts which I have presented. And we know that we have a duty, knowing as we do that this system is sustained by the internal apparatus of oppression, the entire police force, the military and this wretched complex of legislation making up the apartheid system. This is why they are still able to put their opponent's leaders in prison.

And he continued:

That was one point. The other is that this system cannot, would not be able to survive if it were not, in various ways supported or accepted or tolerated by the rest of the world.

And he finished by saying:

$\mathrm{O} n$ the one hand we have the apparatus of oppression, which is undermining itself and is being undermined by the courageous struggle waged by the black popular movements in South Africa. The other is outside support, and so by declaring our support for the black struggle, and by helping to isolate the apartheid regime, we must live up to our responsibility for bringing this repulsive system to an end.

In the Nordic countries we have decided on mandatory, comprehensive sanctions against racist South Africa. In the Security Council of the United Nations France and West Germany abstained and Great Britain and the United States voted against.

And meanwhile children are exposed day after day to violence and atrocity. Some have listened to how children themselves have experienced their tremendous sufferings. The Norwegian child psychologist 
Magne Raundalen has let children draw and describe the war and violence in their lives. $\mathrm{He}$ and his collaborators describe different patterns in the ways in which children coped with their dreadful situation. One group is represented by children who fled from their villages, when they were attacked. Having no family and no shelter they joined the guerilla movement and were trained as soldiers. The psychologists, when they talked to them clearly felt the impact of military training. Child soldiers were also said to be more brutal and less hesitant in using violence than adults. The psychologists also found that aggression and violent acts could easily be "used as a drug to cure grief from loss and lack of hope for the future.

But the children who got help from various organizations showed a different pattern. These children's description of war and violence are not at all characterized by hate, violence and revenge. They did not write about an identified enemy. The enemy was the war, the violence. Asked about their prospects for the future they said that they wanted to become nurses, doctors, drivers and relief workers. They expressed identification with the people who were doing good, not with the aggressors.

If children get a chance to identify with decent people, who care about others, they too care. Oppression, war and armament must be changed into freedom, peace and development if the children are to have a future. This is true of children of Southern Africa, but it is also true of our own children. Our children perceive and comprehend that the children of Southern Africa are suffering. More adults must shoulder the responsibility for the positive development for the children to trust society. This is crucial for the evolution of the future because the children bear the future within them. 


\section{"In Humble Submission to Almighty God' - Church, State and Conflict in South Africa}

Sheena Duncan

The State in South Africa has made the Christian church central to public affairs. Whether or not the church will prove to be central in the struggle for justice and peace has yet to be demonstrated. However, it should be in a country where more than $75 \%$ of the population claims to be Christian, where the churches are full on Sundays, where the State actively promotes an evangelical fundamentalism, and where the political aspirations of the people are so often expressed in words taken from biblical teaching about justice for the poor and the oppressed.

But the church reflects the multiplicity of the divisions in the society from Dr Truernicht's position: "The diversity of peoples is in accordance with the will of God... I would say that taking measures to protect your specific identity would be justified"... to our belief that: "We who are many are one body for we all partake of the one bread."

\section{A CRITICAL LOOK AT THE CHURCH}

The Church in South Africa is not of one mind in the political conflict. We all confess that the church's one foundation is Jesus Christ her Lord but we are divided in our interpretations of what that means.

The Catholic church and the member churches of the South African Council of Churches are certain at leadership levels and in the majority of congregations that apartheid is a fundamental denial of the lordship of Jesus Christ but within each denomination there are those who challenge this. The conflict is creating tensions between black and white Christians, between rich and poor Christians, between the haves and the have-nots in the Christian community.

These churches are not united behind the prophetic teaching of their 
church leaders let alone behind the political demands made by the church leaders.

The white Dutch Reformed Church is institutionally supportive of the present government. It has often been described as the National Party at prayer.

Yet it is from within this church and its sister churches that some of the most courageous and important opposition to apartheid is coming - from the white as well as the black congregations.

Among the African Independent Churches are those who are in the forefront of the struggle for liberation as well as those for whom existing authority is never to be challenged - not to mention that curious pair of Bishops who constantly appear on your television screens as they tour Europe as the "leaders of five million Christians". We are still looking for their millions.

We must also take note of the rapid growth of the "right wing religious" in Southern Africa preaching a prosperity gospel rooted in the teachings of TV evangelists in the United States but also echoing the conservative evangelicals here in Europe - preachers whose gospel seems to have more in common with the British Prime Minister's pronouncements than it does with what is written in the New Testament.

Their interpretations of Christian belief is being effectively used by our rulers to reinforce the strategies of military control.

These are the reasons why the sub-title to this address is Church, State and Conflict rather than Church/State conflict. There is conflict between the churches belonging to the South African Council of Churches (SACC) with the Southern African Catholic Bishops' Conference (SABC), and the State but it is also the case that there is conflict within the churches regarding the political struggle and the impossibility of having peace without justice.

Our Assemblies, Conferences and Synods pass many resolutions condemning apartheid in all its facets. Theologicans declare our government to be illegitimate. Church leaders prophesy and try to lead us into action but we remain inert.

We are burdened with the ancient structures and processes inherited from the European history of colonial expansion--structures which can be, and are, used by the fearful and the uncertain to prevent action and to render it ineffective. 
Yet the church is truly in the struggle - taken into the frontline by the tens of thousands of believers who are striving to win justice in all the progressive secular political, worker and student organisations. They have not been crushed by three years of State of Emergency or the many decades of brutal oppression which preceded it. They have left the institutional church far behind because they do theology instead of just studying it. They are the church.

Perhaps it is impossible in Africa to make any sharp distinction about what is secular and what is religious. Religion and daily life are inextricably interwined. Almost all our political meetings begin and end with prayer. Ministers of religion are almost always part of the group on the platform, and this includes many trade union meetings. Our national anthem is a hymn.

We of Africa wonder rather when we come to Europe or North America to find that not even church meetings always begin with prayer. We are not yet in the post-Christian era in South Africa.

So what of the South African State in which this part of the church finds itself? We are at the beginning of a process which is to lead us in the end to defining priorities and the continuing challenge to the church in the South African struggle.

\section{SOUTH AFRICA AND THE WORLD'S AGENDA}

Before I came to Uppsala I had been enjoying a long family holiday in Britain. This has revealed to me how very difficult it is for our partners in places outside Southern Africa to understand the complexities of our situation and to measure the meaning of events. For example, what will it mean if Mr Mandela is released after the general election on 6th September? Does it mean the beginning of the end of apartheid? Would it justify the lifting of sanctions or a visit by Mrs Thatcher to Pretoria?

I believe the answer to both these questions is "no" but it will take me time to explain why. It is impossible for newspaper, radio and TV correspondents to present in a small space all the "ifs" and "buts" and explanations and qualifications necessary for understanding what it will mean and what it will not mean.

I have also come to understand that Southern Africa for you has to be just one of many concerns about the human suffering in this world of 
ours. The images of the struggle in China on the TV screens of Europe have had so many parallels to our struggle. There were the young people, unarmed and dedicated to democracy. There were the bureaucrats, the machinery of the State grinding on. There were the power struggles within the ruling party. There were the restrictions on the media and the antagonism towards foreign correspondents. There was the brutality of the guns - the indiscriminate shootings, the confusion, the disappeared ones. There were the dead and the terrified.

When we commemorate Soweto we must also remember those others who have died in the same struggle for justice and democracy and peace in other places.

I have experienced the same difficulty in understanding events in China as you must experience in understanding what is happening in South Africa. The drama is there on the TV screen but one has to search for the meaning in the written word in specialist publications so perhaps my task this morning must be to try to explain what the contemporary version of apartheid is and to try to highlight some pointers which will enable you to measure whether apartheid is going and whether injustice will also disappear with apartheid.

\section{THE EMERGENCY AND RESISTANCE}

Last week the State of Emergency in South Africa was renewed by President Botha. He said this was necessary "to safeguard the due democratic process in the coming parliamentary election".

I don't think any of us have been surprised by the move. Once despotic governments have experienced the power they can wield if they have power to detain persons indefinitely without trial, to ban persons and organisations, to ban meetings and restrict funerals, to prevent the media from reporting on events, to remove completely the protection of the Courts of law, they will not lightly relinquish these powers,

In South Africa more than 50,000 people were taken into detention between the partial State of Emergency of 1985 and the end of the third year of total national State of Emergency last week. Over one quarter of these have been young people, many of them children under the age of 18. Approximately 5,000 of them have been women. 
And yet in all this there has been hope and what has proved to be successful resistance. In the early months of this year long-term detainees undertook sustained hunger strikes supported by their families and friends on the outside and by church leaders.

Altogether 630 detainees were released in the first three months of 1989. The Human Rights Commission has a sample of 503 people from this group: 17 of them were already in detention when the national State of Emergency was declared in June 1986-30 months in prison without due legal process, 122 of them had been held for a full two years, 79 of them had been detained during 1987 and were into their second year inside. The remaining 248 had been detained during 1988.

The majority of those released from detention following the hunger strike have been served with restriction orders. These orders often impose very severe house arrest conditions and prevent many of the banned persons from resuming their employment, often severely hampering the work of the organisations they belong to.

Most of these restrictions have been re-imposed this week in terms of the renewed Emergency and will remain in force until the current Emergency is lifted or expires in another year. They can then, of course, be re-imposed in any new emergency declared in 1990. Ways of defeating this particular means of repression are being thought about and I have no doubt will be found.

Perhaps Mr Pik Botha, our Foreign Minister, should take note. He was quoted in Britain last week as saying of the crisis in China: "These events bear testimony to the resistance that builds up within such an authoritarian system."

The Free the Children campaign is another example of the way in which the people can impose restraints on our government. The power of non-cooperation, civil disobedience, exposure and publicity is well understood and there is no evidence that the government can control non-violent direct action of the Gandhian kind. Children are no longer being held in detention in the large numbers reported in 1986 and 1987. I wish we could be certain that no person under the age of 18 (the legal definition of a child in South Africa) is currently in detention but the widespread protest inside South Africa and internationally about the detention of children has been largely successful. (Footnote: In the first week of October 1989 it was reported that two fourteen year olds were known to be in detention.) 
We need to note that the South African government is vulnerable to international pressure. We want to be part of the western world, we cannot stand international isolation and opprobrium, and our economy cannot withstand the threat of further economic sanctions.

The lifting of the State of Emergency is one of the basic demands of the opposition groups inside South Africa. There can be no progress towards the transformation of our society without this but we must be mindful that the State of Emergency is not in itself the key factor in the S.A. government's control over opposition. The Internal Security Act gives the State the power to detain the government's opponents indefinitely and it has been used to do so ever since indefinite detention became part of "normal" law with the passing of the Terrorism Act in 1967.

Even without the Emergency Regulations the State has the power to ban persons and organisations, to hold people in detention for unlimited periods, to control the press, to deny freedom of association and assembly. In the 25 years following 1963 a total of 21,863 people were detained in terms of this legislation. It was in terms of existing security laws that 19 organisations were banned in October 1977 together with two newspapers.

It is no longer remembered that the total ban on all outdoor gatherings - a gathering is more than one person - has nothing to do with the State of Emergency but was imposed at the time of the Soweto disturbances in 1976 and has been renewed annually ever since.

\section{A MOVE AWAY FROM APARTHEID?}

So if the State of Emergency is lifted it will not necessarily signify a move away from apartheid or a relaxation of the Government's determination to maintain control. It will be a welcome move but must not be misinterpreted by the outside world nor should it be rewarded by any extraordinary signs of friendliness by western governments.

I strongly believe that visits to South Africa by heads of States would be premature and damaging to our long term interests were they to take place before the basic demands are met - the release of political prisoners, the unbanning of all banned organisations and persons, and the free return of exiles. Only then might we be able to believe that a process 
towards a just and democratic future can begin.

I do not want to dwell too long on these aspects of repression because they are well known but mention has to be made of the growing incidence of political assassination, the disappearance of political activists whose bodies are never found, and the unsolved crimes of violence against the premises of political organisations. The killing of David Webster outside his house on a peaceful Monday morning, on May 1st this year, was another in a long line of such unsolved murders. The destruction of Cosatu House by a bomb in 1987, the bombing of Khotso House, headquarters of the SACC, in August 1988, the burning of Khanya House, headquarters of the Southern African Catholic Bishops' Conference in October, the destruction of the Black Sash office in Port Elizabeth in the same month, join a long list of attacks by bombs or fires on the offices, equipment and records of opposition organisations, including trade unions.

Because these crimes are almost never solved it is impossible to know by whom they are perpetrated, but one can ask in whose interests it is to remove significant leaders from the opposition spectrum, to disrupt the work of organisations opposed to apartheid, to try to frighten political activists by the killing of their friends and colleagues. In whose interests would it have been had Frank Chikane died in the recent attempt to poison him which came so near to succeeding?

These attacks are part of a coherent pattern. They are well planned and skilfully executed. They cannot be seen as isolated expressions of spontaneous right wing hatred and anger.

Nor must we forget the use of vigilantes in local communities to beat and terrorise people into submission. The violence and killings involved in these conflicts have been very skilfully presented to you "as black on black violence".

These are the various means used to maintain the National Party in power and to maintain the fundamentals of the apartheid system.

\section{WHAT APARTHEID IS}

We have to understand what apartheid is. Over the last forty years world attention has been caught by its most degrading and blatantly racist manifestations - park benches marked "whites only", the exclu- 
sion of black people from theatres, cinemas, sportsgrounds; the separate queues in public offices, the pass laws, and so on. Now these things have largely disappeared.

Tourists come to visit us in ever increasing numbers bringing with them large amounts of foreign currency and taking home again a powerful political message: "Apartheid is dead."

They tell you that there were black people in the hotels they stayed in, the restaurants where they ate, on the beaches, on the sportsfields, and in the audiences at sporting events, theatres and cinemas. They may even have gone on bus tours around the townships, been shown the new modern three-bedroomed houses which are being built with one and a half bathrooms, garages and burglar bars. They will tell you that economic development is destroying apartheid.

They have seen all these things. They are telling you the truth as they have seen it. They have not, however, seen the 6 million homeless people (one in every six South Africans is without adequate shelter), the millions of people who are becoming increasingly impoverished as the few get richer, the landless, hopeless people in the homelands and black urban ghettos, the over-crowded ill-equipped schools and hospitals, the migrant workers in their hostels, the exploited workers in the deregulated, decentralised factories and shops in the wealthy cities as well as on the homeland fringes.

They have not met the people in the communities still threatened with removal nor those who have been, or are about to be, incorporated into a homeland against their will. They will not see these things unless they come with the serious intention to find out and to forego the beautiful beaches, mountain resorts, game parks and casinos. They will not find the poor, nor can they find the truth, in those places.

\section{A PROCESS OF REFORM?}

The reform era since P.W. Botha came to power in 1978 has produced far-reaching social changes which have not been entirely cosmetic. Many have been significant and their consequences are of great import but we have to understand them as being necessary to the maintenance of white power.

After the growth of worker organisation from the early seventies and 
the resurgence of black organised opposition in the black consciousness movement from the late sixties; after the educational crisis of the midseventies and the world-wide revulsion at the killing of children in Soweto in 1976, the government was faced with a black resistance which would not be easily put down because it was deeply rooted in communities. It was also faced with pressure from the white business community which was urging that reforms be implemented to restore stability and that steps be taken to ensure that economic growth be speeded up by providing the necessary educational skills and training to break the bottle necks caused by lack of skilled labour. Big business needed a stable, non-migrant, skilled labour force with the ability to reproduce itself. Big business needed regulation of the now organised labour force. It needed freedom of movement. It needed the kind of stability and security which would encourage foreign investment.

Hence came the private sector's investment in housing, education, pension funds, pressure from the business community for the repeal of the pass laws, for social reform, for an end to job reservation and so on. Government gave way to these pressures because it had no option.

The reform process has been described as a process of deracialisation and re-racialisation. That is an accurate assessment.

There has been a deracialisation in the social sphere. Indeed I think I have heard more blatant racism expressed in Britain this year than I have heard in the last ten years at home. The Monday Club's statement last week that "we should not become the dustbin of Europe. These people in Hong Kong are not British, they are Chinese" is breathtaking but is just one example. It is normal to use the term "non-white" in Britain which we outgrew long ago. Such language is no longer fashionable in government circles in South Africa. Even spokesmen for the Conservative Party use terms such as "group identity", "cultural identity" rather than racial descriptions. Our Foreign Minister meant it when he said that he was not prepared to die for a sign in a lift.

Likewise across the whole spectrum of anti-apartheid opposition in South Africa the demand is for "non-racialism" and not for "multiracialism" which is now the declared government aim.

Multi-racialism is possible within the confines of the apartheid structures because it implies the preservation and structural recognition of racial identity as the prime factor. Non-racialism challenges apartheid because it denies racial identity as the defining factor of group interests. 
At the same time as de-racialisation has been undertaken there has been re-racialisation which has been the political process which has entrenched apartheid in the South African constitutional system for the first time and which is extending the concept of racial definition at all levels of government and administration. There is more apartheid now than there was in 1978.

So, what is apartheid?

\section{THE FOUNDATION OF APARTHEID}

I define it as an elaborate, expensive and wholly evil system designed for the maintenance of power in the hands of the ruling white minority.

The "reform" process is as necessary to the maintenance of that power as is the system of repression.

The foundation law of the whole apartheid system is the Population Registration Act, otherwise known as the Race Classification Act. This act requires that all people resident in South Africa be classified according to their race. There are two main groups - the black group and the white group. Those who are not white or black are classified as coloured. The coloured group is further classified into categories such as asian, malay, cape coloured, other coloured. The black group is subclassified into 9 different language and ethnic groups. Only the white group is monolithic and is not further classified into language or cultural sub-groups. Thus is created the false claim that South Africa is a nation of many different national minorities.

It is on this law that all other apartheid laws are based-the Group Areas Act, the educational, health and welfare system, the constitutional, governing and administrative structures. If this law is repealed you will know that apartheid is dead.

But, we in the churches need to remember the need for caution. Apartheid may die but oppression may continue. It is quite possible that there will come about a coalition of authoritarians with governing systems designed for the preservation for power in the hands of the Haves. In this lies the importance of the gospel message about justice and peace.

It is for the poor and the oppressed that the weight of our concern must lie. 


\section{IF APARTHEID GOES. .}

If apartheid goes we could well become merely another one in the majority of the world's nations where power is not held by the people, where wealth is the criterion of merit and where merit decides power. Even here in Europe there are tendencies towards this reversion and denial of justice and democracy.

The church must answer Dr Weber's question: "What are we to do in societies where merit rather than grace is the defining factor?"

It is a sign of hope that such questions are now being raised in South Africa and in the exiled movements. There is recognition that the struggle for justice and peace will go with us into the post-apartheid future.

Political power is the control of the national wealth. In South Africa this power is entrenched in the hands of the white minority through the complicated structures of a constitutional system incredible in its elaborate processes.

There are fourteen different governments whose jurisdictions are defined by phantom geographical borders in the case of the ten homelands and by race in the case of the three houses of the tricameral Parliament and the "general affairs" cabinet which retains the control of what money is made available to all the other legislatures.

Fourteen is just the base number. In the case of social pensions, for example, there are 18 different authorities - the ten homeland governments, the three houses of the tricameral, the four Provincial administrations dealing with the payment of pensions to black people outside the homelands and the overall "general affairs" government which decides just how much money each authority will be allocated for the payment of pensions.

The homeland governments and the three racially defined houses of the Parliament each have legislative as well as administrative powers over the affairs of their own racial or ethnic groups but, except for the white house of the Parliament which effectively controls the "general affairs" structure, they have no power to decide their priorities and to execute them because they have no control over the share of the national budget which will be allocated to them.

Far from showing any signs of moving away from this concept, the white government is planning to institute regional black legislatures, 
possibly nine of them, to deal with the affairs of black people living outside the homeland borders. The legislation is drafted. It remains to be seen whether it will be implemented or if a post-election government will realise the impossibility.

This structure of government extends down to the local level where the hundreds of different racially defined local authorities are elected to rule over municipal areas defined by race. The local authorities have responsibility for the provision of resources and orderly government within their own areas but have no control over the provision of finance to do this efficiently. The wealth lies in the white controlled central business districts. Regional Services Councils have been established to control the provisions of bulk services on a regional basis. All local authorities have representation on these Councils but the voting power is heavily weighted to ensure that the decision as to how money will be allocated remains in white hands. Voting power is decided by consumption of service and of course the white municipal areas will always consume more electricity and more water given the fact that many black townships have no electricity and only rudimentary water supplies, and the industrial townships and commercial centres are in the white areas.

Mr de Klerk has not said one thing which leads us to expect that he will voluntarily move away from this concept. He talks of multi-racial consultation and remains firmly committed to the group idea. If he is to introduce real change he will need to be pushed.

Parallel of this constitutional structure there has been another system of government which operates more or less in the dark and which has been brought into the very centre of political decision making by P.W. Botha in his years as President.

The National Security Management System is implemented through the State Security Council at Presidential level with its Regional Management Centres and literally hundreds of Joint Management Committees at local level with their sub-groups and mini-groups. The military and police are dominant partners in all these structures which have been set up to implement the military strategy for maintaining control.

This strategy has been described by the security forces as follows: 
Step 1. Pacification or sterilisation, i.e. the State of Emergency and the various mechanisms of repression described above;

Step 2. Addressing the grievances of the people, i.e. the "reform" measures described above;

Step 3. Instituting orderly government, i.e. the process of introducing and extending the constitutional structures of government described above at all levels of societal organisation.

Mr de Klerk's conservatism may well lead to the removal of the military from its current central position in the structures of power and to the restoration of power to the Cabinet and decision making to the political structures. There have already been indications of this with the decision that hunger strikers should be released from detention. There have been press reports that this was the first time in three years that the Cabinet had overruled a decision of the Security Council.

If this is the case it is most welcome.

\section{SIGNS OF HOPE}

There are many signs of hope in the current situation.

Developments in white politics with the formation of the Democratic Party and the "fourth force" within Afrikanerdom which sees the best hope for the survival of the white group in negotiation of a democratic future will prove to be important even though the major forces for change lie elsewhere. It is significant that the Law Commission's report on a Bill of Human Rights for South Africa has rejected the concept of group rights and suggests a process which needs to be undertaken if such a Bill of Rights is going to be meaningful. This process would include a declaration of intent on the part of the government, the repeal of laws which would be in conflict with the Bill if it were to be adopted, a public education and discussion programme followed by a referendum of all adults. All these things would have to precede the adoption of a Bill of Rights. Government response has been negligible but this is a powerful document even if some of the details are arguable.

There is a growth of a human rights culture in South Africa at the 
moment, the best example of which is the campaign to end the death penalty. In the black community this is no longer just a demand for the lives of those sentenced for political offences but for total abolition. The growth of this movement has been astonishingly rapid.

There is hope in the recognition of the power of non-violent direct action and civil disobedience with various forms of non-cooperation.

We have hope. We know that our rulers only have as much power as we choose to cede to them. The struggle will be won by the way we act inside South Africa but pressure from the international community and the support and concern of the Church in other places is very important to us.

The road ahead is not a smooth one but at least there is a road and the people of South Africa are marching steadily along it towards a future in which maybe we can establish that just, non-racial democratic society we all long for. 


\section{Has Apartheid Gone?}

Axel Ivar Berglund

\section{AFRIKANER NATIONALISM}

In 1949 South African government power shifted from the United Party under the leadership of General Jan Christiaan Smuts (known for his warm British links) to the Nationalist Party and its deeply rooted concerns for Afrikanerdom. The following diagram illustrates the distribution of power as from 1949, a structure that in general describes the first 30 years of Nationalist government:

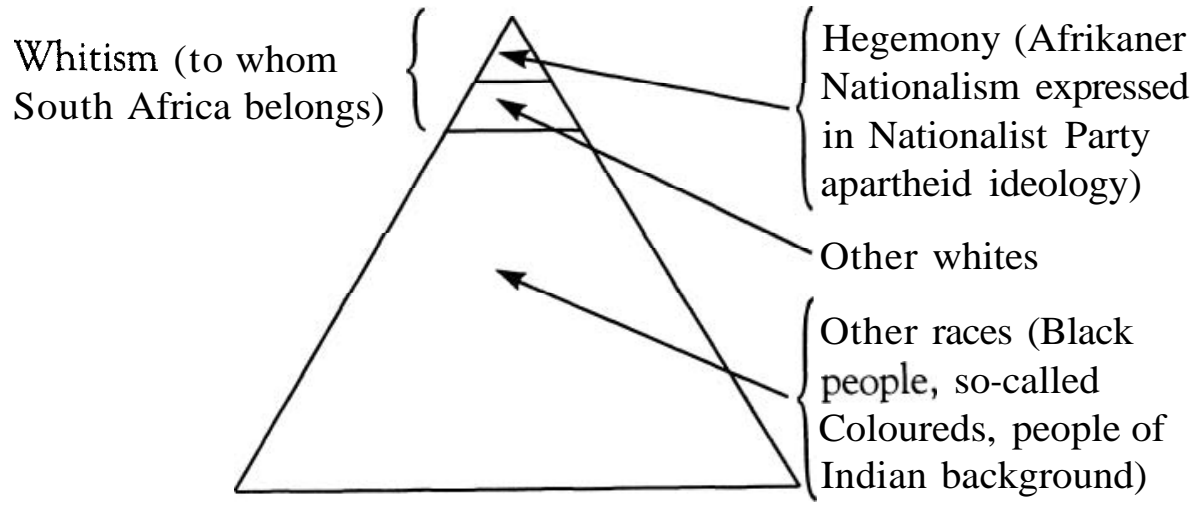

Since taking power in 1949, the ruling Nationalist Party has done basically two things:

(a) with vigorous energy and great determination applied apartheid and its goals into all walks of life in South Africa. No costs have been too high; no opposition even an uncomfortable hindrance; no morals or ethics the reason for a visibly bad conscience. Such has been the conviction and determination that nothing whatsoever has been allowed to come and remain in the way of implementing the ideology. If a hindrance of any kind did not of itself withdraw or change its course, it was removed - and removed with no waste 
of time. Legislation, money, brainwashing, brutal power, these and many more have been the tools used to achieve what was wanted.

(b) Afrikaner Nationalism has shrewdly adjusted to national and international criticism. For it stands to reason that an ideology such as that represented by apartheid cannot be applied without opposition.

The South African government's present course of action, expressed chiefly in so-called reforms, is a response to developments in the mid 1970 's and subsequent years. The Soweto uprisings on the 16th of June 1976 which placed South Africa squarely on the world map was the major national event of the decade. Less dramatic but with considerable force was the rapid development of local opposition groups, these to some extent being inspired and motivated by the independence of neighbouring countries (Mozambique and Angola followed by Zimbabwe). National and international reactions were such that after the early 1970's the South African economy was unable to develop consistently.

Despite a liberalization of the rigid ideological structures with regard to apartheid which the new 1984 constitution may seem to indicate, coupled with generous terminology such as "apartheid has gone", "we are in the process of reform", etc., there is nothing that convincingly suggests an ideological change. The intention of the claimed reforms seems to be an avoidance of offensive terms and repugnant public features of the ideology rather than a move towards bringing about fundamental change.

The 1984 constitution has included so-called Coloureds and folk of Asian background on the voters' rolls but not as a move towards shared power. Instead, the aim appears to be to increase the stability of the government, and acts as an answer to and pacification of people for whom a so-called Homeland situation could not be constructed (note: the two so-called Coloureds and one Asian in parliamentary seats against the four whites, securing white domination under all circumstances).

The new constitution has also paved the way for executive powers to lie in the hands of the State President and appointed committees. This has been made possible by way of the vicious and secretive National Security Management System, which undermines both efficiently and 
yet shrewdly the role of a parliamentary system of government. It is beyond doubt that this style of rule has been designed to provide powerful mechanisms for action against any threats that may arise. It is a pragmatic adaptation to strengthen the Government's own power position in the upholding of apartheid.

This Nationalist Party policy as emerging in the 1984 constitution can be illustrated thus:

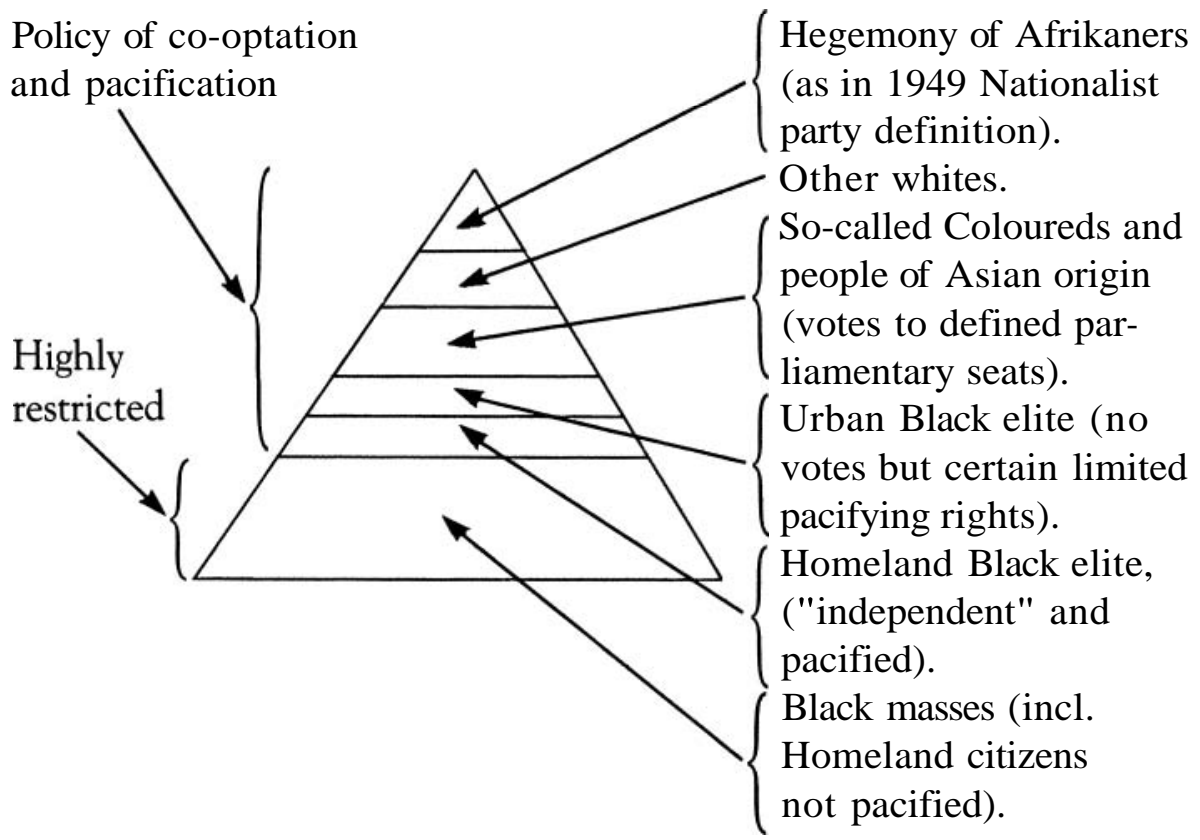

\section{THE CONSTITUTIONAL CLAIMS}

The implementation of the apartheid ideology in South Africa depended heavily on legislative measures, particularly in the period 1949-1976. Seven main pillars carried the system, with a large number of other precautionary and supportive measures naturally also playing an important role in the total set-up.

1. The various Land Acts had as a starting point the 1913 legislation, which was followed by the 1936 Act passed by the Smuts United Party. The basic point of departure, namely that South Africa is 
primarily the white man's country and hence the need to restrict land ownership possibilities in order to avoid black possession of it, is illustrated in these Acts. With the Nationalist Party in power, land ownership issues were articulated further and subsequently developed into the Homeland policies.

2. The Population Registration Act of 1948, one of the first and primary concerns of the Nationalist Party, determines (i) the franchise, (ii) economic and social benefits payable by the state, and (iii) people's mobility. Coupled with the creation of "independent" Homelands, the Act has removed birth-rights in the Republic, normal access to work, travel opportunities and social benefits from a great number of Black people.

3. The Group Areas Act of 1950 implied a socio-economic steering of particularly Black people. It determined residence, possibilities to own property and land, movement and citizenship.

4. The Homeland and Citizenship Act, 1970, made possible the 10 planned Homelands, ethnically diversified. As an extension of the Land Acts, this particular act has emerged as the outstanding landmark in the division of the country, diversified citizenship and stringently restricted possibilities to own land. The practical implementation of the Homeland policy is well known; Homelands cover 13.6 per cent of South Africa distributed in a large number of "islands" and set aside for Black people (Black people are about 80 per cent of the total South African population). $83.4 \%$ of the land is reserved for whites, so-called Coloureds and folk of Indian background.

5. The Suppression of Communism Act, 1955, addressed itself both to an anti-capitalistic economy and to leftist orientated opposition. In South Africa there is very real fear of communism in the white sector. To be accused of being an adherant of Communism has farreaching consequences.

6. The Influx Control Act and Urban Access Act, 1945, determined chiefly the urbanization of Black peoples in their search for work. Labour was to be on a contract basis with the labourer's home preferably in a rural situation to which he would return on the occasion of the annual holiday or on termination of the contract.

7. The Bantu Education Act, 1955, was Hendrik Verwoerds breakthrough as a political genius. He masterminded the Act on the 
assumption that Black people were incompetent to undergo scientific schooling. Black peoples education was to be set at a level decided upon by authorities who knew what they were capable of achieving "in accordance with their own culture"!

The seven pillars contained and expressed an offensive and repugnant attitude. In a great many cases their practical implementation was equally repulsive. With time both internal and external pressures against the vulgar abominations of the apartheid ideology and its practical application have gathered momentum. With growing worldwide opposition the need for adaptive and imaginative response became increasingly necessary. In the process of abandoning the offensive and objectionable, yet with determination to retain power, a known but undefined pillar to support and uphold the structure emerged. Secretive, very powerful and highly efficient, it is the Internal Security Act of 1982 that today is the carrier and far-reaching force that upholds the power structure of apartheid. With the Act as formidable resource and security, "the total onslaught" of South Africa's enemy can be met by way of a "total strategy".

"Total strategy" includes the abandonment of "petty apartheid" repulsive language/terminology/attitudes, and certain legislation. It introduces a policy of co-optation, implying voting privileges for Coloureds and Asians, as well as the emergence of a voiceless pacified middle-class Black elite.

The Internal Security Act of 1982, however, has led to a qualified and entrenched apartheid in the country's 1984 constitution. With its goals hidden in subtle language and outwardly seen to be addressing itself to reform, it is important to bear in mind the fundamental belief which binds Afrikanerdom together, namely that South Africa is a white man's land. Hence the concentration of power to those who at all costs will defend and adhere to the ideology of apartheid. It is noteworthy that Black people are mentioned only once in the 1984 constitution - they do not belong to South Africa. Yet the State President has the prerogative to rule Black people at will and his overall powers are little short of dictatorship. For all practical purposes the State President controls virtually everything by way of the centralization of power and has, constitutionally, probably more power than any other head of state elsewhere in the world. 


\section{AND BEYOND}

It is true that certain elements of apartheid have been abolished in recent years. Some of the removed elements have been significant expressions of apartheid. Their removal cannot be dismissed as mere window-dressing or cosmetics. But it is equally true that as some screws of apartheid are being loosened, the screws of authoritarianism are being tightened. The state of emergency and the vast, sweeping powers given the police and military speak their own language. In the process of allowing some (and possibly the majority) of the former pillars of apartheid to wither away, there is reason to believe that the statutory matrix of the ideology, the Population Registration Act, will be neither repealed nor allowed to be forgotten. Supported by the massive Internal Security Act it will indeed alone uphold the ideology and in the process entrench apartheid. The Internal Security Act and the overwhelming battery of security legislation, including the present state of emergency, do not primarily seem to have the maintenance of law and order as purpose: the real aim is to store up domination and power.

What does appear to be quite evident is that the state of emergency has created a false sense of security in the government, among its supporters and on the international scene. In the first 11 months of 1988 South Africa had a net gain of 2,340 residents, compared with a loss of 3,395 during the same period of 1987 . Repeatedly the government has claimed that the situation is under control and that unrest has ended. In the meantime hundreds of people are being killed in vicious unrest throughout the country. While avoiding to address the core of the problem and even in the long term presenting no solution other than increased suppression, one cannot other than conclude that the Southern African authorities ultimately choose to face the inevitable, violent confrontation in open war.

Despite a very marked urbanization among Black people in South Africa and the rapid industrialization of the country, processes which have left deep and clear marks on both the individual and on society, Black South Africans have been able to retain much of their traditional dignity and to approach life. It is these truly African and dignified presuppositions that time and again make deep impressions and offer a sense of optimism even when no ray of hope can be seen. For, humanly speaking, the future of South Africa does appear to be dark and risk 
heavy bloodshed.

However, there is no time for despair. "Ubuntu", a word common in Bantu languages, implies human-ness and a humane concern for others. The word includes human dignity and a sense of worthiness. "Ubuntu" has retained a remarkable forcefulness and strength in all Black communities, despite extreme poverty, forced labour, mass removals and many legalized forms of humiliation. A black lady of considerable influence said: "We know that also they (i.e. the whites) have 'ubuntu' although they rarely show it. They are too afraid to show it to us because they think we do not know of it (i.e. 'ubuntu')." Laugh! "But when we are free we will show them what 'ubuntu' is and let them feel free to show us 'ubuntu' also." Indeed, what hope this statement contains! 


\section{Namibia - a Sign of Hope}

Jose' Chipenda

We wish to thank the Scandinavian Institute of African Studies and the Nordic Institute of Missionary and Ecumenical Research for having invited us to participate in this conference on "Religion and Politics in Southern Africa". In the name of the All Africa Conference of Churches which comprises 141 Member Churches and National Christian Councils, we wish to convey to you the warm greetings of the Governing Body and very specially the Presidium headed by our President and Chairman of the General Committee, the Archbishop of Cape Town, Desmond Tutu. We wish you all good health, long life and disposition to continue fighting for justice and peace at home and abroad.

We know how much you are doing to support the struggle of the oppressed masses in Southern Africa and how committed you are to the Southern Africa Development Coordinating Conference. We in the All Africa Conference of Churches, are grateful to you for the moral and material support we receive from your churches to carry on our many activities which include: assistance to refugees and people affected by the rampant violation of human rights in many of our countries; mobilisation of women and youth to actively participate in the life of our church and society; involvement with churches and nonchurch groups in the development of human and natural resources. Together with all other organisations, the All Africa Conference of Churches is committed to work for peace and justice in Africa and abroad. It is our conviction that God has called us to be His witnesses. We are called to Rise and Shine with dignity to highlight the signs of love in hopeless situations.

For us, born and reared in the womb of African culture, religion and politics match perfectly. Our religiosity has no meaning if it is not translated in deeds. Religion and politics in Southern Africa are two sides of the same coin. Since we discovered the power of love in Jesus Christ, we ceased to accept to be dominated by those who seek power to destroy us. We stand for the truth and we know that God is on our 
side. "If God is for us, who can be against us? Certainly not God, who did not even keep back His own Son, but offered Him for us all" (Rom $8: 31$ ). By this very reason, He will give us what we need. The whole world is focusing its attention on Southern Africa. Namibia is about to become independent. The last colony in Africa will be free. Next year the people of Namibia will begin a new life. The first chapter of people's history book will start to be written. If Namibians succeed, Blacks in South Africa will rejoice; if it fails the shame will be shared by all of us.

Let us all come together and support the people of Namibia, pray and work for its success. Our prayer and work should be done intelligently with full knowledge of key historic facts. It is in South Africa that we find the most exciting interplay between Religion and Politics.

\section{SOME HISTORIC FACTS}

The land known today as Namibia was first visited by Europeans. In the 15th century, merchants had established a flourishing trade with the natives. In the scramble for Africa, in 1884185 South West Africa became a German colony. White settlement started soon afterwards. Wars were waged against indigenous people. The Herero and the Nama suffered most. Brutal extermination took about 80,000 lives. In the course of the first world war, when Allies in Europe were fighting the Germans, South African armies invaded South West Africa in May 1915 and occupied it. At the end of the war, the League of Nations decided that the former German colonies should not be distributed as spoils of war. They should instead form a "Sacred Trust of Civilisation". A Permanent Mandates Commission of the League was entrusted with the responsibility to supervise the former German colonies.

The mandatory power given to South Africa was "to promote to the outmost the moral well-being and social progress of the inhabitants of the Territory". The mandate in principle ended with the second world war in 1945. As it is always the case with Europeans in Africa, planning well in advance, the South African Government started incorporating South West Africa in its territory in 1933. When the United Nations was formed, South Africa found it convenient to say that the mandate had expired: The United Nations, unable to deal with South Africa, established a Special Committee on South West Africa. 
Years went by and no action was taken. Every effort made was frustrated by South Africa. In 1960, Ethiopia and Liberia, the only African Member States of the defunct League of Nations, asked the International Court of Justice to declare that the system of apartheid, promoted by the Afrikaner National Party, which won the 1948 election in South Africa, was inconsistent with South Africa's obligations in terms of the mandate. Six years afterwards, in October 1966, the UN General Assembly terminated South Africa's mandate to administer South West Africa. Two years later, in June 1968, the General Assembly of the United Nations adopted a resolution sponsored by African and Asian members to rename the territory "Namibia".

Aware of the strong position taken by Africans and Asians at the United Nations, South Africa sped up the process to complete the incorporation of Namibia. The territory was reduced to the status of a province. The major revenues of the territory started to be paid directly to the Republic Central Government. The police and military forces were integrated with those of South Africa. In the next two years, steps to create Bantustans were reinforced first in Okavango and then in East Caprivi. Kavango was proclaimed a self-governing territory in May 9, 1973. In total Namibia was to have ten Bantustans.

\section{AFRICAN OPPOSITION CAME PRIMARILY FROM THE CHURCH}

It is said that "by the time present borders of Namibia were defined by the colonial masters, the country has already been subjected to missionary activity for over half a century". The mind of the first missionaries was linked to a colonial racist mentality. As time went by the mind of Church leaders, renewed by the power of the Gospel, stressed the dignity of all God's children. To him who was a slave, the spirit of the Lord loudly said: "you are no longer a slave but a son". And since you are a son, "God will give you all that he has for his sons". (Gal. 4:7) The Gospel was preached and lived. Words and deeds, supported themselves wonderfully.

Between 1914 and 1945, the Church became a powerful agent of change. Europeans were amazed to see Africans take up leadership positions in the Church. Among Europeans, there were those who, 
influenced by anti-communist sentiments during the cold war, saw communism in any African who stood for the liberation struggle.

In 1947, the Evangelical Lutheran Church in Namibia became independent from its mother church, the Rheinish Mission. Two years afterwards, the Evangelical Lutheran Ovambokavango Church obtained its independence from the Finnish mother church.

Politicians started agitating in 1957 with the creation of the Ovambo People's Congress (O.P.C.). In 1960, the O.P.C. became the South West Africa People's Organisation. It was formed to unite Namibians to work together peacefully to end South West Africa colonial rule. It is worth noting that 1960 was also the year Ethiopia and Liberia filed a case at the International Court of Justice against South Africa.

In 1963, in order to build up a strong united base in the country, Church leaders of two Lutheran Churches started training their Pastors together to build the awareness of "One Namibia, One Nation".

Being prophetically inspired, in May 1964, the same leaders denounced the illegitimate and brutal ways South Africans were handling Namibians. In 1967, the two Lutheran Churches sent a memorandum to the South African Government, protested mass detention, population removals, rent rises, denial of freedom of movement and the torture of detainees. As it is widely and worldly known, the Lutheran Church in Namibia draws its membership from Whites and Blacks.

The Namibia situation has proved that in times of hardship, the fellowship of those who call themselves Christians tend to develop along race and class lines. Following the Vatican II Council, Germans living in Namibia, both Catholics and Evangelical Lutherans established close relationships among themselves on the base that "They were looking for a spiritual, non-political ecumenism. They accused the vocal Black Lutheran Church members in Namibia of mingling politics with faith and worship". For them, any opposition to the authorities as found in Rom 13:1,2 was against the mission of the church. This kind of teaching is beautifully handled by Dr Kameeta in his book Why, oh Lord.

The Anglican Church was also in crisis. Namibian clergy in the North contested the position of White Anglican Clergy. The first Whites to see the light were Anglican bishops, Colin Winter and Richard Wood. They sided with oppressed Namibians and consequently were expelled. 
Namibia has taught us that when Africans are provoked and become angry, they show their dissatisfaction either in prayer and verbal protest, or in strikes and violent actions.

SWAPO's early non-violent campaigns for liberation were met with violent repression from the occupying South African forces. This forced the movement to opt for the armed struggle which started in 1966. There are struggles that can only be won when the international community gives its support.

\section{INTERNATIONAL SOLIDARITY}

Structured international solidarity with the Namibian people started in 1971. The international Court of Justice found that the continued presence of South Africa was illegal and constituted threat to peace. In June 1971, the Court of Justice unequivocally declared that "South Africa is under the obligation to withdraw its administration from Namibia immediately, and thus put an end to its occupation of the territory". As it was expected, South Africa ignored the Court's opinion. Church leaders of two Lutheran Churches once again did not keep quiet. They denounced the policy of apartheid. They sent an open letter to Prime Minister Vorster asking him to read the Declaration of Human Rights and look at the situation of Black people in Namibia. They said "we believe that it is important... that the use of voting rights should also be allowed to the non-white population".

On February 4, 1972, the Security Council meeting in Addis Ababa requested Dr Kurt Waldheim "to initiate contacts with all parties concerned. .. so as to enable the people to exercise their right to selfdetermination and independence". The visit was made without visible progress. At a later stage, on October 3, Dr Escher (Swiss Ambassador to Austria) was sent to Namibia and South Africa. His report confirmed that Africans supported the establishment of a United, Independent State.

Throughout the 70's, political discussions in Namibia were conducted in church circles and youth associations. As a matter of fact, church membership and political involvement became complementary. The church started to be recognised by the South African regime as a force to reckon with. 
In 1974, Anglican, Roman Catholic and Namibian Lutheran Churches started a Christian Centre. Services offered include: legal aid, support for the dependents of political prisoners, welfare and educational assistance and medical help. Due to ecumenical cooperation of Anglican and Lutheran bishops, churches continued to denounce atrocities.

In 1975, one year after the creation of the Christian Centre, Angola and Mozambique became independent. In May of that year, South Africa was supposed to announce to the United Nations Security Council its withdrawal from Namibia. Aware of the consequences occuring from the April 25 coup in Portugal and the independence of Angola, a new strategy was announced. It included a national programme of oppression. Units of the South African Defense Forces were stationed along the border with Angola and Zambia, from the Atlantic sea to the Caprivi strip. South Africa also mobilised people in the North to fight their own brothers. In Namibia and in Angola, the aim was to destabilise the whole region.

In 1976 Kavango and Caprivi were already known as security areas in addition to Ovambo. Along with military plans there were also political initiatives. The Turnhalle Conference met between September 1975 and March 1977 to discuss the Territory's constitutional future. In the same year 1977, the contact group Britain, Canada, France, Germany and USA was formed.

According to the South African plans, in December 1978 Namibia should have become independent. In preparation for it, some departments previously controlled from Pretoria were placed in Windhoek.

In February 1978, there were proximity talks in New York for three days. Pik Botha was present, but did not stay until the end. He said that the tabled proposal leading the country towards independence was utterly unacceptable. "Under no circumstance could SWAPO rule Namibia." Fortunately, the family of nations seemed determined to go ahead. In April 1978, the United Nations Security Council passed resolution 435. Foreign Minister Botha objected to the seize of the proposed military component of 7,500 to be called UN Transitional Assistance Group (UNTAG). The resolution itself has loopholes. Worse for Namibians is the future of Walvis Bay, which was excluded from the proposals. In spite of this loophole beligerant South Africa, instead of seeking ways to end the war, intensified it. In May 1978, 
Kassinga in Angola was bombed, 600 Namibians were killed, many of them were women and children.

In the same year, Church leaders in Namibia, committed to peaceful settlements of conflicts, carried out more responsively their prophetic task by forming the Namibia Council of Churches, (CCN) which comprised Anglican, Evangelical Lutheran, Roman Catholic, Methodist and United Congregational Churches. Along these 11 years, the Council has taken "upon itself the role of denouncing the abuse of political power and calling on world opinion to condemn the illegal South African occupation and its established control of an interim government". Church leaders, through the Council had visited Namibians in exile and went to SWAPO refugee camps in Angola and Zambia.

\section{NEW FUEL TO THE FIRE}

New fuel was added to the fire when Zimbabwe became independent 1980. In January 1981, delegations from SWAPO and South Africa met for the first time in Geneva. $\mathrm{CCN}$ was present. The meeting collapsed partly due to changed American Administration. Ronald Reagan was in the White House in that year. This was the time William Clack and Chester Crocker visited South Africa and announced the so-called "Constructive Engagement Policy".

The period which goes from 1981 to 1988 was politically and militarily intensive. The South African regime, assisted by the American Administration tried all means to frustrate the people of Namibia, Angola, Mozambique, Lesotho, Botswana, Zambia and Zimbabwe. Mozambique and Angola were the worse hit.

The ascension to power of the Reagan Administration in 1981 legitimised direct South African attacks and presence in Southern Angola. In July 1985, the U.S. Congress repealed the Clark amendment which had prohibited U.S. aid to the Angolan "rebels", and UNITA started receiving substantial financial and military assistance.

Since 1975, more than 100,000 Angolans have died as a result of the war. More than 40,000 persons, mostly peasant women and children, have had limbs blown off by land mines planted in roads and fields. More than 690,000 Angolans are displaced and thousands more have 
been forced to flee to neighbouring states.

In Mozambique the South African regime started destabilising the country soon after independence by imposing economic sanctions. The serious economic downward trend began in 1981 following the independence of Zimbabwe. RENAMO launched a campaign to weaken the fabric of the Mozambican society, destroy villages, rural shops, schools and health posts. It is known that during the five years 1980-1985, about 500,000 lives were lost. Attacks by RENAMO on innocent civilians travelling by car, rail traffic, state farms, cooperative warehouses, have crippled agricultural production and rural commerce. Current estimates put the number of people in need of emergency food aid at 6.5 million of which 1.2 million people live in refugee camps. Since RENAMO started its attacks on civilians, more than one million Mozambicans have been displaced and one million Mozambicans have taken refuge in neighbouring countries.

\section{CONTRIBUTING TO CHANGE}

What has been witnessed in Southern Africa is a black holocaust. Fortunately we are beginning to see signs of hope. The policy of Perestroika is diffusing the tension built up over the years. There are other factors that have contributed to the changing situation in Southern Africa. Among them, the following are the most important:

1. Internationally, the world is longing for peace. People seems to feel that they are tired of solving differences by fighting;

2. The war in Namibia, where for every 15 citizens there was a soldier, started to be too costly for South Africa. On average South Africa was spending 1,000 USDollars per day in defense;

3. Sanctions particularly imposed in 1986 by USA based firms operating in South Africa started to bear fruit. Lack of fresh loans made the racist regime think that it could not hold fighting on forever;

4. The 1987 battle of Cuito Cuanavale in Angola, where for the first time the Angolan army showed that South Africa could no longer display their air superiority, contributed to seek ways to end the war;

5. The diffusion of the Cold War by Mr Gorbachev, change of Administration in Washington and the uncertainty about the behaviour of the successor to Reagan were of vital importance. 
As we said in the beginning, for us in Africa religion and politics go hand in glove. Among the.books of the Bible, which the African like best, is the Epistle of James, particularly chapter 1:22 where it is written "Do not deceive yourselves by just listening to this word; instead, put it into practice", in chapter 2:20 we read: "Faith without action is useless." The President of Kenya Daniel arap Moi, in a Harambee meeting, summed the symbiotic relationship between religion and politics when he said: "What is morally wrong cannot be politically right." 


\section{The Regional Prospects}

\section{Tor Sellström}

To talk about SADCC — the Southern African Development Coordination Conference - in a post-apartheid perspective must, of course, be highly speculative. We do not know how and when the democratic forces of South Africa will liberate that country, and thus the whole of the SADCC region, from apartheid, only that they will do so, sooner or later. The intervening period from today until Day L ("L" for liberation) will be crucial for the future of Southern Africa and SADCC. How will events unfold until liberation?

Several scenarios are possible here. One scenario, known to us all, is a continuation of the present situation, with a protracted struggle nationally, destabilization regionally and a mixture of support for and sanctions against the apartheid regime internationally.

Another scenario-quite possible I think - is that the apartheid regime under mounting pressure will go berserk and turn the present destabilization and low-scale warfare through bandit proxies into open war against the Frontline States.

Personally, I do, however, think, and hope, that the first scenario is more probable and that liberation in South Africa will be the outcome of mounting struggles internally and mounting pressures externally. I do also think that there will be, in the final event, some sort of negotiated settlement and that the transition from the presently prevailing nonpeace to peace in South and Southern Africa will take place without major destruction of the economies of the region.

For any speculation regarding Southern Africa — and SADCC — in a post-apartheid perspective, the circumstances leading up to the final demise of the political power of the white minority are, thus, decisive.

\section{THE TIME FACTOR}

Equally important is, of course, the time factor. I think most observers of South African events would agree that the longer the protracted struggle continues, the more radicalized the anti-apartheid forces 
become. This in turn determines the correlation of forces in South Africa on Day L of liberation, between labour and capital in a negotiated settlement, and thus the political course of the post-apartheid government would most probably have effects upon the neighbouring countries, and upon SADCC. For the SADCC countries, the time factor is also vital from other points of view. Continued destabilization and warfare through bandit proxies means a continuation of enormous losses of life and property. Already, since its formation in 1980, SADCC as an economic entity has lost around 30 billion US Dollars to South African aggression and destabilization.

Finally, SADCC was partly designed to de-link economically from South Africa - and has been quite successful in some areas, particularly within the transport and communications sector. The longer the antiapartheid struggle continues, the more likely it is that at least the more important of the SADCC economies will further disengage from and become less dependent upon South Africa, which could have both positive and negative effects for SADCC in a post-apartheid perspective. Positive, because the economic dominance of South Africa in the region is such that, with or without apartheid, SADCCs objective "to reduce economic dependence on South Africa" remains relevant. Negative because disengagement could also turn out to be a hindrance for the inclusion of a future liberated South Africa - then as an equal, rather than a hegemonic, partner - in a wider post-apartheid SADCC.

Let me - at least for the sake of argument — stick my neck out and speculate on a scenario for SADCC or Southern Africa in a postapartheid perspective. Before doing so, I think, however, that it is important to just in passing mention one scenario which defenders of apartheid explicitly or implicitly paint, namely that the fall of the present government in Pretoria would lead not only to so-called blackupon-black violence between ethnic groups in South Africa, but also to escalating contradictions and conflict between the Southern African states. We all know that this is utter rubbish.

\section{SECONDARY CONTRADICTIONS}

However, in the present era of post-colonial Nation-State building in Southern Africa, I do think that one should not disregard the risk for 
secondary contradictions once apartheid is gone. Such contradictions are a consequence of the uneven and unequal development under colonialism and of the divide-and-rule policies of apartheid, and there will of necessity be a quite bumpy road to travel in the beginning. I am sure, however, that these inherited contradictions - as in the case of Zimbabwe after the Smith regime-will be solved and not-as in Indochina after the defeat and withdrawal of US imperialism-degenerate into fratricidal conflicts. In Southern Africa, it seems to me that the post-colonial majority-ruled States have been successful in this respect, for example regarding real or imagined territorial disputes. Thus, to a great extent thanks to the inter-state cooperation through SADCC, the Kamuzu Banda dream of a "Greater Malawi ${ }^{u}$ - fomented and backed by Pretoria — has since 1980 been shelved, and yesterday's sabre-rattling towards Mozambique, Tanzania and Zambia has given way to the implementation of joint regional development projects.

\section{A SUGGESTED SCENARIO}

What is, then, "my scenario for SADCC in a post-apartheid perspective"? As all provisos have indicated, and as I stated in the beginning, all scenarios must be highly speculative. For the sake of argument, I will, however, assume that the process leading to the dismantling of apartheid and to Day L in South Africa will have the following course:

a) there will be a continued protracted anti-apartheid struggle in South Africa, with continued destabilization in the region and a mixture of support for and sanctions against the apartheid regime internationally;

b) before the apartheid regime reacts to the mounting pressure by going berserk and unleashing a full-scale war, preemptive international actions will be taken and bring about a negotiated settlement;

C) this will take place within "a not too distant future";

d) post-apartheid South Africa will have a strong, radical and organized labour movement;

e) the economic path chosen by the post-apartheid South African government will be that of a national/popular mixed economy, as has been indicated by the ANC; and 
f) liberated South Africa will, of course, terminate all support to bandit proxies like UNITA and RENAMO and instead join hands with the present members of SADCC and Namibia for peaceful economic development of the Southern African region.

When this fundamental change in Southern African history comes about, what will the likely economic prospects for South Africa and today's majority-ruled states of the region be? Will South Africa's economic power and the transition from non-peace to peace in the region lead to a generalized regional economic boost and boom? Will South Africa's considerable economic resources also benefit its neighbours and take the region out of its present underdeveloped status by international comparison? (In the mid-1980s, South Africa had a Gross Domestic Product of around 75 billion US Dollars, while the total joint GDP of the nine member states of SADCC corresponded to one-third of that figure, or approximately 25 billion US Dollars.) Will SADCC become a relatively strong regional economic organization in the world?

My own conclusion is that this will not be the case, at least in a short term post-apartheid perspective of, let us say, 10 to 15 years. It is, of course, true that Southern Africa is endowed with extraordinary natural resources, that the potential for strong economic growth is there and that the bringing to an end of apartheid wars will make it possible to turn swords into ploughshares. But it is - firstly-equally true that Southern Africa is far from being that economic powerhouse some observers claim it to be, and - secondly - it is important not to forget that the incoming South African post-apartheid government will have to attend to almost inconceivable popular economic demands which - particularly in our scenario of a strong, radical and organized labour movement-not only will commit all internal resources, but most probably will require additional external financing.

With regard to the economic strength of Southern Africa, including South Africa, it is commonplace to exaggerate. This is done by defenders of apartheid, who narrow-mindedly take the white wealth of South Africa for granted and transpose it to the majority-ruled states of the region "before Independence", i.e. before the Africans "messed it up". But it is also done by activists in the anti-apartheid struggle, who seem to think that the redistribution of white wealth will satisfy the needs of the exploited after Independence, i.e. when Africans are in political command. 


\section{ANOTHER THIRD WORLD REGION}

The fact of the matter is, however, that Southern Africa-including South Africa and Namibia - by international standards is just another Third World region. Thus, in spite of all its mineral wealth and other resources, the region as a whole, with a combined GDP of around 100 billion US Dollars, would be about half or even closer to one-third of the GDP of Brazil and the per capita income level of Southern Africa would fall into a range with, for example, Ecuador, Jamaica and Turkey.

The crux of the matter is, of course, that in Southern Africa the majority of income arising accrues to, or is controlled by, the minority white population in South Africa of some 5 million out of the region's 100 million people. Thus, 5 per cent of the region's population receive or control - conservatively speaking - at least half of the combined income of the entire region.

This anomalous, racially determined structure of islands of wealth in a sea of poverty and want is the core of apartheid and will have to be radically transformed in a liberated South Africa, even though liberation comes through a negotiated settlement it seems obvious to me that this transformation - for which the people of South Africa and the neighbouring countries are presently fighting and dying-will have immediate and far-reaching effects on South Africa's hitherto privileged economic position under apartheid.

Firstly, the mere scrapping of apartheid legislation, combined with labour demands of higher salaries and humane conditions of work, will most probably bring returns of invested capital in the South African mining industry and auxiliary manufacture on a par with-or even below-world average, which is the same as saying that the present comparative advantage on an international scale will be lost.

Secondly, the incoming new government in post-apartheid South Africa will, as was said before, have to attend to almost inconceivable popular economic demands hitherto only stepmotherly budgeted for, if at all, such as education for all citizens, health for all, land reform and distribution, administrative reforms, housing, expansion of the public service, etc. 


\section{UNCHECKED UNEVEN DEVELOPMENT AS A DANGER}

In short, as in Zimbabwe - but on a much larger scale - the independent government must budget for the needs of the entire population and not only for the white minority plus a handful of co-opted African members of a second-class middle-class.

In my scenario, a democratic South Africa would, consequently, have more than enough domestic problems to solve. For the region as a whole, liberation in South Africa-with the assumed termination of bandit activities in the area-would mean peace but also a normalized situation as an "underdeveloped region" in the economic South, having to deal with the economic realities in a world divided by yet another structural injustice, namely the fact that a few economies in the North - in relations similar to those prevailing in South Africa today - capture an undue share of our world's income.

Against this background, it is hoped that post-apartheid South Africa will enter into SADCC and that the countries of Southern Africa out of experience and co-ordinated political action will be able — through a wider SADCC — to forge a principled common front in favour of a New Economic World Order. Such a common front must be politically motivated. From an economic point of view, I fear that the uneven and unequal development between the Southern African countries will - if politically unchecked — be exacerbated in a post-apartheid perspective.

Thus, while it seems reasonably safe to assume that Botswana, Lesotho, Namibia and Swaziland will follow a so-called "pilote-fish course", being close to the dominant actor, helping him and getting spoils in return, it is likewise highly probable that Zimbabwe, having surpassed the ordeals of transition and possessing a competitive economic environment, will benefit from the scenario painted above by offering a base for investment in the region. With apartheid out of the scene, Malawi and Zambia-economies presently in deep crisis-will have to adjust not only to a post-apartheid perspective, but also to postBanda and post-Kaunda perspectives. For Mozambique, developments in and relations between South Africa and Zimbabwe will be vital, while Angola - a potential giant of Southern Africa - by geo-political necessity must look with equal attention towards North and South. Tanzania, finally, has never been part of the Southern African econ- 
omy, but has always been in the forefront of the political struggles for a non-racial Southern Africa. She will - most likely - maintain this historical commitment until the final demise of apartheid and the formulation of new policies of a wider SADCC. 



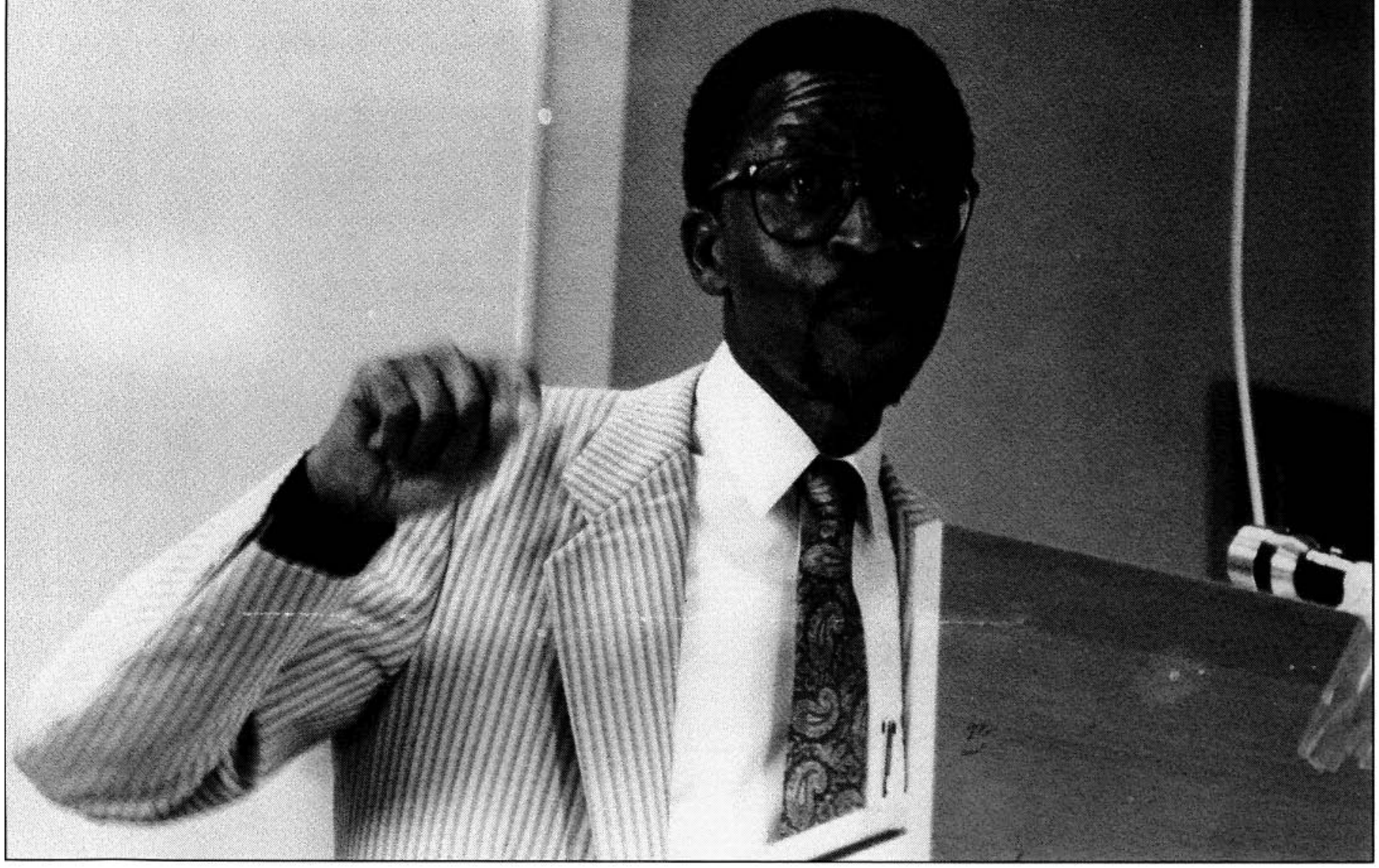

1.

Billy Modise, Chief Representative of the African National Congress S A, at the opening session calls for suggestive and supportive research on church and politics. Photo: Josephine Carlsson. 


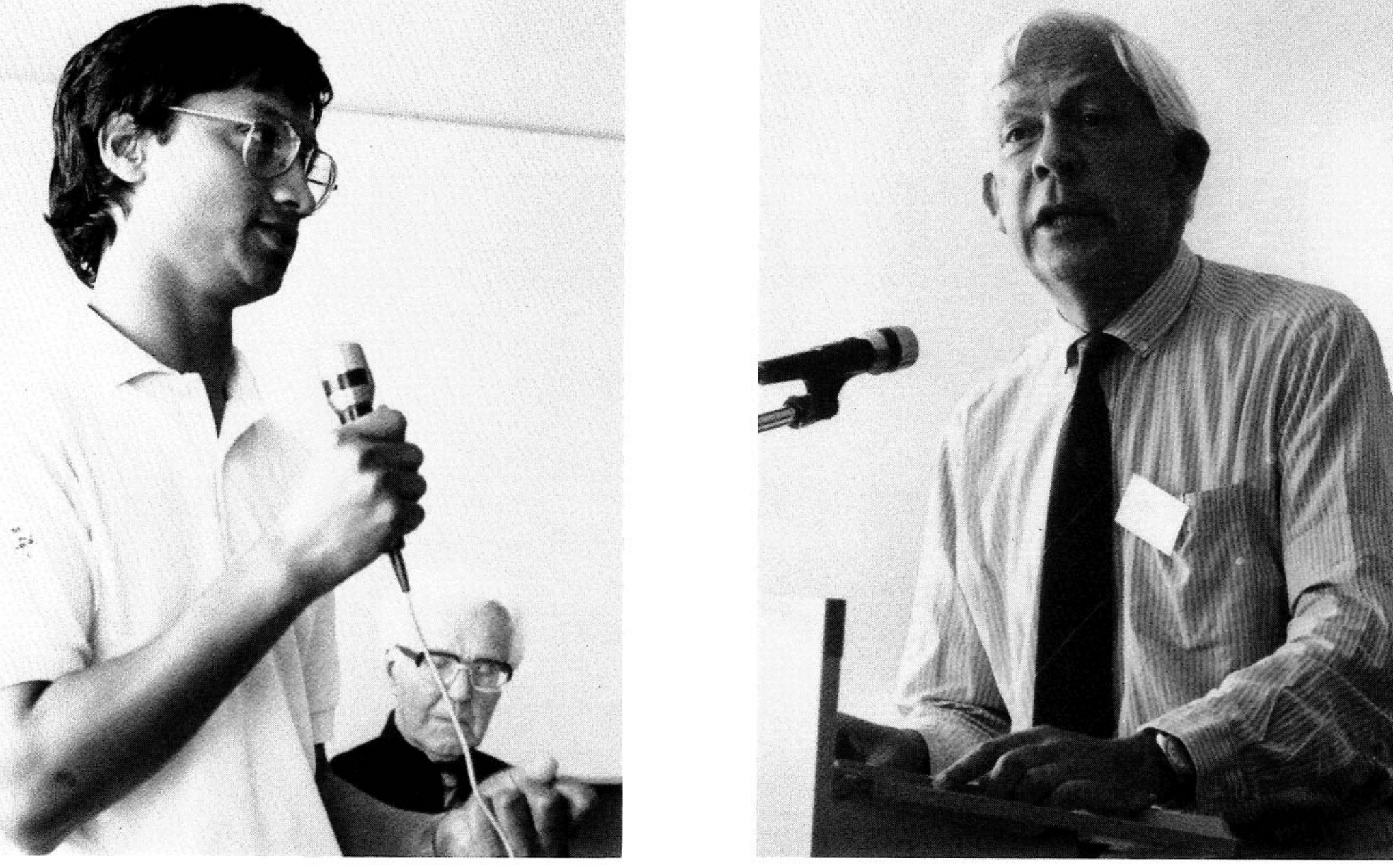

2.

The Rev. Alex Bhiman of the Institute of Contextual Theology, Johannesburg (left) and Professor Matthew Schoffeleers of Free University, Amsterdam (right) debate healing and politics. Photo: Swen Sundin and 


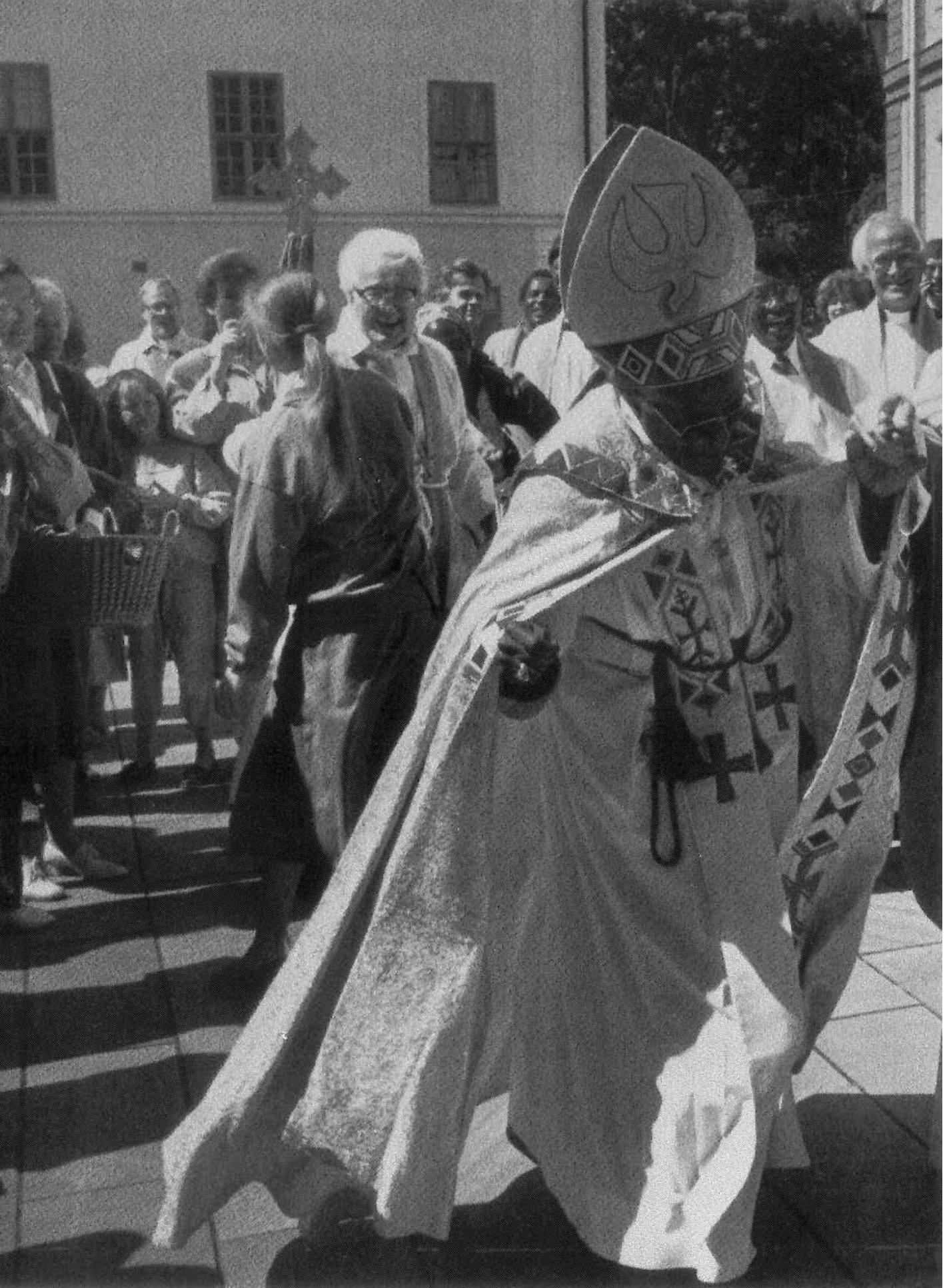

4.

Archbishop Destnond Tutu invites his host, Archbishop Bertil Werkstrom to dance after Eucharist in the Uppsala Cathedral on the final day of the seminar, June 18, 1989. Photo: Jim Peter Elfström. 


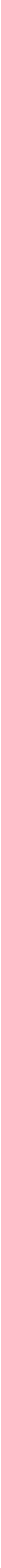




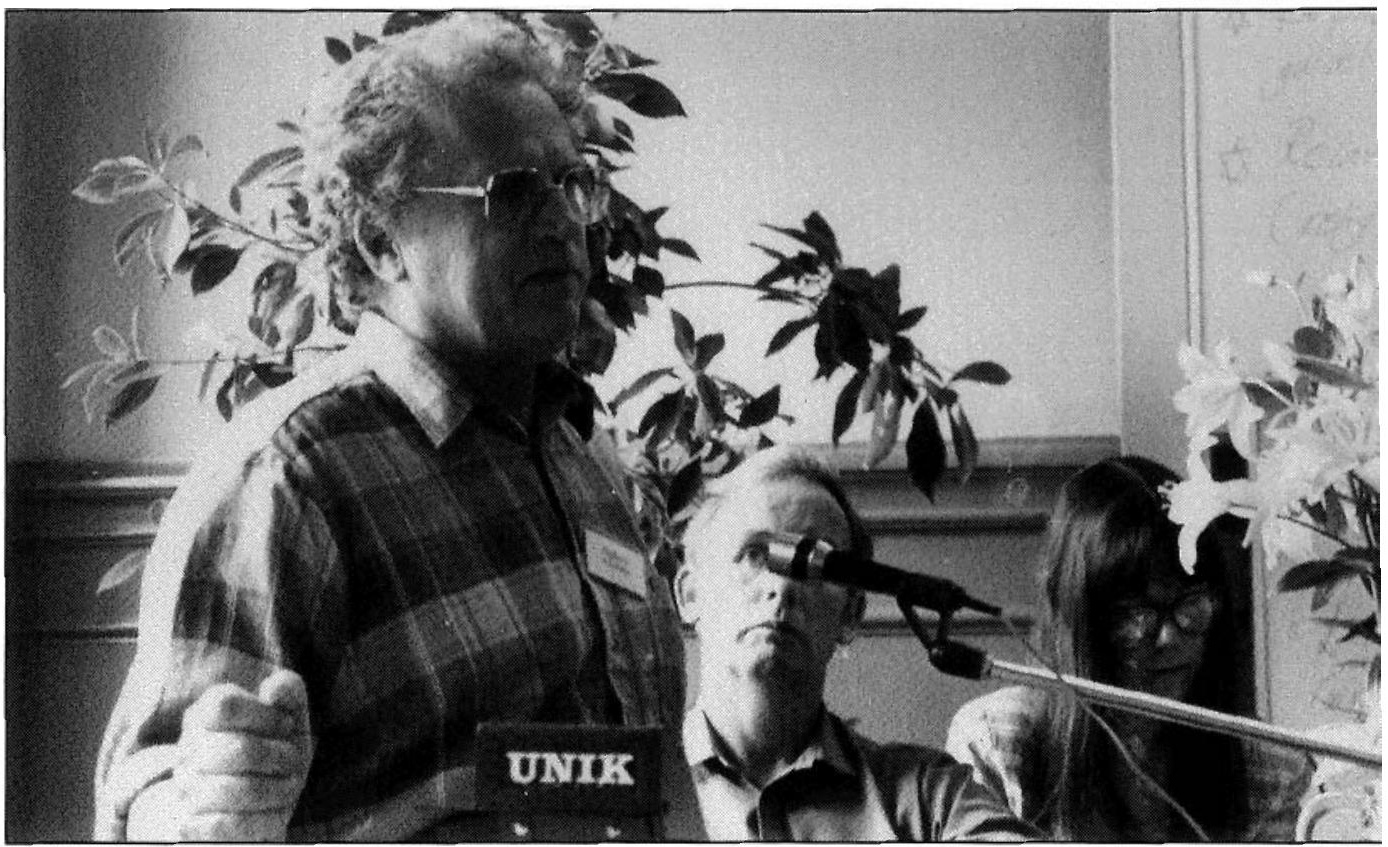

$5 b$.

Sigbert Axelson chairs the session on the religious rights movements in Southern Africa. Photo: Josephine Carlsson.

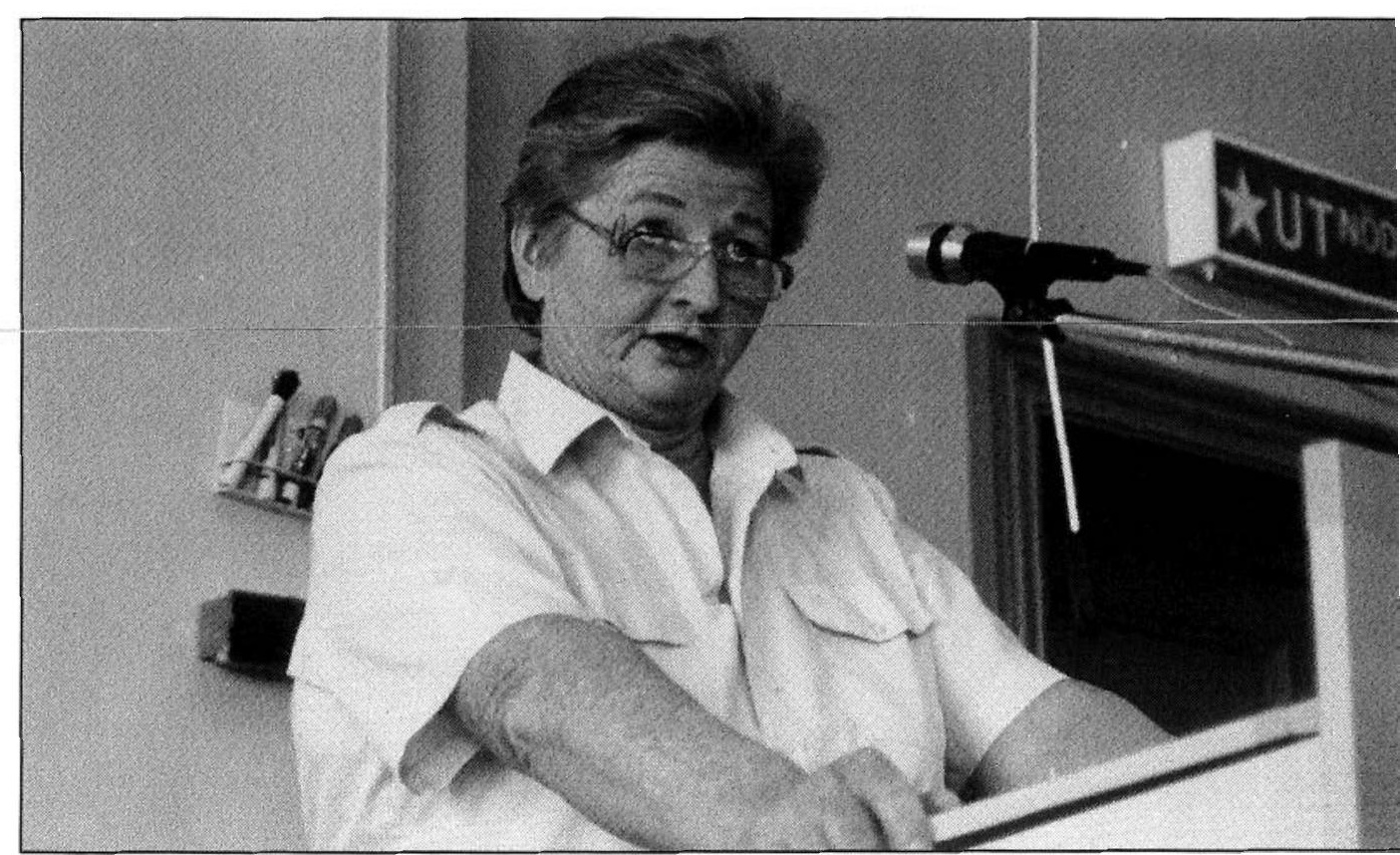

5a.

Sheena Duncan of Black Sash, Johannesburg, critically reviews theological claims in the South African apartheid constitution. Photo: Josephine Carlsson. 


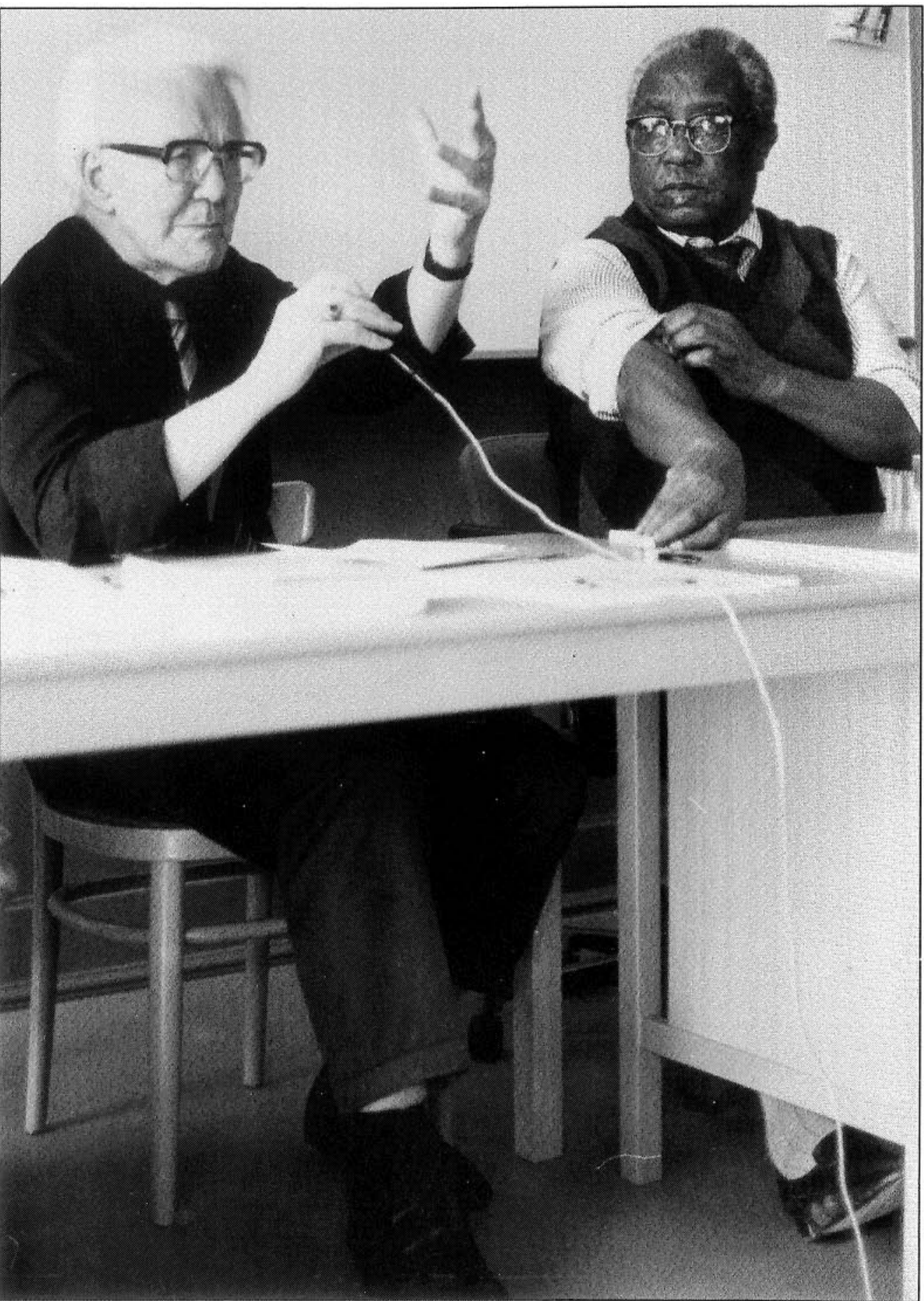

6.

The Old Men — Professor Bengt Sundkler of Uppsala University, and Gabriel Setiloane, Professor at the University of Capetown-discuss the political role of Independent Churches. Photo: Sven Sundin. 
Religion, Apartheid and

After 


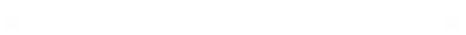

(2) 


\section{Towards Post-Apartheid South Africa}

Desmond Tutu

I work out of Cape Town. Cape Town is famous for quite a few things. It's got a nice mountain and so on... It is famous also for its graffiti artists.

Near the cathedral in Cape Town there is a wall. It has recently been covered with paintings. But before this it had written on it: Wrong rulers ruin Rand. And then someone wrote underneath that: Rather ruined Rand than Rubels. And somebody added a third line and said: Rather Rubels than rubble. But one of the other signs in Cape Town was one that said: God loves Boesak and Tutu. And somebody wrote in bottom of that: The gods must be mad!

Someone in South Africa, who is a theologian at the University of Witwatersrand, an Afrikaans professor, was a bit annoyed with the Archbishop of Cape Town, and he is not the only one. There are many others. He got annoyed, and he wrote and said: Actually there is nothing in Tutu, I mean, he is really a non-entity. Just imagine, where would Tutu be without apartheid? Where indeed? I would be back at home and sitting there and trying to be a nice bishop instead of going round the world thanking people and trying to urge people to intensify our struggle.

Friends, one of the extraordinary things about the victims of injustice and oppression back home, is their reliance. Sometimes, many of us feel a bit despondent. You know, the South African government seems to have very powerful friends.

You say to people, well one of the ways we could get rid of apartheid is, perhaps, disinvestment. And you talk to business-people and they say to me: Well, you know, in fact our investment in South Africa is minimal in relation to our total investments as a big multinational. And I say to them, if your investment in South Africa is so insignificant, why do you struggle so hard to keep it there?

There are huge amounts of time that we have to spend saying to 
people that we are opposed to violence. And do you think the people understand the English language? The English language is not my mother's language. My mother's tongue is another language. I do not speak in my mother's tongue. I speak in English, and I say I am opposed to violence. I am opposed to all forms of violence. Whether it is the violence of an unjust system such as apartheid, or if it is the violence of those who seek to overthrow it.

You would have thought that anyone who knows a little bit of English understands what I am saying. And the next thing you hear is: Actually the Archbishop of Cape Town supports violence. And you discover that we are facing a massive onslaught on our people.

I was looking at a poster that was put up by a group that is related to conscientious objectors. It was a cartoon that is divided in halves. On one side it showed a political prisoner, and they were saying there: Renounce violence and we will release you. You know what they say to Nelson Mandela: if you denounce violence, there will be no problem.

The second half of this cartoon shows a conscientious objector who says: But that is what I have done. I have reonounced violence, and they sentence me to a six year imprisonment.

We are a crazy country: South Africa. We play about with words. You know what they say: We got democracy. We got parliamentary democracy. Because there is a government party and there are opposition parties and then they will have an election. And people outside South Africa say: but give them a chance, they actually have elections.

How could South Africa even begin to claim to be democratic. When 73 per cent of the population is excluded? In the latest constitution, the 1984 model, 73 per cent of the population, the vast mjority of that country, is excluded. In that constitution we, the blacks, are mentioned in one sentence. And after that, so far as that constitution is concerned, we do not exist.

A new election is going to happen. This is 1989. You know that? In 1989 an election is going to be happening in South Africa. Eleven years from now is the end of the twentieth century. And 73 per cent of the population is not able to participate in that election!

That election is going to happen on September the 6th. You know September the 6th? Do you remember that date? Fifty years ago, September the 6th, 1939, the world declared war against Nazism. Fifty years ago the world was going to war to get rid of Nazism. Fifty years 
later an election is going to happen in a country that claims to be Christian. An election that is based on etnicity, i.e. an election that is based on precisely the same ground as Nazism. And the world sits by and does nothing.

The world says: no, no-be patient. Give them a chance! The world is aware, is it not? That we are sitting now under the fourth successive state of emergency. In which the authorities have taken to themselves the kind of power which most governments, which claim to be democratic would not want to have. Totalitarian governments, police states: look on in envy at the kind of power the South African authorities have!

And the world looks on and does nothing. The world says to the victims of injustice and oppression: Give them a chance, give mister F. W. a chance. And people say: The only thing that has changed is that we have had a P. W. and now we have a F. W.

South Africa claims to be a Christian country. Let me just tell you: I sometimes walk in the park of the hospital Grootes Schuur in Cape Town. And as I was walking one day somebody said: Oscar Mpeta was a patient here in this ward.

Oscar Mpeta was one of the presidents of the United Democratic Front. He was a trade unionist, over eighty years of age. He was a diabetic who had one leg amputated. He was sentenced to a mandatory five years imprisonment. He lied in bed. He could do very little for himself. And there sitting next to him were two armed wardens.

I went to them and asked can I greet him? The wardens, carrying out instructions, said no. And then I said: I am going to pray with him. They looked very uncomfortable. Then I went and I prayed with him.

Then I said, now I will ask for permission so I can say hello to him. And I sent in an application. They refused me permission! They refused me permission to pray with a man who is dying. In a country that claims to be Christian!?

But, you see friends, I have not come here to make you feel sorry for us. I want you to know that you have to make a choice as the world made a choice over Nazism.

I give you the opportunity of saying: Am I going to be on the side of injustice or the side of justice? Am I going to be on the side of humanity or on the side of a dehumanizing system? Am I gong to be on side of victims or on the side of the perpetuities of injustice and oppression? 
Because you see, I have not come here to say: I wonder if we are going to be free! As if that was a matter in doubt. I am saying to you: Join us. Join us in an accelerating struggle to bring about a new South Africa. Because we have a tremendous South Africa, a tremendous country.

Sometimes, perhaps, people are led to think that white people in South Africa is not nice people. There are nice people amongst them, as there are nice people amongst the blacks. There are bad people amongst them as there are bad people amongst the blacks. I just want to tell you about maybe one or two signs of hope.

I was chosen to be Secretary General of the South African Council of Churches, when they said: it is necessary to have a black person as General Secretary, because the majority of Christians, whose churches are members of the Council of Churches, are black. For seven years I was General Secretary. And then, when I was leaving to become bishop of Johannesburg, they appointed, without lifting an eyelid, a white man to succeed me, and nobody thought it was funny.

But, you know, the white man whom they appointed to succeed me was an Afrikaaner. He was a minister of the white Dutch Reformed Church. His father was a founding member of a secret society, one of the most powerful Afrikaaner societies in South Africa. He was, himself, one time a member of Broederbond, this secret society.

Incredible, that it could be possible in that crazy country, for an organisation that said, we must prove to ourselves that we really care about the struggle, to appoint this kind of a white man that you all know, Beyers Naudé. And I said to Beyers: You are one of the greatest signs of hope in South Africa! Because, if anyone with your background, with all that has happened to you, can move from where you have been to where you are today, how can you give up on anybody else?

Another sign of hope: We went to a funeral of 17 victims who had been shot and killed by the police. I was sitting at the platform with Allan Boesak. There were 50,000 people at this incredible funeral. One of the most intensely emotional occasions, where people were feeling very angry over what the government had done. I said to Allan, just look at these two young ladies! They were sitting together and they were hugging each other. They could not hear me. But when I was whispering to Allan, it was as if they heard me. They turned even closer to each other. 
Well, there is nothing particular with two young women hugging each other at a funeral. Except that one of these was black and one was white. It was such a wonderful symbol, such a wonderful sign, such a wonderful sacrament. That at this kind of a funeral, when you would have thought that black people would say, to hell with white people, there you would see these two girls sitting together.

And think of another funeral of people who had been killed very mysteriously. Allan Boesak and Beyers Naudé attended that funeral. And again, the vast majority of the people would have been black people. At the end of the funeral, they carried Allan Boesak shoulder high. But you know, they carried Beyers Naudé also, shoulder high.

Do not think I am sobbing when I talk about funerals! They are important. And the Government knows that they are important. That is why they apply restrictions.

Incredible, when you look at it you say that it ought not to have happened. People ought to be saying, we are sick and tired of white people. They have oppressed us. They have killed us. No, no, our people say, we recognise a person to be a person, because they are persons. We do not recognise that the colour of the skins says anything particularly important about a person.

And then the last example: Only recently, David Webster was gunned down by a death squad. At his funeral, the vast majority of those who attended were blacks. And many of those were young radical blacks. Now, in an incredible kind of way the government actually makes people come to realize that our destiny is bound up with one another. There was a young boy at the age of eighteen, who made up his decision. He is a white boy. He says, I refuse to serve in the South African Defence Force, because the South African Defence Force is defending something that is indefensible - apartheid.

In South Africa it is not easy to gain the status of a conscientious objector. This young boy, eighteen years of age, Charles Bester, has been sentenced to six years imprisonment. But there is a kind of hope when this young person can believe so strongly in justice and humanity, that he is willing to pay such a heavy price.

In my own diocese in Cape Town I have a young doctor. He had been in the army before, but decided that he did not want to continue. He said, my hands are hands that are maid for healing. I can not use them for killing. His name was Ivan Toms. 
I remember going to the clinic in Crossroads where he was working after he had been arrested. He was sentenced to 18 months for refusing to continue to take what they call camps. I went to the clinic. And there were these ladies. Black old ladies who had been his patients. We were talking with them. And then they started praying. With tears rolling down their wrinkled faces they were saying: Please God, help this child. Protect him. Protect him.

Here was someone who without making political speeches was working as an instrument of healing and true reconciliation. And the people recognised it. That is one of the wonderful signs of hope in a crazy land.

We try to say to our white brothers and sisters in South Africa, you know, that we Africans have got something which is difficult to translate into other languages. We have got a thing which we call ubunto, which means humanity.

Ubunto really means that $\mathrm{I}$ am because you are. We belong in a family. We belong together. Our humanity is bound up with one another. We say in our languages, a person is a person through other persons. A solitary human being is a contradiction in terms. I learn how to become a human being through association with other human beings. I would not be able to know how to talk without having learnt it from other human beings. I would know how to be human except I learnt it through association with other human beings.

Our people say ubunto. Ubunto is something you say when someone has wronged you. What you long for is not revenge. What you long for is a healing of relationships.

We say to our people in South Africa: you want to see how it operates? Look at Zimbabwe. You were told that Mr Mugabe is the devil incarnated. And then, at the day of his election victory $\mathrm{Mr}$ Mugabe spoke for himself. White people, in Rhodesia as it then was, were sought out of their skins. There is a man, talking not about revenge, but about reconciliation, rehabilitation, reconstruction.

When you go to Harare, of course you see problems. Who said there would be no problems in a new country, when there are problems in the old country. But there are not the kind of problems that people thought would have happened, that white people would find themselves digging their own graves.

White people did run away from Zimbabwe and ran to South Africa. Now, they are running back to Zimbabwe. Because they have seen that 
it is possible for people coming from different races and different background to cohere.

And so I come to tell you here, my friends, that we have no doubt at all that we are going to be free. We know that we are going to be free. Our freedom is not a gift that we have to ask for from white people. No, our freedom is inalienable. Our freedom comes from God.

All we are saying: can you help us? So that when that victory comes, it comes with the least possible expenditure in human lives, in lost property. We are saying: we are going to be free. We would like to be able to invite you. Come on, to our celebrations of our freedom. We would like that to happen soon. You have in the West a critical role to play. You are wonderful people here in Sweden. We would hope that you could persuade others of the Western family of nations that their best interests are going to be served by ensuring that apartheid is destroyed before it destroy us. We do not go around feeling sorry for ourselves. Things are rough, yes, but we do not doubt.

And we say to our white brothers and sisters in South Africa: do come, and join the winning side! Because we want a freedom that will include you. For you are as unfree as we are. You spend so much time trying to protect your freedom that you have little time left to enjoy it. What a wonderful country ours will be, when all of us, black and white, will walk with our heads held high, What a wonderful country it will be which instead of sowing destruction, as it does now in Southern Africa, will become a country that will launch the countries in Southern Africa into the 21st century. What a tremendous country it will be when Nelson can sit with F. W. de Klerk in the same government. It is not a dream, it is just telling you what is going to happen. And you will have, depending on what you do, honoured seats as we celebrate our freedom. 


\section{The Role of Islam in Southern Africa}

Ephraim Mandivenga

Although the northern boundary of Southern Africa is the Zambezi River, any consideration of the Islamic scene in this region would be incomplete without reference to Malawi, for a major wave of Islamic penetration into this part of the world emanated from that country. To be precise, by far the largest single group of Muslims in Zimbabwe are Malawians who migrated into this country since the turn of the century. Moreover, a significant number of Muslims in South Africa are Malawians.

How had Islam been implanted in Malawi? Unlike Islam in West Africa - which had spread from north to south through the transSaharan caravan trade - Islam in East Africa had expanded from East to West: from the Indian Ocean and its littoral to the African interior, including such countries as Kenya, Tanzania, Uganda, Malawi, and Mozambique. This Islamic expansion may be ascribed to the centuriesold peaceful Indian Ocean trade. Trade is usually a key factor in Islamic expansion, for Muslim traders are often missionaries, and Muslim missionaries are not infrequently merchants.

\section{THE COMING OF ISLAM TO SOUTHERN AFRICA}

Islam was brought to Malawi particularly in three main ways. The first was the attempt, on the part of four Swahili Arabs, identified as Jumbes, to establish small sultanates on the Lake Nyasa coast. The Jumbes were local rulers who, as walis (representatives) of the Sultan of Zanzibar, governed local communities of Marimba on the western shore of Lake Nyasa for more than fifty years (1840-1894).

The Jumbes, having established amicable relations with the principal local tribes - the Chewa, the Ngoni, the Yao and the Tonga-propagated Islam in a variety of ways: they made Islam the court religion; 
they insisted that their children be taught Arabic and that the sons undergo circumcision as an Islamic rite (locally called jando); they themselves practised Islam and promoted Islamic culture in their areas; they refused to allow Christian missionaries to evangelize their people, contending that their subjects were not heathens: they had their own religion - Islam.

By the end of their fifty-year reign the Jumbes had introduced many facets of Islamic culture and had "left Nkhota Kota and the surrounding districts a heritage of Mohammedanism which obstinately resists all the advances of Christian missionaries".' Currently Nkhota Kota town remains one of the strongest centres of Islam in Malawi; it enjoys a Muslim population of between 20,000 and 30,000.

The second major way in which Islam was brought to Malawi was the conversion of the Yao tribe. According to Alpers, "the most important source of Islam in Nyasaland ... stems from the conversion of the Yao tribe". ${ }^{2}$ The Yao, who had migrated en masse from Northern Mozambique (between 1859 and 1861) where they had enjoyed trade relations with Eastern Coast Muslims for centuries, began to embrace Islam when several of their chiefs had been converted. The chiefs, Makanjira III, Mataka, Jalasi and Mponda, adopted Islam because they wanted to consolidate links with their trading partners (Arabs and Swahili), to be literate in Arabic and Swahili, to modernize and to strengthen their power by raising their own status. The Yao remain the largest single group of Muslims in Malawi today.

The third way Islam came to Malawi was the European colonisation of East Africa and the reaction of the Swahili and the Yao to what they regarded as an insidious threat to their mutually lucrative trade in ivory and slaves. ${ }^{3}$ Supported by the Yao, the Swahili organized anti-European resistance along the Great Lakes. Moreover, the Yao rallied round Islam and required all their sons to undergo circumcision as an Islamic rite. Since Islam had become a centrepetal force among the Yao, many more of them including chiefs, embraced Islam. One reason why the Yao rallied round Islam was to demonstrate their opposition to the role of Christian missionaries, which they construed as an aid to colonialism.

The mission of the Jumbes, the conversion of the Yao tribe and the response of the Yao and Swahili to European colonization of East Africa - all contributed to the implantation of Islam in Malawi which 
today has a Muslim population of $686,000.4$

Islam was brought to Zimbabwe for the most part from the north by Malawians who came to work and to settle in this country from 1900 onwards. Most of these Muslim Malawians are Yao, Lomwe or Chewa from Nkhota Kota, Machinga, Mangochi and Cholo districts where Islam is still very strong today. These districts are adjacent to the Lake Malawi littoral where most of the trade between Malawian chiefs and Muslim Arabs flourished. The Malawian Muslims in Zimbabwe number at least 52,000 in a Muslim population of 61,000. The second largest single group of Muslims consists of Indians who brought Islam from the Orient from 1900 onwards. They came to take advantage of the economic opportunities created by the British colonialists. They number 6,000 in an Indian population of 12,000.

As for South Africa, two major migratory waves brought Islam to that country. The first was that of so-called Malays: these were slaves or servants of the Dutch who came in the 17th century. The term "Malay" is somewhat a misnomer because the majority of these Muslims - now designated Cape Muslims - were political exiles or refugees from the Indonesian Archipelago. Although some were indeed Malays, others were from Borneo, Java, Celebes and yet others came from as far as Western India and Madagascar. Numbering at least 163,000 these coloured Muslims constitute the largest single group in South Africa today.

The second wave was that of Indians who came as indentured labourers to work in the sugar plantations in Natal. They were subsequently followed by their compatriots who, as "passenger" migrants, came of their own accord with capital to make a living in South Africa as entrepreneurs. While the first group settled in Natal, the second settled in the Transvaal for the most part. Indian Muslims today number 154,000 and they came in the last century, that is, about 200 years after the first arrival of Cape Muslims. Additionally there are 8,260 African Muslims, comprising mostly Malawians and Mozambicans. With an additional 2,180 Whites, the total Muslim population of South Africa is 338,000. 


\section{ISLAM, CHRISTIANITY AND COLONIALISM IN SOUTHERN AFRICA}

There is ample documentary evidence indicating that Muslims became politically active in Southern Africa from as early as the 16th century. Both the reports and the tragic fate of Dom Goncalo da Silveira, the Jesuit priest, who in 1560 tried to covert the Mutapa but was executed at his court, provide illustrating examples. ${ }^{5}$

There were subsequent critique of Muslims in the Mupata empire, which straddled what are now Zimbabwe and Mozambique. That Islam never completely left Mozambican soil since that time is corroborated by the fact that Mozambique today still enjoys a Muslim population of $1,685,000^{6}$

Unlike Islam, Christianity arrived in Central, Eastern and Southern Africa if not as part of colonialism, then at least in close association with it. There is considerable evidence to confirm the contention that Christianity reached Southern Africa simultaneously with colonialism. Father Silveira, as we saw earlier, came to the Mutapa Empire in advance of Portuguese colonisers; Father Fransisco Monclaro accompanied Barreto in a Portuguese expedition despatched ostensibly to avenge the murder of Silveira (but ultimately to colonize what is now Mozambique); LMS missionaries aided Cecil John Rhodes' mission to the Matabele by acting as translator and mediator. In the light of these realities, African nationalists, despite the adoption of Christianity by many Africans, came to view it as the religion of the powerful, the faith of the oppressors. Furthermore, although thousands of weak and poor Africans have become Christian since the dawning of the colonical era, Christianity, in their view, remains the religion of the affluent and the strong, particularly in apartheid-ruled South Africa.

However we ought to concede that not all Christian missionaries contributed to the colonial stigma associated with Christianity today: some vociferously opposed colonialism and the attendant oppression of the black majority; others even suffered not only incarceration, but deportation as well; Bishop Donald Lamont of Zimbabwe and Father Trevor Huddleston of South Africa were deported; Garfield Todd of Zimbabwe and Archbishop Desmond Tutu were harassed or detained or both.

Islam in South Africa came as the religion of the weak and the 
oppressed. We are referring here to the Cape Muslims who, as we saw earlier, came as servants, slaves, convicts or exiles along with their Dutch masters who were favourably disposed towards Christianity.

The response of the Muslims to the challenge of colonial Christianity led to a significant resurgence of Islam. For instance, to counter Christian missionary education, which they considered Western and therefore secular, Muslims required their offspring to shun Mission schools and acquire their education exclusively at Islamic institutions: Quran school, the Madrasa, the Mosque and the Muslim home. Christians, however, gained more converts, by offering treasured education with one hand, and their religion with the other. This two-pronged approach was effectively used with minor variations in most Britishcolonized states in Africa. Muslims contemplated more effective strategies: having discovered a significant connection between Christianity and colonialism, the Yao, as we saw earlier, used Islam as a centripetal force, as a shield against the impending colonization of their country by the British. They turned to Islam en masse not for spiritual reasons, but for strategic ones: they wanted to improve and to consolidate their lucrative relationships with the Arabs and the Swahili-potential allies in their struggle against British colonialism.

Conscious that their religion was merely tolerated in a pro-Christianity Rhodesia, some Islamic countries extended moral and material support to the African nationalists during the liberation war (1975-1979). Pakistan, Libya, Algeria, and Egypt are cases in point, and they have all established embassies in Harare since 1980.

\section{ISLAM IN SOUTH AFRICA}

Turning now to Islam in South Africa we ought to realize that it had a particularly trying start. A prominent writer on Islamic affairs in South Africa, Gerrie Lubbe, reports that in the Batavian Empire, of which the Cape was a part, the Islamic activities of residents were severely restricted.' This point is corroborated by A. Davids, who reports on Tuan Guru, an influential Cape Muslim, who in 1793 was released from imprisonment on Robben Island. On reaching the mainland he applied to the Cape State authorities for a site on which to build a mosque. When the application was declined, "Tuan Guru then led the 
Cape Muslims in open-air congregational prayers in the disused quarry just off Chiappini Street in the Malay quarters in defiance of the law". In fact, practising Islam in public or converting the local people was a crime deserving capital punishment. It was not until 1804, during the second British occupation of the Cape, that Islam could be freely practised for the first time in South Africa. ${ }^{8}$

Following this difficult beginning, the subsequent history of Islam in South Africa was characterised by three distinctive features. Gerrie Lubbe writes:

Islam in South Africa has for its entire history shared the position of the underdog with the rest of the oppressed, has known and offered ... resistance against injustice and oppression and is of a distinctly popular nature with the innate potential of mustering large-scale grass-roots support. 9

Having experienced a difficult beginning, Islam had to adapt itself to survive in a hostile environment. This being the case, its role in South Africa became fairly predictable: muslims would struggle initially to maintain their right to practise their faith without let or hindrance, and, ultimately, to remove any prevailing injustices and inequalities from South African society as a whole. Goolam Karim recently described the role of Muslims thus:

Muslims have made a significant contribution in the past and they have an important role to play in the future in the elimination of inequality, race discrimination, oppression and exploitation. ${ }^{10}$

Even after 1804, the conditions of Islam in South Africa were precarious. Two examples suffice:

In 1840, when a smallpox epidemic broke out in Cape Town, the authorities required all patients, regardless of religious affiliation, to be hospitalized. Aware that hospitalised Muslim patients would inevitably be denied halal food, and that those who succumbed to the disease would be denied Islamic burial rights, including the option not to be interred in coffins, the Muslim community refused to comply. ${ }^{11}$

In 1886 the State authorities in Cape Town decided, for sanitary considerations, to close down the main cemetery of the Muslim community. Although the decision was completely against the wishes of the 
Muslims, the authorities proceeded to close down the cemetery on January 15. A couple of days later, in defiance of the law, 3,000 Muslims buried a child on the site in question. ${ }^{12}$ Consequent upon this protest action of the Muslims, rioting broke out and law and order were disrupted for three days.

\section{ISLAM AND THE APARTHEID STATE}

In more recent times conditions have been qualified by the Apartheid policy of the Afrikaner State and its Dutch Reformed Church (DRC). In 1961 a DRC clergyman and a Muslim leader discussed the question of whether Jesus had suffered physical death on the cross. The debate took place publicly at the Greenpoint stadium. The DRC hierachy chose this occasion to distribute a pamphlet entitled "The Story of Hadji Abdullah" which contained not only slanderous remarks against Muhammad, but also unwarranted attacks on Islam, Outraged by the unprovoked attack on their faith, 20,000 Muslims gathered at Greenpoint on September 17, and unanimously passed a strongly-worded resolution denouncing the attack on Islam.

In 1985 hundreds of Muslims took to the streets of Cape Town to join Africans in protests against the Apartheid regime. The political consciousness of the Muslims had reached a new peak, and many eminent Muslims were detained. Nearly a year later, in 1986, the DRC hierachy warned Muslims against participation in revolutionary activities and denounced Islam as a false religion which threatened Christianity in South Africa and abroad.

In a bid to improve the deteriorating relations between themselves and the Muslims, the DRC leadership contemplated holding a meeting with the latter. However, when several Cape Town based Muslim organizations learned of the planned meeting, they issued a joint statement in which they distanced themselves from the proposed talks and declared that the DRC's problem with Islam was really the growing Muslim involvement in the anti-apartheid struggle.

While the two incidents we have just described are attributed to the work of the DRC, they reveal the attitude of the Apartheid State authorities to Muslims. In the first case the government was asked to proscribe the anti-Islam pamphlet, and in the second case the dismissal 
of Rev. Colyn (who had formulated the anti-Islam resolution) was demanded. The official response in both cases was silence. It became apparent to the Muslims that the DRC leadership and the State authorities were one and the same enemy. With the passage of time it became evident too that Islam was officially regarded as an undesirable movement; it was regarded as being rather like communism.

As recently as 1970, Muslims adopted an unequivocal stance against the apartheid system. A leading Muslim, Professor Fatima Meer, wrote as follows:

While Islam works for the dignity and the freedom of the human individual, apartheid works for the enslavement of man to the forces of prejudice and fear. It is in these fundamental respects that the two ideologies are in a state of conflict. ${ }^{14}$

So it would seem, the fundamental socio-moral principles of Islam and the basic political philosophy of apartheid are irreconcilable. Subsequently, in 1980, another eminent Muslim, Maulana Farid Esaq, commenting on the question of the Presidents' Council (an issue in the air then), declared:

It is clear from the Quran and numerous teachings of the Holy Prophet that no form of cooperation with any of the forces of oppression is permitted under any circumstances in Islam. We therefore cannot speak of working within the system to meet it. The norms of the powers that be are based on greed, selfishness and exploitation and there is no way that one can sit with these people and hope to be a participant in the struggle for social justice. ${ }^{15}$

The above passage is self-explanatory. In 1984, on March 23, the Muslim News editorially supported Muslim views on apartheid by citing the following Quranic verse:

Whoever recommends and helps a good cause becomes a partner therein; and whoever recommends and helps an evil cause shares in its burdens. ${ }^{16}$

In simple terms Muslims are submitting that it is noble to help a good cause; apartheid is not a good cause but an evil one; accordingly, anyone who helps apartheid is an accomplice of the atrocities and murders perpetrated by the Apartheid Regime. 


\section{THE SOCIO-RELIGIOUS APPEAL OF ISLAM IN APARTHEID. RULED SOUTH AFRICA}

As recently as 1985, Gerrie Lubbe reported that there are persistent rumours of the rapid growth of Islam within the Black community in South Africa. ${ }^{17}$ While we wait for the rumours to be confirmed, it would be intellectual self-enrichment to grapple with the reasons why Africans are turning to Islam. It has been discovered that some Africans are adopting Islam because in Allah they are rediscovering the original God of Africa; conversion to Islam is prompted by negative experiences with Christianity, such as being turned away from a segregated Church service, hearing derogatory remarks about African culture etc; Christianity is being seen as the faith of the oppressors who perpetrate apartheid in the name of God. ${ }^{18}$ Outlining the challenge Muslims pose to Christians, Lubbe writes:

If Muslims assert that the God of Islam is the God of Africa it is a clear hint at the unacceptable doctrine of the Trinity in Christianity. A valid question which then faces the Christian Church is how well have we succeeded in translating this and other key doctrines of our faith into audible and liveable terms in the context of Africa. ${ }^{19}$

Because Islam came to South Africa as the underdog, its progress was not impeded by the colonial stigma that has made Christianity somewhat repugnant in some quarters. The fact that the first Muezzin (caller-to-prayer) appointed by Muhammad himself was Bilal, the Abbysian slave (who was freed on becoming a Muslim), was and continues to be a profound source of inspiration, for Blacks can proudly say: "There is no more shame in this Blackness." ${ }^{20}$ Stressing that Islam has no discrimination based on colour, race or wealth, Muslims are challenging Christians to distance themselves from the Christian nationalism that has become the state or civil religion of the Apartheid rulers. Christian leaders should realize that Christianity, divested of the political connotations attached to it in the State constitution, is, like its sister religion Islam, the antithesis of apartheid.

Turning to Islam, we observe that it, too, must adapt itself sufficiently to the African context in order to be more pertinent and attractive to the African majority.

In the words of Lubbe: 
Islam will be challenged to adopt a more African outlook, not in terms of worship or structure, but in terms of involvement in and sympathy with the struggle for liberation. The challenge before South African Muslims is really: "Relinquish your so-called cultural identity and become an African."21

What the above citation implies is that Muslims should cease identifying themselves as Indian Muslims or as Coloured Muslims: they should forego their ethnic identity and pursue an outward-looking policy whose hallmark is a willingness to reach out to the African majority and to Europeans. They should not confine Islam to themselves since this tends to give the impression that this faith is exclusively for certain ethnic groups.

In conclusion, Muslims and Christians should avoid being inordinately influenced by narrow theological bias which may lead to separate approaches to the problems of apartheid. Being "Sons of Abraham", Christians and Muslims share a basic morality which should be invoked to expose the evils of apartheid and to provide the basis for the realization of justice and equity in a future apartheid-free South Africa.

\section{NOTES}

1. See Hofmer, A.L., Islam in Nyasaland. Moslem World, 2, 1912, 3. Needless to say, the term "Mohammedanism" is obsolete and offensive to Muslims.

2. See Alpers, E.A., Towards a history of the expansion of Islam in East Africa: the matrilineal peoples of the Southern interior, in Ranger, T.O. and Kimambo, I.N., The Historical Study of African Religion, London: Heinemann, 1972, 172-201.

3. See Bone, D.S., Islam in Malawi. Journal of Religion in Africa, 43(2), 1982, 128.

4. See Delval, R., A Map of the Muslims in the World, Leiden: E.J. Brill, 1984, 14.

5. For a more comprehensive interpretation of Silveira's mission and an evaluation of its outcome see Chirenje, J.M., Portugese Priests and Soldiers in Zimbabwe, 1560-1572; the Inter-play between Evangelism and Trade. The International Journal of African Historical Studies, 6. (1) 1973, 36-48.

6. Delval, R., op. cit., 14.

7. See Lubbe, G, Islam in South Africa: Enemy or Ally? BICMURA, 3(1985), No. $1,2$.

8. Lubbe, loc. cit., 3.

9. See Lubbe, G., Islam and the State in South Africa. Unpublished paper delivered at an international conference held recently, 5 . 
10. See Karim, G.M., The Contribution of Muslims to South African Culture. BICMURA, Vol. 2, No. 1, January, 1984, 8.

11. See Davids, A., The Mosques of Bo Kaap. Athlone: South African Institute of Arabic and Islamic Research, 1980, 62.

12. Davids, A., op. cit., 110.

13. Davids, A., op. cit., 110.

14. See Fatima Meer, Islam and Apartheid. Reality (1970), 2:5, 12.

15. See Esaq, F., Muslims reject Presidents' Council. Muslim News (1980) 20:19,1.

16. See Al Quran 4:85.

17. See Lubbe, G., "Islam in South Africa: Enemy or Ally?" BICMURA, Vol. 3, January, 1985, No. 1, 8.

18. See Lubbe, loc. cit., 10.

19. Lubbe, loc. cit., 10.

20. Lubbe, loc. cit., 11.

21. Lubbe, loc. cit., 11. 


\section{African Independent Churches and their Political Roles}

Bengt Sundkler

The "African independent churches" in South Africa total about three thousand in number - nobody knows exactly how many there are at any given moment. In olden times they were referred to as "Native Separatist churches" or simply as "the sects". A book of 1948 changed this in speaking of them as "African Independent Churches", a term which proved acceptable for a time until we now find ourselves in a situation where obviously mission-related churches too are "Independent" in that they have achieved the goal which the missions had set for them, the forming of "self-governing" churches.

\section{THE "ETHIOPIANS"}

One can divide these churches into two categories, "the Ethiopians" and "the Charismatics" are such independent groups as have seceded from white missions chiefly on radical grounds, as their reaction to the racial domination which they found in the White mission. The ideological programme is "Africa for Africans" while teaching, preaching and worship largely make them into "carbon copies" of their parent Mission churches. Dr Erhard Kamphausen of Hamburg in a solid and weighty volume Anfänge der kirchlichen Unabhängigkeitsbewegung in Südafrika, 1976, has given a rich interpretation of the history of this movement until 1912. It includes a study of the foundation church on the Rand, M.M. Mokone's "Ethiopian Mission" of 1892, and also Mokone's "Declaration of Independence" in fourteen points. These include complaints about shockingly low salary conditions but above all complaints about the personal treatment which met the African pastor from his white so-called colleague: "No African pastor is honoured by the white brethren. The more the African humiliates himself, the more he makes himself a matter of derision." 
The political protest of these "Ethiopian" churches can best be followed in the case of Mokone's organisation. Having separated from the Wesleyan Methodists where he had been one of the most prominent preachers and head of the Kilnerton Institution, Mokone took another determinant step: he turned to the President of the Republic, Paul Kriiger, asking for recognition by government. Strange to say, Kriiger in a sudden fit of generosity granted this. It did not much matter that this government recognition was formulated in humiliating terms. The main thing was the fact of recognition, the more so as Mokone's competitors among the Independents tried in vain to receive these same government favours.

In 1921 Enoch Mgijuma, head of the "Israelites" or the "Church of God and Saints of Christ", established their church village, or colony, near Queenstown without having received government permission for this move. In the end five hundred fanatic Israelites hurled themselves against the machine guns of the police and one hundred and seventeen of Mgijuma's followers were fatally wounded.

This catastrophe led to the appointment of a government commission which in 1925 recommended certain conditions on which a church could be officially "recognized". They all sent their humble requests all these years, by way of annual reports to government in Pretoria, sometimes assisted by expensive lawyers, but to no avail. Over forty years after 1925, only eleven churches, naturally inclusive Mokone's church, were accepted - another indication of the neglect and contempt with which the South African government treated its law-abiding black citizens.

With regard to the political roles of the Ethiopian church movement, one can discern a scale of different attitudes from open political protest to various degrees of pragmatic adaptation. It was necessary for the churches to walk carefully. If they went too far, the controlling machinery of the government was there to check their attempts. This was brought home to Mokone's church in 1953 in connection with a popular strike against the use of government buses on the Rand. The Ethiopian church raised its protest - and the result followed immediately. The church's prestigious and valuable "recognition", enjoyed for over fifty years, was withdrawn. I have read the tearful plea from the Ethiopian church, asking for a repeal of the decision which hit the church very harshly, but their appeal was, of course, of no avail. 
Government recognition, this tool of acceptance, had become an instrument of political control.

Returning to Dr. Kamphausen's book on the Ethiopian movement "until 1912" one finds that he makes the startling assertion that the Ethiopian movement came to an end in 1912, the year of the formation of the ANC. This is startling as one thinks of the impressive new Ethiopian churches formed after this date, such as the African Congregational Church in 1917 and the Bantu Methodist Church in 1932 and a great number of others, together with the flourishing of EthiopianAbyssinian churches in the middle of the 1930s, as a protest against Mussolini's war. In Dr. Kamphausen's case this periodization is probably related to a famous theory of the church, in this case the Ethiopian church finding its fulfilment in the political party, in this case the ANC. If the facts do not correspond with the theory, so much the worse for the facts.

If, on the other hand, one allows a church to act as a religious group in its own right serving the people with its worship and sociological fellowship, then one has to take into consideration the continued existence of the "Ethiopians" until the present time.

\section{THE CHARISMATICS, OFTEN CALLED ZIONISTS}

We now move to the world of prophets and prophetesses, of visionaries and healers, those who from God have received a special revelation of their own. In this brief introduction I can do no more than mention the most intense of these groups, those of a communitas type gathered round their Prophet or Prophetess, with a community working for the leader. Their political answer is to build up a cultural identity of their own and establish a strategy, a withdrawal from the dominating world of the whites.

There is also a political protest, but more subtle than that of newspaper articles or modern political meetings. Rather they turn to traditional society and its chiefs. This at least was the strategy of Issiah Shembe and his son, Johs Galilee Shembe. In their meetings at the church's headquarters with chiefs from Natal and Zululand they could discuss problems of land and the use of land. Paulo Nzuza was related to royalty, his mother being of the Zulu clan: this was a tremendous fact in 
his life and in that of his church, its claims and pretensions: this is the stuff from which the political role of the prophet is fashioned.

The withdrawal from white society is expressed in the church's pilgrimage into the mountains. Shembe's pilgrimage takes his flock to the Inhlangakazi mountain, close to God, in the month of January. Gekwane's Church of the Light takes the followers into the hidden recesses of the Drakenberg. Here the political protest is expressed by most subtle linguistic means referring to an Exodus from Egypt and Babylon in terms which no ordinary political organiser could understand. Here they all come-labourers, truck drivers, messengers, teachers, char women, all venturing away for a week or two from the industrial world of the whites, on pilgrimage into the mountains with brooks and rivulets, Jordans and Bethesdas. The conditions of ecology help them to anticipate altogether new political roles, related to a religion close to nature, close to life and close to God. 


\section{Healing and Political Acquiescence in African Independent Churches}

Matthew Schoffeleers

It is a matter of empirical observation that healing churches lean heavily towards political acquiescence. This suggests that there exists something in the nature of a causal relation between the practice of ritual healing and the absence of political protest. Yet while we have at our disposal fundamental studies on the symbolism of ritual healing (Comaroff 1981, 1985), its role as a recruitment mechanism (Daneel 1970, 1971, 1974), and its implications for the internal dynamics of healing congregations (Kiernan 1976, 1982), there is, as far as the Southern African churches are concerned, no study on the political implications of healing. The present paper is intended to bring about a discussion on that subject.

The first question to be answered obviously is whether it can be verified that there indeed exists a postive correlation between prayer healing and political acquiescence. If this is found to be the case, the next question is how to account for that correlation. The validity of our answers depends critically on the manner key terms such as "illness", "healing" and "acquiescence" are defined, and we shall therefore begin by clarifying in what sense they are used here.

\section{DEFINITIONS}

"Illness" and "healing" have different connotations from culture to culture (Payer 1988). Terms which Westerners automatically translate as "illness", often carry a much broader spectrum of meanings in nonwestern cultures, referring not only to physical or psychic ailments but also to a range of other disorders. What V.W. Turner noted for the Ndembu of Zambia seems to hold good for African societies in general: illness is conceived of as a species of misfortune alongside such other 
species as bad luck at hunting, reproductive disorders, physical accidents and the loss of property (Tumer 1967, 300). Since it is this broader spectrum of referents which is operative in the Southern African healing churches, we shall adopt it here too, and also include experiences typical of an urban industrial society such as widespread poverty, drug addiction, alcoholism and criminality. Accordingly, "healing" must be understood as referring to the totality of activities and ideas, meant to correct or alleviate such disorders or, to use Comaroffs terminology, to reconstitute physical, social and spiritual order (Comaroff 1980, 639).

In Africanist anthropology it is customary to distinguish between three main medical systems, viz. biomedicine, "traditional" healing and spiritualist healing of the Christian or Islamic type. A recent study of mental healing in Ghana distinguishes these three systems respectively as biotherapy, sociotherapy and psychotherapy (Mullings 1984). That terminology is a useful shorthand as it brings out where the emphasis is put in each of the three systems, but it goes without saying that there is much overlap between them. In this paper we shall use the terminology which seems the more appropriate at any point in the argument.

The triadic typology is visualized in daily life by Westem-type clinics, traditional village therapists (often known by the term nganga or one of its cognates), and the numerous healing churches. It has become part also of people's perceptions of the healing facilittes which are available to them (Daneel 1970,35). ${ }^{1}$ Healing churches are defined here as churches in which healing-in the sense just described-plays a pivotal role with regard to doctrine, pastoral praxis and the recruitment of new members.

To define "political acquiescence" is perhaps more of a problem, What looks like acquiescence to one party may be described by another as a subtle form of resistance or as the best a church can do under given circumstances. We shall describe a church as "acquiescent", when its policy is to avoid political activism of a critical nature. The main emphasis is on the word "activism", for we do not claim that healing churches are never critical of the political order. They often are, but such criticisms as are being made are implicit rather than explicit, tending to justify withdrawal from that order rather than foster active resistance against it (cf. Baechler 1970; Buijtenhuijs 1976). It should be emphasized that "political acquiescence" is not meant to be a value 
judgement. Whether or not the Zionist churches in Southern Africa ought to participate more openly or more actively in the struggle against apartheid, and whether their present position is to be labeled "right" or "wrong", is not part of the present discussion.

\section{HEALING CHURCHES IN SOUTHERN AFRICA}

Although healing churches are active in many Sub-Saharan countries, nowhere are they as numerous as in the Republic of South Africa, where their number is estimated at over three thousand (Barret 1968, 22; Barrett, ed. 1983). According to the 1980 Census, the Independent Churches comprised 29.3 per cent of the African population, amounting to some five million (Adam and Moodley 1986, 199). Much of the more recent increase has probably gone to the Zion Christian Church (ZCC), which is the fastest growing healing church in the Republic, with a membership of perhaps over two million. In 1985 the ZCC caused something of a stir, nationally and internationally, by inviting President Botha to its Easter celebration, which was attended by at least half a million adherents. ${ }^{2}$

Most of the Southern African Independent Churches are healing churches in the sense defined above. These churches fulfil a need not only in relation to the relative scarcity and costliness of western medicine (De Beer 1986; Seedat 1984), but also in relation to the lack of understanding that sufferers often experience in western-style churches.

It is important also to note that healing, as practiced by these churches, means a great deal more than a capacity to solve the kind of immediate and practical problems mentioned earlier on. At a deeper level healing also functions as a metaphor for a church's capacity to cure people of what Fanon has identified as "the colonial syndrome" (Fanon 1965, 1967; Perinbam 1978) by restoring their self-confidence and reaffirming their human dignity (Kiernan 1981, 141; Adam and Moodley 1986, 201). Although the majority of the healing churches belong to Sundkler's category of "Zionist" as opposed to "Ethiopian" churches ${ }^{3}$, the terms "Zionist" and "healing" are not fully co-extensive. There are churches such as "The Apostolic Sabbath Church of God of Johane Masowe", which are generally classified as Zionist, but in which 
healing occupies only a peripheral place (Daneel 1971, 339-44; DillonMalone 1978). It is an additional aim of this paper to argue it is heuristically and analytically useful to distinguish within the Zionist group between healing and non-healing churches.

\section{THE ACQUIESCENCE OF THE SOUTHERN AFRICAN HEALING CHURCHES}

A few decades ago the assertion that healing churches are politically acquiescent would probably have sounded somewhat more surprising than it does nowadays, in view of the fact that until the late sixties it was customary in the social sciences to consider African Independent Churches primarily as instruments of people's resistance against colonialism. The main proponents of this theory were Balandier and P. Bohannan who argued that these churches served as a kind of cover-up for political resistance in situations where a colonized people had little or no possibility of founding regular political parties. ${ }^{4}$

The evidence used was that a number of Independent Churches have been active as anti-colonial resistance movements, John Chilembwe's church in the former Nyasaland being a particularly well-documented example (Shepperson and Price 1958). But Chilembwe was somewhat of an exception, and it would be difficult to maintain that the majority or even a significant section of the Independent Churches has been actively engaged in resistance against colonial governments. ${ }^{5}$ There is also evidence that in the early days the level of political involvement was higher than in more recent times and that the Independent Churches have been subject to a process of progressive depoliticisation. To quote Sundkler on the Zulu Churches:

During the period 1913-1945, the prophet's theme was protest: against the Natives' Land Act of 1913; against the domination of the missions; against the cultural patterns of the Whites in education and preservation of life. The interesting aspect of the development after 1945-48 is a tendency towards accommodation even in a culture dominated by the laws of apartheid. This accommodation can be seen in the field of private business enterprise, education and care of the sick... The prophets, in city and reserve, seemed to outbid one another in providing facilities for ritual ablutions, ensuring health and happiness. (Sundkler 1961, 306-7) 
In the Cape Colony a similar depoliticisation process had already set in some forty or fifty years earlier, when after a period of considerable optimism and political activity the independent churches under the stress of disappointment began to retreat into a pietist, other-worldly attitude (Mills 1978, 60). West, who conducted research in Soweto, confirms that in his experience the shift has generally been from the Ethiopian to the Zionist type, a process which he ascribes in part to the role played by Zionism in the process of urbanization (West 1975, 202). Further research is needed to establish whether such a shift took place in other parts of South Africa as well, but when it is realized that the instances just given come from areas as far apart as Zululand, the Cape and the Witwatersrand, it seems likely that it was indeed a more or less general process. Having established that point, we may once more address the question whether or nor our description of the healing churches as politically acquiescent is valid.

The major sources available to us with regard to the Republic of South Africa confirm these findings. After Sundkler's Bantu Prophets, which was first published in 1948, and republished in 1961, the major publications have been West's on Soweto (West 1975), Dubb's on the East Cape (Dubb 1976), Comaroffs on the Mafeking District (Comaroff 1985) and a number of important articles by Kiernan on an African Township in Durban (i.a. 1975, 1976). Other studies of direct interest are Pauw's Tswana study (Pauw 1960), Murphree's and Daneel's work on the Independent Churches among the Shona in Zimbabwe (Daneel 1971, 1974, 1988), Fogelquist's on Zionism in Swaziland (Fogelquist 1988), and Sundkler's Zulu Zion, which includes material on Swaziland as well (Sundkler 1976). In addition to these sources we have at our disposal a number of relevant comments on the political role of the independent Churches made by ecclesiastics and political scientists. As far as insights from political scientists are concerned we note the following: Mills maintains that in South Africa the contention that religious separatism was a precursor of and contributor to African nationalism is quite erroneous. "At a superficial level", so he says, "it is possible to see both sets of phenomena (i.e. separatism and nationalism) as 'resistance' to white domination and control. Nevertheless, it is clear that the two manifestations represent antipodal reactions" (Mills 1978, 51). 
David de Beer, who as a one-time staff member of the Christian Institute has a more than superficial interest in the political stance of the Independent Churches. Much as he may be inclined to give them their due, de Beer feels nevertheless that he can only describe them as "pietistic" and "politically of little significance". ${ }^{6}$ Kieman, author of a number of authoritative articles on Zionist Churches, expresses the same in somewhat more positive terms:

These gentle, peace-loving people are not engaged in a crusade of social reform. They are not intent on moving the earth by social upheaval. Nor are they the least interested in bringing about political change. At one time the Ethiopian churches aligned themselves with the aims of African nationalism, but Zionists have never espoused any political cause. ${ }^{7}$

In their recent analysis of the South African political configuration Adam and Moodley report "general and unqualified agreement among the experts" that Zionist churches avoid political commitment.

Finally, Buijtenhuijs, an authority on African resistance movements with an understandable interest in Independent Churches, characterizes the Zionist churches - in contrast to the Ethiopian variety - as anti-revolutionary countercultures, which enable their adherents to live their lives aloof from critical or subversive politics (Buijtenhuijs 1976). This aloofness and, even more so, their sometimes open collaboration with the state has caused sections of the public to regard the more conspicuous Zionist churches not as leaders but as betrayers, a feeling which on occasion has led to Zionists being molested and their houses put to the torch (Waite 1975,65$).^{8}$

Of late, when the political stance of the Zionist Churches came in for a great deal of criticism, some of their leaders at long last felt compelled publicly to defend themselves.

Thus Archbishop Ngada, president of the African Spiritual Churches Association, an umbrella organisation uniting a number of healing churches, asserted in a publication significantly entitled Speaking for Ourselves:

Our communities are sometimes accused of being too inward-looking and people ask us what we think about politics. It is difficult for us to know how to answer this question. The members of our churches are the poorest of the poor, the people with the lowest jobs or no jobs at all... Politics is not a church matter. 
People meet in our churches to pray and to worship and to experience the healing of the Spirit. They go to political organisations in order to take action against the government. Our Churches are not powerful institutions that can make statements to influence the government or the struggle (Ngada et al. 1985, 30-1).

Bishop Isaac Mokoena, Hon. Life President of the Reformed Independent Churches Association, expressed much the same opinion. ${ }^{9}$ It is a pity that we lack statistical information about the number of Zionists who have actually joined a political party or who are not opposed to joining one, but the few indications that are available suggest that their number is negligible. ${ }^{10}$ In sum, then, the opinions of theologians, social scientists and church leaders appear to be virtually unanimous.

However, there is a school of thought which emphasizes that the protest character of the Zionist Churches is implicit rather than explicit, that it is symbolized rather than verbalized, but that it nevertheless is an essential and all-pervasive characteristic. A wellknown representative of this school is Jean Comaroff, author of an authoritative study of Zion Churches in the South African Mafeking district (Comaroff 1985). In her study Comaroff shows how the adherents of these churches create for themselves a new world with the aid of African and Western culture elements, and more particularly how in that world illness and healing have been made into central metaphors. As it stands, her study is a singularly convincing illustration of Buijtenhuijs' conception of the Zionist Churches as a form of counterculture. But impressive and insightful as her analysis is, there are a number of criticisms that may be raised against it. In the first place, one has to agree with Werbner and Kiernan that the concept of "protest" as employed by her is so broad as to be almost meaningless (Werbner 1986; Kiernan 1987). Items such as the wearing of white boots and khaki uniforms by members of the Zion Christian Church, which Comaroff interprets as an expression of protest could equally well be viewed as symbols of accomodation to western values. Secondly, Zionist protest is directed as much against their fellow Africans, who do not share their convictions, as it is against whites (Kiernan 1974). Thirdly, Comaroff underplays the massive co-operation and even collaboration, which has taken place and is still taking place between some of the Zionist Churches and the South African government, a particularly telling instance being once again the enthusiastic reception given Mr. 
P.W. Botha at the ZCC Easter festival of 1985 (Schoffeleers 1988). Fourthly, even if it is agreed that the Zionist churches do constitute an important expression of cultural protest against the status quo, this need not exclude the possibility of political co-operation or even collaboration. It is arguable that the Zion Churches represent an instance of what Sumner has called "antagonistic co-operation", that is to say, cooperation between institutions or agencies that in other ways are each other's opposites." The only condition to make that type of cooperation possible is that the regime against which the protest is directed consider that protest innocuous or at least manageable. Finally, Comaroff, like everbody else, fails to notice the ambivalent character of Zionist healing. Though arguably embedded in symbolic protest, it nevertheless functions so as to discourage rather than encourage active involvement in critical politics.

\section{HOW TO EXPLAIN ZIONIST ACQUIESCENCE}

Zionist acquiescence has been attributed to a variety of factors, such as fear of state reprisals or the fear on the part of Zionist leaders of jeopardizing their chances of obtaining official recognition (Thion 1969, 28; Sundkler 1976, 282-8). Others (i.a. Ngubane 1986) have attributed the acquiescence of the Zionist churches to their otherworldly or pietistic character. Whereas the first viewpoint is perfectly acceptable - Zionist leaders have indeed been known at times to do the government's bidding in order to gain recognition - the second seems to be begging the question, for it is among other things "the otherworldly character" that has to be accounted for.

On the occasion of President Botha's controversial visit to the headquarters of the Zion Christian Church, the popular press, and more particularly the African press, cited as one of the more obvious explanations of that event the low educational level of the rank-and-file Zionist membership, thereby suggesting that lack of formal schooling is somehow to be equated with political naivite. ${ }^{12}$ The underlying accusation was of course that the mass of the Zionist faithful were being misled by their leaders, some of whom - notably those in the larger and more influential churches - had received more and better education than most of their followers. 
Archbishop Ngada, whom we have had occasion to quote earlier on, has emphasized that it was material poverty which has prevented the Zionists from becoming a political factor capable of challenging the state government. His argument is convincing to a degree, for a group's material poverty may indeed cause that group to spread its risks as broadly as possible and to be particularly careful in its handling of the state as claimant (Scott 1976). On the other hand, there are numerous examples of poverty-stricken groups deciding to rebel against the state, when in their opinion things are taken too far (Rotberg ed. 1971).

Another interesting suggestion - and one which has received too little attention - is that the Zionist churches are to be regarded as a de facto form of black apartheid, which stand to gain from supporting - or at any rate, not opposing - white apartheid. ${ }^{13}$ The apartheid laws gave many leaders of Independent Churches the opportunity they had been looking for, and one of their political advisors even suggested that those laws might well be a blessing in disguise (Sundkler 1961, 304). The theory of Zionism as a form of "black apartheid" goes a long way to explain the massive growth of African Zionism after 1948, but by itself it does not explain the political acquiescence of the Zionists, since nothing could have prevented them from engaging in some form of active protest, had they wanted to. That point is illustrated by the history of the Black Consciousness movement, which as long as it was allowed to operate could legitimately be described as a form of black apartheid. ${ }^{14}$ Yet where the Zionist Churches preached obedience to the authorities, the Black Consciousness movement was engaged in a most vociferous resistance against the apartheid state.

Finally, there is a school of thought which explains the explosive growth of South African Zionist churches over the past decade as a massive popular protest against the spiral of the political violence in the African townships. ${ }^{15}$ If so, and there is every reason to believe it to be true, one has to draw the rather ironic conclusion that the Zionist movement in South Africa has to thank its formidable expansion not only to the violence of the apartheid state but also to the violence perpetrated by its more militant opponents. However, protest against the use of physical violence by antiapartheid activists need not necessarily imply political acquiescence. The Zionist Churches could have joined the non-violent protest movement organized by leaders and members of some of the established churches, where no doubt they 
would have been made quite welcome. But they did not opt for that alternative either.

It is difficult to measure the relative importance of these various causes. It is probably true to say that their influence varies from case to case and from historical period to historical period, but that it is their combination which is the important aspect. Rejection of white culture, quest for leadership, fear of state reprisals, the search for a place to feel at home and abhorrence of physical violence have been reinforcing

ch other to the point where South African Zionism has grown into the mass movement it is to-day. To get that movement behind him would be any politician's dream and it has already been suggested by some that the ANC leadership would do wise to work on the Zionist hierarchy instead of dismissing that enourmous group as a relic of political underdevelopment (Adam and Moodley 1986, 202). Theologians too call on the Independent Churches to become more conscious of the need for political resistance against apartheid (Ngubane 1986, 81). It is doubtful, though, that this can be realized in the foreseeable future. In the first place because it is unlikely that the socio-economic environment will change drastically, leaving the Zionists the povertystricken group they have always been. In the second place-because healing itself appears to be a major obstacle to active involvement in political resistance. In other words, should they opt for the latter, healing would have to be relegated to second place.

It is to these latter observations that we now turn. The thesis is that healing, unlike the variables that we have just reviewed, is capable by itself to explain the quiescent character of the Zionist Churches. I shall argue this by providing evidence that all three medical systems, viz. the biomedical, the traditional and the zionist, foster political acquiescence, because all three tend to individualize - and thereby depoliticize-problems which are to a large extent political.

\section{SICKNESS, DEVIANCE AND POLITICAL ACQUIESCENCE}

The earliest and at the same time one of the major theoreticians in this field is Talcott Parsons, who will serve as our point of departure (Parsons 1951, 428-79). Illness, in Parsons' analysis, is a form of deviance and consequently must be viewed as a problem of social 
control. The roles which individuals must occupy in modem society often subject them to great strains and pressures resulting in failures to perform or conform. The personal troubles which result from the roles society imposes can lead to dissatisfaction and frustration. Although Parsons does not state this explicitly, the logical consequence of these strains is revolutionary action, in which individuals unite to overthrow existing social systems with their oppressive role structures. However, in his discussion of social control, Parsons hints at the revolutionary potential which the sick role helps to limit and contain as follows:

The criminal, being extruded from the company of "decent" citizens, can only by coercion be prevented from joining up with his fellow criminals... The conditional legitimation of the sick person's status on the other hand, places him in a special relationship to people who are not sick, to the members of his family and to the various people in the health services, particularly physicians. This control is part of the price he pays for his partial legitimation, and it is clear that the basic structure resulting from that arrangement is that of the dependence of each sick person on a group of non-sick persons rather than of sick persons on each other. This in itself is highly important from the point of view of the social system since it prevents the relevant motivations from spreading through either group formation or positive legitimation. It is especially important that the motivational components, which cannot be expressed in the deviant behavior itself, in this case tend to tie the sick person to non-deviant people, rather than to other deviants, unlike the delinquent gang as analyzed above. But again, the sick role not only isolates and insulates, it also exposes the deviant to reintegrative forces. (Parsons 1951, 312-3)

The sick role can thus be made into a convenient tool to maintain the status quo, and doctors, being the gate keepers who regulate access to the sick role, become thereby agents of social control.

A number of authors have elaborated on Parsons' concept of the sick role in a more critical sense by drawing attention to the pathogenic potential of the patient's social environment (i.a. Breilh 1981; Doyal 1979; Foucault 1961, 1963; Illich 1974; Krause 1977). Others have elaborated on the harmful aspects of victim blaming (Crawford 1977; Sontag 1977, 1989; Kleinman 1980). But taken as a whole, there is wide-spread agreement that Parsons' conception of sickness as a form of deviance is a useful analytical device. Consequently, it has been taken as the point of departure by all subsequent schools in the sociology of health care. ${ }^{16}$ 
Returning to the Zionist Churches we may note two important similarities and two differences. To begin with, Kiernan, one of the few to write about sickness within the ranks of the Zionists themselves, ${ }^{17}$ reports that in the twenty-two Zionist congregations in the Durban urban periphery attribution of guilt in case of sickness was an important process:

... when a Zionist falls ill it is taken to mean that somehow his membership is at risk. The aetiology of illness indicates movement across the boundary between Zionism and the secular world. If a Zionist allows himself to be caught up in outside associations and if he does so out of defiance or even through negligence, his membership is clearly wavering. Until his exact position is established through divination, the membership of a sick person, even of a sick prophet, is held in abeyance and he is debarred from exercising office and joining in Zionist work (Kieman 1976, 362).

Quite tellingly, among the same Zionists social deviance is immediately defined as illness. When a person's membership is truly weakening, the flagging member is defined as ailing, and as a patient to be treated for a temporary disability (Kiernan, ibid.)

The second similarity concerns the ambiguity surrounding the treatment of the patient. In the Zion churches this finds institutional expression in the dual role of prophet and preacher as described by Kiernan. The prophetic role is that of allocating responsibility and reward on the individual level. He apportions blame or credit, and thereby becomes a source of differentiation, not of unity. The preacher's role is that of constituting the group and reconstituting it around each fresh allocation (Kiernan 1975; 1976, 361). Constituting and allocating agents are interdependent and interact with one another, and may even be regarded as forming a partnership (Kiernan 1982, 295-6)

As to the differences, one of these is that, unlike in the Parsonian model, the patient is not reintegrated into the politically dominant culture but into a counterculture. The second is that the Zionist healing system is not directly controlled by the state. This gives it a certain degree of autonomy, but the political effect remains the same in that Zionist healing contributes to the stability of the state system as has been shown earlier on in this paper. In sum, Zionist healing conforms essentially to the Parsonian model of which it may be considered a variant. 


\section{TRADITIONAL HEALING AND THE STATUS QUO}

The traditional healing system seems to differ from the biomedical system and more especially from the system that Zionists employ in respect of their own members in that it is less inclined to hold the patient responsible for his suffering. In terms of the traditional healing system illness and misfortune may be caused also by a human or supernatural agent without the patient or his kinsmen having in any way wronged that agent. In such cases the pathogenic spirit may be exorcised or the supposed sorcerer may be forced to give restitution. African witchcraft literature is replete with instances of this kind, although it is recognized also that the sufferer himself may be at fault. Nevertheless, in many causes not he but someone else is blamed, and the question is how this relates to the Parsonian model. The answer is that where a human agent is found to have been the cause of someone else's suffering by having employed sorcery or witchcraft against him, that agent is considered a deviant in the same way that the sick person himself is in the Parsonian model. By agreeing to pay a fine or make restitution and by promising not to repeat his misdeed he is back on the road to "normality" much as the Parsonian patient is.

However, descriptions of traditional healing are important not only because they confirm once again that the politically conservative effect of healing is not something confined to Zionist churches.

\section{THE DIALECTICS OF HEALING AND CRITICAL POLITICS}

The aspect referred to is the ability of traditional healing and fertility cults occasionally to transform into political cults of a critical if not subversive character despite their erstwhile political conservatism. The historian Iliffe, when discussing the role of the Kolelo cult in the MajiMaji Rising in Tanzania, provides us with an instance. He notes that by 1905 a change had taken place within that cult from a concern with fertility and sickness to a millenarian pre-occupation, cult leaders promising the overthrow of the colonial system through direct divine intervention. ${ }^{18}$ In a comment on Iliffe's observation Ranger informs us that a similar transformation took place in cults that were active in the Shona and Ndebele Risings of the 1890's and also in the Nyabingi 
movement of Northern Rwanda and Southwestern Uganda from the 1890 's to the late 1920's (Ranger 1967, 350; also Hopkins 1971).

This transformative process appears to be reversable. When the political activities of a shrine or a medium become of marginal importance, healing may regain this former prominence. Instances of such alternating movements from politics to healing and vice versa have been noted among the Mwari shrines in the Mapoto Hills of Zimbabwe and among two important mhondoro mediums in the Zambezi Valley (Schoffeleers \& Mwanza 1977; Schoffeleers 1987; Ranger 1989). ${ }^{19}$

For comparative purposes it is interesting also to refer to a particularly illuminating case study by Rigby, who observed that in Buganda one and the same person may function as a traditional therapist and prophet, but never simultaneously (Rigby 1975). Whenever a healer adopts the prophet's role, he stops his healing practice, and whenever a person functions as a healer, he or she is no longer active in the prophetic and political sphere. Rigby, much like Horton's article on African conversion that appeared four years earlier (Horton 1971), explains this in terms of the two-level structure, which he distinguishes in Kiganda traditional religion, viz. a level encompassing its public, political aspects, and a level encompassing its more popular, local and intimate forms related to divination, healing and protection. These two distinct yet overlapping levels correspond respectively to "state" and "community".

\section{CONCLUSION}

One conclusion to be drawn from these instances of alternating offices is that the relation between healing and critical politics is not just one of mere negation and exclusion. Rather it is a relation of a more dialectical type in which these concerns alternate, the disappearance of one creating part of the conditions under which the other may emerge or re-emerge. A concern with healing may thus emerge in reaction to an emphasis on politics or vice versa, or it may function as a survival mechanism when a church or cult has lost or resigned its capacity to engage in critical politics. ${ }^{20}$

To summarize and concentrate the thrust of my argument in this 
paper, I align myself with Finkler when she concludes her suggestive paper on a Christian healing movement in Mexico:

In the final analysis, then, one can conclude that to seek folk healing of the Spiritualist kind is to seek to conserve the social order. Healing systems of the Spiritualist type are socially conservative insitutions and inherently contradictory because they tend to preserve social forms that, in the long run, may adversely affect its beneficiaries. Alteration of existing societal arrangements thus requires individuals who stand outside such movements and who have not experienced an illness that has led them to join a sectarian movement (Finkler 1986, 640).

\section{NOTES}

1. Janzen (1978) makes use of a four-fold typology by distinguishing within "traditional" medicine between two sub-types depending on the active involvement or non-involvement of a sufferer's kingroup. Since that distinction has no particular relevance to the argument to be developed in the present paper, we shall continue to use the triadic model.

2. Schoffeleers 1988. It is not entirely clear how many people attended. The organizers and government sources gave "three million" as their estimation. The Sowetan of the 12th of April, 1985, which showed itself decidedly critical of the event, thought that half a million might be closer to the truth. The majority of the press reports, however, gave estimations in between these two extremes.

3. Sundkler 1961, 53-9. In Sundkler's formulation Zionist churches are syncretistic Bantu movements, which are mainly concerned with healing, glossolalia and purification. Ethiopian Churches lay no claim to special manifestations of the Holy Spirit, and they share some of the political interests of the African nationalists. The Zionist/Ethiopian typology under that or a different name is still held to be a useful and valid distinction as far as Southern Africa is concerned (Daneel 1971; Etherington 1979, 108; Kiernan 1981, 142-3).

4. Balandier 1955; Bohannan 1964. A critical review of their theories is to be found in Buijtenhuijs 1972. Balandier and Bohannan were not the first to view the Independent Churches essentially as political instruments. That view had already been elaborated by the missionary/anthropologist Leenhardt in his doctoral thesis around the turn of the century (Leenhardt 1902). For an assessment of Leenhardt's work, se Pereira de Querioz 1965.

5. For details on the early history of Ethiopianism see Shepperson 1968 and Etherington 1979:109. The topic was popularized by John Buchan's novel The Black General (1910), which in subsequent editions was renamed Prester John after the mythical Ethiopian priest-king.

6. David de Beer, "Kerkelijk verzet tegen apartheid", in D. de Beer et al., Het uur 
van de waarheid. Het Kairos document van Zuid-Afrikaanse christenen; Baam: Ten Have (1986), pp. 8-27. This publication is the Dutch edition (with commentary) of The Kairos Document: A Theological Comment of the Political Crisis in South Africa; Braamfontein (2nd ed. 1986).

7. J. Kiernan, "The New Zion"; Leadership, vol. 4, no. 3, 1985; quoted in Adam and Moodley 1986, 201.

8. Violence against ZCC members reached a climax around Easter 1986, when it was rumoured that the minister of external affairs, Roelof ("Pik") Botha had been invited to that year's Easter celebration (The Star, March 29, 1986; The Sunday Times, March 30, 1986; The Citizen, April 1, 1986).

9. Courier Austral Parlementaire, 3rd Quarter 1985, no. 14, pp. 17-8, "The Voice of Five Million Black South Africans".

10. Thus for instance the 76 per cent of the Vapostori questioned by Murphree gave as their opinion that Christians should not enter politics, while twenty per cent held that they would ask the church for directions. Four per cent preferred to consult their family shades rather than the church, and apparently nobody was prepared to take a decision on his own. This contrasted sharply with percentages obtained from Methodists and Catholics in the same area (Murphree 1969:185).

11. W.G. Sumner, Folkways (Boston, 1906), cited in Perinbam 1978, p. 33, n. 70.

12. Reports on President P.W. Botha's visit to the headquarters of the Zion Christian Church in The Sunday Tribune, 14 April 1985, and The Sowetan, 12 April 1985.

13. Thus for instance Sundkler 1961, 304-5 and Thion 1966, 255, quoted in Buijtenhuijs 1976, 27. The same view had been expressed immediately after the tightening of the apartheid laws by the liberal weekly, The Sunday Tribune (Durban, 18 December 1949).

14. "It was a principle of the Black Consciousness Movement, at least in its early years, to exclude even sympathetic whites from participating in its activities" (Davies, et al., 1984, 304).

15. E.g. The Times, London, 9 April 1985.

16. I am relying here on Keulartz 1987, an excellent study, which discusses these various schools in extenso.

17. Most authors limit themselves more or less to the healing of outsiders, many of whom may join a Zionist Church later on. There is a difference in the way Zionists treat patients, who are still outsiders, and patients who are members of their church. In the latter case there is suspicion that the sick person has been somehow unfaithful to the church. We limit ourselves to cases of this type because of the comparison we want to make with the Parsonian model in which the patient is treated as a member of society and not as an outsider seeking admission.

18. Cited in Ranger 1967, p. 350.

19. The mediums referred to are George Kupara and Enos Pondai, respectively representing the royal Mutota spirit and the autochthonous spirit Chiwawa. Pondai, virtually unknown before the guerilla war, was jailed by the Rhodesian 
government for seven years for assisting ZANU guerillas. After the war he became a kind of national hero, and like Kupara before him, he has since built up fame as a healer. Both entered their conservative phase at the same time that they gained fame as healers (cf. Lan 1985).

20. I have come across such a phenomenon in the Mbona cult of Malawi. Although this cult is decidedly political, avoiding involvement in medical matters (Schoffeleers 1977), it happened in the course of 1960 that its main shrine came to be temporarily transformed into a healing centre. This occured at a time when the shrine organization had collapsed due to its two principal functionaries having been relieved of their chiefly status by the colonial government, seemingly to streamline the district administration. The truth, however, was that the then District Commissioner wanted to replace these two men by someone who supported the Federation of Rhodesia and Nyasaland.

\section{BIBLIOGRAPHY}

Adam, H. and K. Moodley, 1986, South Africa Without Apartheid: Dismantling Racial Domination; Berkeley: University of California Press.

Balandier, G., 1955, Sociologie actuelle de l'Afrique noire. Dynamique sociale en Afrique Centrale; Paris: Presses Universitaires de France (2nd ed. 1963).

Baechler, J., 1970, Les phénomènes re'volutionnaires; Paris: Presses Universitaires de France (1970).

Barrett, D. B., 1963, Schism and Renewal in Africa: An Analysis of Six Thousand Contemporary Religious Movements; London/Nairobi: OUP.

Barrett, D. B., ed. 1982, World Christian Encyclopedia (Nairobi/Oxford, 1982).

Bohannan, P., 1964, Africa and the Africans; Garden City N.Y.: The Natural History Press.

Breilh, J., 1981, "Community Medicine under Imperialism: A New Medical Police?", in V. Navarro ed., Imperialism, Health and Medicine; Farmingdale N.Y., pp. 149-68.

Comaroff, J., 1980, "Healing and the Cultural Order: The Case of the Barolong boo Ratshidi"; American Ethnologist, vol. 7, no. 4, pp. 637-57.

- 1985 Body of Power, Spirit of Resistance; The Culture and History of a South African People; Chicago: The University of Chicago Press (1985).

Crawford, R., 1977, "You are Dangerous to Your Health; The Ideology and Politics of Victim Blaming", International Journal of Health Services, vol. 7, no. 4, pp. $663-81$.

Daneel, M. L., 1970, Zionism and Faith-Healing in Rhodesia; The Hague: Mouton.

- 1971, Old and New in Southern Shona Independent Churches, vol. I; The Hague: Mouton.

- 1974, Old and New in Southern Shona Independent Churches, vol. II; The Hague: Mouton.

- 1976, "Independent Church Leadership South of the Zambezi"; African Perspectives (1976), no. 2, pp. 81-99. 
- 1984, "Communication and Liberation in African Independent Churches", Missionalia. Journal of the Southern African Missiological Society, vol. 12, no. 3, pp. 57-93.

- 1988, Old and New in Southern Shona Independent Churches, vol. III; Gweru: Mambo Press.

Davies, R. et al., 1984, The Struggle for South Africa; A Reference Guide; London: Zed Books.

De Beer, C., 1986, The South African Disease: Apartheid, Health and Health Services; London.

De Jong, J. T. V. M., 1987, A Descent into African Psychiatry; Amsterdam: Royal Tropical Institute.

Dillon-Malone, C. M., 1978, The Korsten Basketmakers; Manchester: Manchester University Press.

Doyal, L., 1979, The Political Economy of Health; London.

Dubb, A., 1976, A Community of the Saved. An African Revivalist Church in the East Cape; Johannesburg,: Witwatersrand University Press for African Studies Institute.

Etherington, N. A., 1979, "The Historical Sociology of Independent Churches in South East Africa"; Journal of Religion in Africa; vol. 10, no. 2, pp. 108-26.

Fanon, F., 1965, The Wretched of the Earth; Harmondsworth: Penguin (orig. French ed. 1961).

- 1967, Black Skin, White Masks; New York: Grove Press (orig. French ed. 1952).

Finkler, K., 1986, "The Social Consequence of Wellness: A View of Healing Outcomes from Micro and Macro Perspectives"; International Journal of Health Services, vol. 16 (1986), no. 4, pp. 627-42.

- 1987, "Spiritualist Healing Outcomes and the Status Quo: A Micro and Macro Analysis"; Social Compass, vol. 34, pp. 381-95.

Fogelquist, A. A., 1988, The Red-Dressed Zionists. Symbols of Power in a Swazi Independent Church; Uppsala: Research Reports in Anthropology, no. 5 (1988).

Foucault, M., 1961, Histoire de la folie à l'age classique; Paris.

- 1963, Naissance de la clinique; Paris.

Gluckman, 1965, Politics, Law and Ritual in Tribal Society; Oxford: O.U.P.

Hahn, R. A., 1984, "Rethinking 'Illness' and 'Disease"', Contributions to Asian Studies, vol. 18, pp. 1-23.

Hopkins, E., 1971, "The Nyabingi Cult of Southwestern Uganda"; in Rotberg, ed. (1971), pp. 60-132.

Horton, R., 1971, "African Conversion"; Africa, vol. 41, pp. 27-40.

I.A.M.S., 1985, Christian Mission and Human Transformation, Report of the Sixth IAMS Conference, Harare, 8-14 January 1985, in Mission Studies, Journal of the International Association for Mission Studies, vol. 2, No. 1

Illich, I. I., 1977, Limits to Medicine. Medical Nemesis The Expropriation of Health; Harmondsworth: Penguin.

Keulartz, J., 1987, Van bestraffing tot behandeling. Een inkiding in de sociologie van de hulpverlening; Meppel: Boom. 
Kieman, J. P., 1974, "Where Zion Draws the Line"; African Studies; vol. 33, no. 2, pp. 79-90.

- 1975, "Old Wine in New Wineskins; A Critical Appreciation of Sundkler's Leadership Types in the Light of Further Research"; African Studies, vol. 34, no. 3, pp. 193-201.

- 1976, "Prophet and Preacher: An Essential Partnership in the Work of Zion"; Man (n.s.), vol. XI, no. 3, pp. 356-66.

- 1981, "Themes and Trends in the Study of Black Religion in Southern Africa"; Journal of Religion in Africa, vol. 12, no. 2, pp. 136-147.

- 1982, "The Problem of 'Evil' in the Context of Ancestral Intervention in the Affairs of the Living in Africa"; Man (n.s.) vol. 17 (1982), no. 2, pp 287-301.

- 1987, Review of Comaroff 1985 in Africa, vol. 57 (1987), no. 1, pp 131-2.

Kleinman, A. M., 1980, Patients and Healers in the Context of Culture; Berkeley: California University Press (1980).

Krause, E. A., 1977, Power and Illness. The Political Sociology of Health and Medical Care; New York.

Lan, D., 1985, Guns and Rain; London: James Currey.

Leenhardt, M., 1902, Le mouvement e'thiopien au sud de l'Afrique de 1896 à 1899; Cahors (republished by R. Comevin 197516).

Mills, W. G., 1978, "The Fork in the Road; Religius Separatism and Nationalism in the Cape Colony, 1890-1910"; Journal of Religion in Africa, vol. 9, no. 1, pp. $51-61$.

Mullings, L., 1984, Therapy, Ideology and Social Change: Mental Healing in Urban Ghana; Berkeley: University of Califomia Press.

Murphree, M. W., 1969, Christianity and the Shona; London: The Athlone Press.

Ngada, N. H. et al., 1985, Speaking for Ourselves; Braamfontein: Skotaville Publishers, pp. 30-1.

Ngubane, B., 1986, "Theological Roots of the African Independent Churches and Their challenge to Black Theology", in Itumeleng J. Mosala and Buti Thlagale, eds., The Unquestionable Right to Be Free; Essays in Black Theology; Johannesburg: Skotaville Publishers, pp. 71-90.

Oosthuizen, G. C., 1968, Post-Christianity in Africa; A Theological and Anthropological Study; London: Hurst and Co.

Parsons, T., 1951, The Social System (Glencoe, 1951).

Pauw, B. A., 1960, Religion in a Tswana Chiefdom; London: O.U.P.

Payer, L., 1988, Medicine and Culture. Varities of Treatment in the United States, England, West Germany and France; New York: Henri Holt and Company.

Pereira de Queiroz, M. I., 1965, "Maurice Leenhardt en les kglises éthiopiennes"; Le monde non-chre'tien, no. 74, pp. 67-83.

Perinbam, M. P. B., 1978, "Violence, Morality and History in the Colonial Syndrome: Frantz Fanon's Perspectives", Journal of Southern African Affairs, vol. 3, no. 1, pp. 7-34.

Ranger, T. O., 1967, Revolt in Southern Rhodesia, 1896-7; London: Heinemann.

- 1989, "The Politics of Prophecy in Matabeleland", Satterthwaite Colloquium on African Religion and Ritual, April 1989. 
Rigby, P., 1975, "Prophets, Diviners and Prophetism: The Recent History of Kiganda Religion"; Journal of Anthropological Research; vol. 31, pp. 116-48.

Rotberg, R. I., ed., 1971, Rebellion in Black Africa; London: Oxford University Press.

Saunders, C., 1978, "African Nationalism and Religious Independency in Cape Colony. A Comment"; Joumal of Religion in Africa, vol. 9, no. 3, pp. 207-10.

Schoffeleers, J. M., 1977, "Cult Idioms and the Dialectics of a Region", in R.P. Werbner ed., Regional Cults (London, 1977), pp. 219-39.

- 1979, "An Organizational Model of the Mwari Shrines", in J.M. Schoffeleers ed., Guardians of the Land; Gwelo: Mambo Press, pp. 297-315.

- 1987, "Peasants, Mediums and Guerillas", Journal of Southern African Studies, vol. 14 , no. 1 , pp. 147-52.

- 1988, "The Zion Christian Church and the Apartheid Regime"; Leidschrift (Leiden), vol. 4, no. 3, pp. 42-57.

Scott, J. C., 1976, The Moral Economy of the Peasant; New Haven: Yale University Press.

Seedat, A., 1984, Crippling a Nation: Health in Apartheid South Africa; London.

Shepperson, G., 1968, "Ethiopianism: Past and Present"; in C.G. Baeta, ed., Christianity in Tropical Africa; London: O.U.P. for the International African Institute, pp. 249-64.

Shepperson, G. and T. Price, 1985, Independent African; John Chikmbwe and the Origins, Setting and Significance of the Nyasaland Native Rising of 1915; Edinburgh: The University Press (2nd ed. 1987).

Sontag, S., 1977, Illness as Metaphor; New York (1977).

- 1989, Aids and Its Metaphors; New York (1989).

Sundkler, B., 1961, Bantu prophets in South Africa; London: Oxford University Press (2nd ed.).

- 1976, Zulu Zion and Some Swazi Zionists; Uppsala: Gleerups with the O.U.P.

Thion, S., 1969, Le pouvoir pak: essai sur $k$ systeme sud-africain; Paris.

Turner, V. W., 1967, "Lunda Medicine and the Treatment of Disease", in V.W. Turner, The Forest of Symbols; Ithaca: Cornell University Press, pp. 131-50.

- 1975, Revelation and Divination i Ndembu Ritual; Ithaca: Cornell University Press.

Waite, G., 1975, "The Socio-political Role of Healing Churches in South Africa; Ufahamu, vol. 6, no. 3, pp. 58-67.

Waitzkin, H. B. \& B. Waterman, 1974, The Exploitation of Illness in Capitalist Society; Indianapolis.

Werbner, R. P., 1985, "The Argument of Images: From Zion to the Wilderness in African Churches"; in W. van Binsbergen and M. Schoffeleers eds., Theoretical Explorations in African Religion; London: Kegan Paul International, pp. 253-86.

- 1986, "The Political Economy of Bricolage", Journal of Southern African Studies, vol. 13, no. 1, pp. 151-6.

West, M., 1975, Bishops and Prophets in a Black City; African Independent Churches in Soweto, Johannesburg; Cape Town: David Philip with Rex Collings, London. 


\section{A New Religious Political Right one Gustafsson}

In this paper I give some preliminary results of my comparative study of the Rhema Bible Church (RBC) in South Africa and Livets Ord (the Word of Life) in Sweden, respectively. ${ }^{1}$ I will highlight certain features in the way in which RBC exploits modem communication technology. I will also explore certain covert and overt political emphases in the message of this new religious movement. The RBC might be consistent as to it's theology, internationally. One question is how this theology applies to two different cultures, South Africa and Sweden.

This paper sets out to identify certain features in the picture of South Africa disseminated by the RBC outside the country and to shed light on its orientation towards South Africa's television media. The RBC's interest in using the media, nationally and internationally, is then related to its political standpoint.

In the 1980s a new actor has appeared in South African church life, with strikingly strong political ambitions. It is the media-based Rhema Bible Church (RBC), founded in 1979 by Ray and Lyndie McCauley. The members of RBC in 1986 were $8,600 .^{2}$ In my intenviev with Ray McCauley in April 2, 1987, he gave the tentative figure of 11,500 members. ${ }^{3}$

\section{THE RHEMA REPRESENTATION OF SOUTH AFRICA AT THE INTERNATIONAL LEVEL}

The Randburg RBC is one in an international network of such churches. It is justifiable to speak of three geographical anchor points: Randburg in South Africa, Uppsala in Sweden, and Tulsa in the United States. We will concentrate first on the picture conveyed by Randburg RBC in the US and Sweden of the situation in South Africa. This type of material is very characteristic for RBC and RBC-related activities, and South African authorities prove to be most appreciative of RBC media products. Let us begin by examining three different types of media material that have been used in different countries. 


\section{Videos for Great Britain and the United States}

I start with some comments on a video film produced by a South African travel agent called Good News Travel Promotions, based in Johannesburg. ${ }^{4}$ The people taking part in the film We see a New Africa, are Christians, who give their views on the situation in South Africa, directly and in reply to questions. It is of particular interest that three well-known pastors in the Rhema movement and the International Fellowship of Christian Churches (IFCC) appear on the video: Ray McCauley, Moso Sono and Nicky van der Westhuizen. ${ }^{5}$

The video was produced in 1986 by Eugene de Villiers, himself a member of the New Covenant Fellowship. It has been used in connection with organized visits to the US. In 1986 de Villiers took a group of black leaders, who said they supported change, but were against sanctions. They were invited to the White House. The trip, which cost 86,000 Rand, was financed by de Villiers himself and by private enterprise. Its main purpose was to stop sanctions, and the party visited US senators. ${ }^{6}$ It is set in a context where the purpose is to prevent sanctions against South Africa. Rhema thus figures in political lobbying.

A similar video, The Other South Africa, has also been shown to churchgoers in the United States, in private homes and in certain churches. ${ }^{7}$ It was produced in 1986 . It has been used by groups from South Africa visiting churches and political institutions in the US.

The brochure accompanying the video We see a New Africa, presents a one-sided and propagandistically favourable picture of South Africa:

In a world where morals and standards are plummetting, and nations seem to be on an irreparable slide toward spiritual darkness - South Africa appears a beacon of hope and promise.

Here is a nation that still by and large seeks to uphold conservative values, and to encourage its people to love justice and truth. Here is a nation that is not ashamed to honour God and to mention His Word, both officially and informally. It has a spiritual heritage that has passed down from the pioneer forefathers, through the generations, and today lies in the very fabric and foundation of its people. $^{8}$

Against this background the message of We see a New Africa is clear.

a. The video favours the violation of boycotts of South Africa. 
b. The presentation of the South African situation is highly selective, and reference is made to special "Christian" knowledge and to what can be termed the tourist picture of South Africa.

c. The perspective through which the propagandist chooses to appeal to the audience's basic values is a sort of all-embracing unquestionable Christian view of existence.

In my opinion, the overall interpretive framework is provided by the category of God and the things perceived as being done by God. There is a propagandistic purpose, to get people to apply this particular pattern as they view the situation in South Africa. The perspective is one that sees everything in life as a spiritual course of events. On the basis of this underlying position, a political message is issued: the boycott should be disregarded. The interpretation of Christianity thus is both theological and highly political. The same holds true for the campaigns of Reinhard Bonnke, where RBC, too, is involved. ${ }^{9}$ It includes both a basic religious view and an ideological/political message.

\section{The Bonnke campaigns in Europe}

My second example of religious media products where the RBC is involved is connected with Reinhard Bonnke's activities. Bonnke has set up his headquarters in Frankfurt in West Germany, from which he arranges large-scale campaigns in Africa and Europe. ${ }^{10} \mathrm{He}$ is specialized in organizing massmeetings. Bonnke's move to West Germany naturally does not mean that his political role in South Africa has diminished. He operates as South Africa's spiritual ambassador in Frankfurt, and it is in that function that he was being invited to Ralingsås, Sweden, in June 1989.

Ray McCauley whom we met in We see a New Africa says that he often works together with Reinhard Bonnke. McCauley comments on his relations with Bonnke in my interview with him in 1987:

Yeah, Reinhard and I are best friends. I see his ministry as valuable and as precious as ours. We've treated his ministry as ours and I think one of the unique things that-God did for us is that, instead of duplicating his ministry, we received his ministry. So, you know, I think one of the problems we have today is we keep duplicating. If you're not part of my denomination, then we must have this, you see. And we see that Reinhard's doing the job for Africa. Let's rather give him the 
money, let's rather give him the know-how, let's rather give him everything. And our relationship's developed very strong through that. And I see him as one of the greatest evangelists on the face of the earth today. I see him as the, as one of the key men for Africa, and which my heart is really in, and we travel around the world a lot together and minister together. ${ }^{11}$

The financial link between the RBC and Bonnke's work is a strong one. Concerning the funding of Bonnke's work, McCauley says: "Yes, very much so. What we do is, as a church we take ten per cent of our income and put that straight into helping missions and missionary work." ${ }^{2}$

The Rhema Bible Church supports Bonnke's work financially, with personnel, and in other ways. Ray McCauley appeared as a speaker at Bonnke's conferences in Harare in 1986, in Frankfurt in 1987 and in Birmingham, England, in 1988. At the 1987 conference in Frankfurt, the RBC's magazine Eagk News was distributed. The issue that was handed out is of considerable interest from the source critical point of view. Paul Gifford notes this magazine and in particular the prophecy recorded in it. Gifford perceptively interprets certain expressions as referring to the ANC: ". . . I have brought to nought the plans of the fathers of anarchy. I have destroyed the sons of anarchy and am releasing My people." According to this prophecy, God is perceived to be opposed to the ANC, and the threat against South Africa is that of communism. ${ }^{13}$ It was this magazine that was distributed in Frankfurt at Bonnke's European conference. The threat portrayed is traditionally South African, and the enemy is the ANC.

What is of greater interest, however, is that certain parts of the prophecy, which was originally brought forth during the IFCC conference at the Randburg RBC in March 1987, are not included in Eagk News. This prophecy is recorded on a cassette tape from Celebration 1987. ${ }^{14}$ A source critical analysis shows that sections have been deliberately omitted. Let us look at one instance of this omission.

Throughout the prophecy, there is an emphasis on the chosen people. "I am going to establish and manifest the authority and power of My Kingdom in such a way that the nations of the earth will wonder." 15 The following section, connected with this passage, is omitted from the version finally published:

You understand me when I say to you that you are people that knew the power of laager and the defence of laager, but know I've caused nations to laager you and because they are laagering you and because you are (...) it's in my purpose, it's for 
the fulfilment of the ushering in of a manifestation of my kingdom because you will know a stronger economy because I laager you in and there the nations that are now holding you in, are thinking that they will bring my kingdom to nought in this particular nation, I want you to understand that it is in my plan, it's in purpose because by their very doing of this their economy break down that's coming among the western nations will not touch you. ${ }^{16}$

The crucial points in this prophecy are concentrated round the ideology of huger. One possible interpretation is that when Biblical support for apartheid is no longer provided by the DRC, for example, the Rhema Bible Church and the IFCC take up the old, loaded terms about themselves as the chosen people and speak in terms of paramilitary structures - the huger. This presumably means that these prophecies are assigned the role of legitimating inequality and hierarchy as a manifestation of God's will.

Why are such sections omitted? It is possible that some of the most sublime expressions of support for those in power in South Africa must be reserved for the more internal media-consuming élite within the RBC and IFCC. ${ }^{17}$

In this way Bonnke's campaigns provide a plattform for South African evangelists who in the form of prophecy convey propagandistic support for the case of White South Africa.

\section{Message for Sweden}

The third example of the dissemination of information about South Africa involves a Swedish journalist, Ingemar Myrin, who studied together with his wife at the Rhema Bible Training Centre in Randburg in the academic year 1985186.

Mr Myrin is a key link between the Rhema movement in South Africa and the Word of Life movement in Sweden. He published a series of articles about South Africa in the newspaper Trons Värld in 1988. ${ }^{18}$ The first, with an anti-communist slant, deals with Ndabezinhle Musa. ${ }^{19}$ Myrin makes use of material produced in South Africa by Women For South Africa. This organization can be viewed as one of the most clearly right-wing organizations in South Africa. The same material is available in printed form, with drawings, with the title "Ndabezinhle Musa, The True Story of a 'Freedom Fighter'". 
Let us examine a lecture mr Myrin gave in Uppsala for Women's Aglow on 13 October $1987 .{ }^{20}$ The title of the lecture was "What God is doing in South Africa today ${ }^{\mathrm{v}}$. Significant features are:

a) Media coverage of South Africa is selective and one-sidedly negative:

- Journalists only try to report unfavourable events.

- We must be aware that those working in the media today cannot hear what God is saying.

- We are fed with the bad news from South Africa.

- The work which the Holy Spirit is doing is something you are unlikely to read about in the Swedish press.

b) The Role of the Church is defined in terms of the New Religious Political Right: ${ }^{21}$

- Christians are urged to be active in South Africa.

- God is now raising up various gifts and ministries in his Church, with a strong prophetic mission at this time.

- There is a need for Christian schools in South Africa, to provide a new outlook and uphold human dignity.

- The boycotts now mean, for example, that Bibles cannot be distributed. Bible dissemination has been reduced by half.

- We must change political structures from within, through transformed people who transform their society.

- 80-90 per cent of blacks do not want a boycott.

c) The Epistemology is elitist:

- Christians have a source of knowledge of their own concerning the situation in South Africa.

- We need a renewing of our minds in the Holy Spirit, so that we do not see the world with the eyes of the media. Some people believe more in what newspapers and television say than what God's Word and the Holy Spirit tell us about the things happening in the world.

d) The Cosmology is distinctly dualistic:

- The struggle is not against people and views, but against demonic powers that control and lay waste.

We have examined three different types of media material; videos, massmeetings and lectures, that have been used in different countries. 
This way of perceiving and presenting the situation in South Africa recurs in the Rhema Bible Church in South Africa, Great Britain, the United States, Europe and Sweden. On this particular issue the RBC theology/ideology is consistent.

\section{THE RHEMA MEDIA STRATEGY IN SOUTH AFRICA}

There is a discussion going on within missiology of new communications technology and the Church's relationship to it in an historical perspective. New technology has emerged, especially in the media field, and an issue of interest to the missiologist is how the churches relate to it.

The SABC (South African Broadcasting Corporation), the exclusive state media monopoly for almost all radio and all television in South Africa, acts as an extension of the state. What is, then, the relationship between the Rhema Bible Church and the SABC?

In the 1980s the South African government has broadend the scope of security to enclose also information and publication. In 1982 the Internal Security Act was introduced. As far as media policies are concerned conditions are spelled out in the Protection of Information Act. Newspaper publishers and journalists who publish confidential information or official documents can be sentenced to 10 years' imprisonment or heavy fines. The government is empowered to prevent publication of any type of information which it deems sensitive.

The Publications Act contains most of the regulations affecting freedom of expression in South Africa. It covers a very wide range of objects: t-shirts, slogans, films, audiotapes, videotapes, song lyrics, plays, cabaret skits, even government broadcast material are all subject to banning, as well as the obvious political speeches, books, socially critical novels and works of scholarship. ${ }^{22}$

Against this background the access of RBC to S A television media is worthy of note. It seems, in fact, to be of mutual benefit for both the RBC and S A government. Specially agreed television time enables the $\mathrm{RBC}$ to proclaim its message. By allowing RBC such access to the TV, with its individualizing and passivizing view of Christianity, the authorities are ensuring loyal support for their "reform programme".

McCauley reveals in my interview with him, that in a conversation 
with State President P. W. Botha, he discussed media strategy and the possibility of access to South African television:

He invited all the Pentecostal churches and us and me representing the new churches. And the day before that, then they had the historical churches there to put over their grievances, and to put over what they felt should be done by the government. (...) I haven't got a very close relationship with the President. I think that he knows what we do, he knows what's happening, he knows what we believe. But again, you see, scripturally, it says that you need to pray for your government and everybody in authority, and that's about, is very difficult to do, when you have all different people in the congregation who have problems. But we do that because we believe the Bible and we give the respect to any president or prime minister, but I don't necessarily agree with all that he says, and I don't agree with what any politician totally does and say. But when I saw him, what I asked for was, I felt that, Reinhard was still in the country (...) and I felt that they have neglected a lot, to a degree, the message of the new birth. And I would've, you know, because what we have, I think, is like what you might have overseas. If you have the Lutheran Church dominate the television and every. thing, it's difficult then to see people's hearts changed. And so we spoke to him on that level. But he is a confessed Christian, who believes and was gonna be a missionary. But coming from an Afrikaans background, you need to realize the culture, and the way of thinking was, you know, that apartheid was scriptural. Now I think they're beginning to realize that that wasn't right. And I just hope that the reform is quick, and that a lot of the things they ['ve] promised to do, they'll do. (...) He knows a lot of Scriptures, spends at least half an hour to an hour reading the Bible and prayertime by himself. And his reaction was very much that that's what he believes. That's one of the areas, but politicians it's difficult to get very much into a dominant Christian aggressive stand, you know. ${ }^{23}$

The State President is given the status of being a Christian with a very active devotional life. McCauley is careful to give Botha this Christian legitimation. At the same time he stresses that the President knows about the Rhema Bible Church and what it does and believes in. In this way, the RBC receives a kind of legitimation from Botha. There thus emerges a mutual legitimation in connection with McCauley's appeal for television time.

The RBC and the IFCC want access to the media, and access to the media they have been given. Pastor Edmund Roebert from Hatfield Christian Church mentions this at the IFCC's convention that was held at RBC in 1987:

We as churches across the nation are being playing once a month and I want to tell you that's a part of our becoming a people of destiny. If you miss any other 
services during the month don't miss that prayertime and I would like a couple of statements I always wish the tape wasn't on but within three hours of our churches across the nation prayed some month back a plane crashed and wicked men were exposed for what they are as a result of our people praying across the nation the media has open in a way which I been impossible for six months ago I don't even want to tell you all the details I am afraid to tell you all the details but I have never dreamed it will open that quickly you don't know the details, just watch your screens. ${ }^{24}$

Here Roebert mentions how God, in answer to prayer, allowed an aircraft to crash and how access to the media has been drastically opened up to the IFCC. God is seen to be behind violence directed against those who are defined as enemies, at the same time as prayer has opened up the South African media.

Access to the media was in fact one of the main reasons for the founding of the IFCC, I claim. Broadcasting time on the SABC was one of the IFCC's objectives, perhaps the objective. ${ }^{25}$

Ray McCauley was invited to minister on six of the "Good Morning South Africa" opening prayer services on the SABC in 1988 and the SABC's Christmas Day service was broadcasted by the Rhema Bible Church. ${ }^{26}$ The RBC's youth pastors, Rob Harmon and Bruce Weyers, have been presenters on a television programme for young people, "Built for Life". In the RBC's internal monthly newsletter, they describe the content of the programme and their relationship to the SABC:

Pastor Rob and I would like to thank all the people that have been praying for the programme "Built for Life" and ourselves. We have seen a great number of young people ministered through the programme with needs such as homosexuality, lesbianism, broken homes, loneliness, relationship problems and being unsaved. We have received a tremendous encouragement from the SABC Religious Department and are really looking forward to the coming months as we deal with topics such as suicide and forgiveness. ${ }^{27}$

In Rhema, the authorities have found a church that emphasizes an extreme form of individualism. The Rhema Bible Church's access to and use of the media is to the advantage of both parties in this manoeuvring for the state-controlled media. The RBC has the advantage of being able to work at a spiritual level, and the Government thus receives support for its political action.

It is within such a framework that the political message of RBC should be understood. 


\section{THE POLITICAL FUNCTION OF THE RHEMA BIBLE CHURCH}

Is the Rhema Bible Church an example of the New Religious Political Right in South Africa?

The Rhema Bible Church is, certainly, known for its multi-racial worship, but in terms of its membership it is a mainly white church. McCauley says that 80 per cent of its members are white and 20 per cent black. ${ }^{28}$ We may assume that a very limited number of black people are involved in leadership and financial administration.

McCauley's view of politics includes activism and the threat of Socialism. At the same time as he denies the existence of segregation within the RBC, he advocates members voting in the election, which only some of the congregation are able to do. This inconsistency is voiced openly. Furthermore McCauley advocates negotiations as a means of achieving a political solution as do all other Christian leaders, but he, unlike others, considers Inkatha's leader, Gathsa Butholezi, as a valuable example of this approach. ${ }^{29}$ Gathsa Butholezi plays the role of being a violent tribalist, according to some critics.

A new source of theological support for the present apartheid regime since the DRC has modified its traditional support for apartheid is to be found in the RBC. The former ideological support for the policy of segregation is now suspended. Instead new prophetical messages are heard from American guest speakers and their local interpreters or from South African ministers. ${ }^{30}$ A particular part of such messages is a rhetoric rejection of policies of economic sanctions against the apartheid regime. ${ }^{3}$

Indeed, Ray McCauley declares openly that he is opposed to sanctions.

Yes. I am against sanctions. The reason being is that I think a lot of peoples look at the problems rather than trying to find a solution. [If] I sat down with you today, I could spend two hours telling you the problems, that the Blacks are treated bad here, the Afrikaner's wrong there etc., and etc., and etc. But what I would like to see more of is what are the solutions to the problems. And I don't think sanctions is, because I think sanctions breeds poverty, it breeds hurt, it breeds a lot of disharmony. We have to feed the Blacks. I know what I'm talking about. We feed up to 80 people a day. They come here because they haven't got jobs, and they're suffering, badly, and I don't think it's the answer. I think the answer is, is to seek constructive engagement. Some people say it hasn't worked and that's why they're going to the second level, which is sanctions. I disagree. I 


\section{A new religious political right}

think that if we can keep on working and sitting down and going through things and doing positive things, you see. I'd rather see people overseas send a lot of money to help the Blacks then, to help their education, to give them bursaries, to give them financial help, to feed them. OK, leave the Whites out of it, but, but sanctions just cuts the Blacks off too, and I can't see hurting the person that you're trying to help being the solution. ${ }^{32}$

The term constructive engagement, which has been so central to American foreign policy relating to South Africa, is emphasized in this US-oriented missionary movement. Being against sanctions means being for the privileged people.

\section{Political interdenominationlism}

In 1988 the Rhema Church was involved in the formation of a new interdenominational organization, the Church Alliance of South Africa (CASA), which claims to be an alternative to the South African Council of Churches (SACC). CASA's leadership includes the Rev. Ron Steel from the RBC, Pastor Marthinus Badenhorst from the Full Gospel Church of God, and former Soweto mayor and preacher, David Thebehali. ${ }^{33}$

The International Fellowship of Christian Churches is one of its member organizations. CASA defines its purpose as being

To present a united Christian voice, which would be a voice of moderation on vital issues which face the nation of South Africa, whether spiritual, moral or social. To promote peace, justice and goodwill among all men by means of peaceful negotiations and dialogue. ${ }^{34}$

Regarding its immediate objective, the Alliance writes that it is seeking to "counter the sanctions and disinvestment campaign against South Africa". ${ }^{35}$ Its strategy refers to particular target groups which the organization wishes to reach:

To meet and talk with overseas political leaders to impress upon them the dangers of sanctions which could cripple the nation and have far-reaching political repercussions for the whole of the sub-continent of Southern Africa.

To meet and talk with business leaders, to encourage them to invest and help build South Africa into a strong and prosperous nation, which would have a positive spin-off in South Africa. ${ }^{36}$ 
CASA lends its support to the process of certain political reforms:

That CASA can be an effective force to bring moderation to prevail in South Africa while the political reformation takes place.

That by presenting a strong, united voice of moderation, overseas opinions will become more positive and overseas investors encouraged to become part of the solution to building what may be termed a "new South Africa". ${ }^{37}$

These preliminary hints provide the basis for the following tentative suggestions: the RBC is pliant towards those in power and independent in relation to the enemies. The Nationalist Party's so-called reform policies are legitimized by religious means. The religious symbols and expressions serve a political function. Yes, there is a new Religious Political Right in South Africa. If the DRC used to be the best supporter of the apartheid "system", this may not any longer exactly be the case. Instead the Rhema Bible Church with its advanced involvement in media production has emerged as a new and strong force legitimacing the power apparatus of South Africa, nationally and internationally. The RBC is obviously in favour of a privileged society, regardless of the skin of the privileged people. Still, the privileged ones in South Africa happens to be, of course, the whites.

\section{NOTES}

1. See further O. Gustafsson, "Omen har landat.-Utkast till ett forskningsprojekt." SMT 1987:3, pp. 45-59. I paid my first visit to South Africa to gather material in spring 1987, when I had the opportunity to interview several leaders of the Rhema Bible Church (RBC) and to collect cassette tapes and other source material. Briefer visits in 1988 and 1989 enabled me to collect further material.

The material in the present paper is only a small fraction of the large corpus which forms the basis for my work and which will be presented in a forthcoming dissertation in missiology at Uppsala University. The material concerned is of various types, including interviews, cassette tapes, videos, and printed material published by various organizations.

2. On his video-tape The Other South Africa Ray McCauley says: "We started just over six years ago in a house with 11 people and my wife and myself, which makes 13. And we have had over 100,000 people been born again just in our local church. We have a membership of 8,600 right now". Videocassette, The 
Other South Africa, produced and directed by Steven B. Stevens, post production The Film House/ Cincinnati, A World Witness Production, 1986.

3. Interview with Ray McCauley 2 April 1987, Randburg. McCauley emphasizes that the figure 11,500 includes children of members of RBC.

4. We See a New Africa. Video produced by Good News Travel Promotions, 1986.

5. Ray McCauley and Nicky van der Westhuizen are among the founders of the IFCC, which was officially launched at a meeting in Durban in August 1985. Steele R., A biography. Ray McCauley Destined to Win. Cape Town 1986, pp. $113 \mathrm{ff}$. Moso Sono is a pastor in the Grace Bible Church in Soweto and a member of the IFCC.

6. Interview with Eugene de Villiers, 1 April 1987.

7. Interview with Russell Eggert in Cape Town, 8 May 1989.

8. We see a New South Africa. Brochure produced by Good News Travel Promotions.

9. Reinhard Bonnke is the leader of the organization Christ for All Nations which is now based in Frankfurt. When still operating in South Africa Bonnke was a founding member of IFCC.

10. Paul Gifford has carried out a content analysis of Reinhard Bonnke's sermons in Harare in 1986: "'Africa Shall Be Saved'. An appraisal of Reinhard Bonnke's Pan-African Crusade", in Journal of Religion in Africa, xvii, 1, 1987.

11. Interview with Ray McCauley in Randburg, 2 April 1987.

12. Ibid.

13. Gifford P., The Religious Right in Southern Africa. Harare 1988, p. 40.

14. Celebration 1987 Prophecy Tape. Tape 15 Cel 0415. This cassette tape is sold by the Randburg RBC.

15. Eagle News, May-July 1987, p. 6.

16. Cekbration 1987 Prophecy Tape. Tape 15 Cel 0415.

17. I will explore this problem concerning the role of prophecy in my forthcoming dissertation.

18. As regards its contents, the periodical Trons Värld is very closely related to the Swedish Rhema movement.

19. Trons Värld 1988:9, p. 12.

20. The subject of the lecture was advertised under the heading of "What God is doing in South Africa today". It was held at Hotel Gillet on 13 October 1387. Tape recording in author's possession. Women's Aglow corresponds to Full Gospel Business Men International, and organizes women in much the same way.

21. The term "the New Religious Political Right" is here used without any qualifying or defining it more exactly.

22. Phelan J. M., "Cultivated Babel: South Africa's apartheid media." In Media Development 311985, p. 7.

23. Interview with Ray McCauley in Randburg, 2 April 1987.

24. Celebration 1987, Prophecy Tape, Tape 15 Cel 0415.

25. Steele R., A biography. Ray McCauley Destined To Win. Cape Town 1986, p. 115. 
26. Eagle News, Fourth Quarter 1988, p. 11.

27. Rhema News, May 1988.

28. Interview with Ray McCauley in Randburg, 2 April 1987.

29. Ibid.

30. See for instance Benny Hinn's statement published in the Eagle News, Fourth Quarter 1988, p. 10.

31. Celebration 1987 Prophecy Tape. Tape 15 Cel 0415.

32. Interview with Ray McCauley in Randburg, 2 April 1987.

33. New Nation, 8 January 1989, Vol. 5, No. 1.

34. Church Alliance of South Africa, Memorandum.

35. Ibid.

36. Ibid.

37. Ibid. 


\section{The Theological Debate on Liberation}

\section{Per Frostin}

The debate between Christians with divergent views on liberation is an important dimension of contemporary theology. The purpose of this paper ${ }^{1}$ is to discuss two different theological interpretations of liberation with special reference to Namibia.

Two questions will be of special importance:

*

How is the relation between God and the world as well as between the secular and the sacred perceived in the analyzed positions?

* What is the role of the Christian community in what may be called the project of liberation? This phrase is here used in a broad sense to denote the attempts of movements and persons to promote freedom and justice by a political praxis.

Discussing the first question, we will differentiate between two options characterized as dualism and holism. First it is important to clarify the meaning of the concept of dualism since it is used in different ways. Sometimes it implies a world-view which highlights the struggle between good and evil, and between justice and injustice. A more common use, however, is to refer to an alleged dichotomy between spirit and matter, between church and world, between the sacred and the secular or between God and humanity. Here we use "dualism" in the latter sense.

Few Christians would dispute that there is a conflict between good and evil. A dualistic interpretation of the relationship between the church and the world, or between the sacred and the secular is debatable, however. Generally speaking, it corresponds with the common saying that "one must separate church and politics". As a consequence, a theological critique of injustice in social, political and economic structures is deemed as illegitimate. If the question of liberation and Christian life are related to two different spheres, it is impossible to formulate a theology of liberation. In a dualistic perspective such a 
theology is understood as a mingling of two different spheres of competence.

A holistic approach, by means of contrast, is characterized by not distinguishing between different spheres of competence but seeing reality as a differentiated totality.

In the analysis of the second question we will also discuss two positions, one of them implying that the church should be neutral in political conflicts, while the second opts for the poor, claiming that the church should support the underprivileged part in a conflict. In this relation it is also motivated to deal with tools of social analysis and the issue of violence and state authority.

The study will account for an empirically existing debate, clarifying the theological structure used by the two main parties in the controversy and discuss them. Needless to say, there is a far more complex spectrum of positions in the actual discussion but it could be argued that the two analyzed positions are of special significance in two respects. First, they represent two clearly divergent and theologically elaborated positions which are of interest in a wider context, having significant parallels in many other parts of the world. Second, both positions are related to different political options of importance.

The two positions will be characterized as liberation theology and theology in defence of status quo. The former title is used by the advocates of this position themselves. The latter camp has no such generally accepted name. The title proposed here is chosen with reference to the fact that the South African state and its representation in Namibia obviously is the most powerful institution in support of this theological approach, even though it also counts church leaders and academical theologians among its protagonists.

\section{THEOLOGY IN DEFENCE OF STATUS QUO}

In this context I have to be brief when illustrating Namibian State Theology. ${ }^{2}$ However, two characteristic arguments should be highlighted as representative expressions of a theology in defence of status quo. The first is the response of the German Evangelical Lutheran Church (DELK) in Namibia to the Open Letter of the Heads of the African Lutheran Churches in Namibia to Prime Minister Vorster in 1973. In 
this response the Open Letter is refuted as a "purely political action", which "obviously oversteps the bounds of the Church's competence". 3

In fact, the separation between theology and questions of structural change has been emphasized repeatedly in this strand of thinking. In 1973, K Kirschnereit - the then Landespropst of DELK - squarely rejected the position of black Lutherans who saw the demand for a radical change in the power structure as part of the prophetic responsibility of the church.

In order to fulfil our Christian responsibility in a multiracial country, we have to subject to the recognized principles (i.e. constitution) of the country. Any faction which has as its aim the overthrowing of this constitution must be banned. A church which pursues these goals must take to the catacombs. ${ }^{4}$

In a church statement, the function of the "must" in the final sentence of the quotation is confusing, raising questions as: Does the "must" suggest that it is deemed legitimate for the state to persecute such a church? When a church is forced "to the catacombs" should the blame be placed on the church, not on the state? Is it per se illegitimate for the church to choose a way which is persecuted by the state?

Actually, there is a remarkable similarity between the pronouncements of DELK and of the South African govemment in the way of separating the two spheres of competence-the church and the state-even though, naturally enough, this distinction is most clearly elaborated by the professional theologians. Consequently, governmental leaders have frequently admonished Christian critiques of the apartheid system "not to mix religion and politics". One example is the discussion between ELOK and Prime Minister Vorster in 1973. When the Lutheran church leaders met the Prime Minister, Bishop Aulala from ELOK read some "Introductory remarks". One of them was as follows:

The conscience of the church compels her to reject a policy that encourages whites to place obstacles into her path and that prevents the church from functioning properly. 5

Mr Vorster reacted strongly against this principle, according to the official protocol, asserting

that the govemment does not want to have anything to do with the church if it is going to get mixed up in political matters. He adds that every kind of cooperation 
can be expected from him as a good Christian as long as the church sticks to her duty, which is preaching the Gospel. But if the church, to the contrary, understands her chief task to be getting involved in politics, then the cooperation is likely to suffer as a result. ${ }^{6}$

Anti-communism is a second important feature in the anti-liberationist theology. It presents the Namibian liberation movement as part of a communist "total onslaught" on Western, Christian civilization. Hence, it is argued, Christians are obliged to fight against it since it is said to represent an anti-Christian threat.

The reader may wonder how the obvious anti-communist partiality against the liberation movement may be reconciled with the alleged neutrality in political matters advocated by the protagonists of dualist theology. Yet, both lines of thought are indeed central in status quo theology. Its answer to the critical question seems to be that the combat of the liberation movements - allegedly representing a godless, antiChristian communism - is a spiritual task. Churches involved in anticommunist crusades are, according to this line of thought, not mixing religion and politics.

At a press briefing in Windhoek on 5 February 1981, a senior South African commander of the South West Africa Territory Forces (SWATF), General Charles Lloyd, said:

We cannot win this war through military means. We could actually destroy our military enemy. But that does not mean that we will destroy our political enemy SWAPO, which is in the minds of the Namibian people. As you know bullets kill bodies and not the minds. So we can destroy our military enemy, but that is not to say that we have destroyed the ideology of SWAPO. I would not say that we will solve the Namibian problem in a military way. That cannot be done, as I see it. What you really need for counter-insurgency is a good government. ${ }^{7}$

As a consequence of this strategy to maintain order and control in Namibia, the Dutch Reformed Church together with other conservative churches have formed the Namibian Churches Union. It is reported that sects such as Frontline Fellowship, Ichtus, American Pentecostals, as well as cultural-religious groups as Etango (Ovambo), Ezueve (Kavango), Ejuva (in the East) and Nambweza (Caprivi) organize religious meetings where they propagate anti-communist studies. 8 
It is against this kind of Namibian State Theology that conscientious Namibian Church leaders object and develop instead a Black Theology of Liberation. ${ }^{9}$ Zephania Kameeta is the most articulate Lutheran representative for this holistic theological alternative. ${ }^{10}$

\section{A BLACK THEOLOGY OF LIBERATION: KAMEETA'S EMPHASES}

To start with the holistic approach, in Kameeta's theology the ideology of the NSS, as we call it here, is confronted with the prophetic tradition of Christianity. Sin cannot be confined to individuals only, but is also a destructive reality within structures and systems, he asserts. This position is expanded in relation to a statement from a conference of the Federation of Evangelical Lutheran Churches in Southern Africa (FELCSA) in 1975, where it is maintained that a political system can be accepted as valid only insofar as it does not obstruct the will and purpose of God.

We affirm that a political system can be accepted as valid only insofar as it does not obstruct the will and purpose of God. We affirm that the political system in force in South Africa, with its discrimination against some sectors of the population, its acceptance of the break-up of many families, its concentration of power in the hands of one race only, and the limitations it imposes on freedom, cannot be reconciled with the gospel of the grace of God in Jesus Christ. . .

We are aware that... the righteousness God has given to us becomes the criterion of our personal and social relationships. We are also aware that those who accept racial divisions as guiding principles in the life and organization of our churches, and those who countenance the deprivation of human rights, dignity and worth of people created in the image of God, exclude themselves from the fellowship of Christian believers. ${ }^{11}$

Here Christian faith in God is interpreted as related to all dimensions of reality and therefore incompatible with a distinction of spheres where political and economic structures are seen as sacrosanct. Instead, it is maintained that all political systems must be measured with the standards of the will of God. The existing system in South Africa does not meet this requirement, Kameeta suggests, in agreement with many church resolutions on apartheid as heresy.

In marked contrast to a spiritualizing theology, Kameeta maintains 
that a person who really has tasted the liberation in Christ does not withdraw into a "spiritual" sphere but he goes into the world and sacrifices himself for the liberation of his neighbour. In this perspective the basic choice can be described as a choice between justice and injustice. Therefore Kameeta rejects both "the thinking in two spheres", to use Bonhoeffer's terminology, and the criticism of a prophetical message as an interference in politics.

In other words, a political commitment which in the status quo theology is censured as pastors "meddling into politics", is here defended as "a prophetic voice". This line of thought suggests that a preacher who avoids politically or economically controversial issues will betray the prophetic dimension of preaching. Moreover, the NSS ideology of "law and order" is here understood as an ideological justification of an unjust system. In other words, this ideology is obviously seen as a smoke-screen to conceal exploitation and oppression. ${ }^{12}$

In line with this understanding of the prophetic tradition, Kameeta relates the political and socioeconomic issues with spiritual life. The struggle against injustice is seen as an essential dimension of a "confessing church" in Namibia, implying that a church which stands aloof of this struggle betrays the confession in God.

The emphasis on prophetic commitment is seen also in the perspective "from below". The claim of neutrality, which is essential in dualist theology, is refuted in this theology and it is even suggested that an alleged neutrality can serve to increase the injustice. Neutrality, Kameeta maintains emphatically, is incompatible with the prophetic vocation of the Church.

A prophetic voice can never be neutral in a situation of conflict. Neutrality has in fact no place in the vocabulary of God. There is and will be no such time where this voice can be tamed into neutrality. How can the messenger of God be neutral, while the God who is sending him or her is never neutral. ${ }^{13}$

When Kameeta opts for "a black theology of liberation", blackness does not signify a certain colour of skin but "a condition of wretchedness in which the oppressed live", "the black reality in conflict with the status quo". ${ }^{14}$ In other words, "black" here should not be understood as an ethnic term but rather in agreement with the Hebrew concept of the "poor". 15 
Similar views may be found in many church resolutions and texts by other Namibian theologians. In a presentation about ELC (SWA) the polarization between a holistic and a spiritualizing theology is clearly stated.

To many the church has abandoned the pastoral domain to enter the political arena. To others this was an answer to their persistent call that the church should not only care for the soul of man but also for his physical being as well. ${ }^{16}$

In this conflict the African Lutheran Church has opted for the latter position which, in sociological terms, is characterized as an option for the poor. In other words, the conflict is not interpreted in terms of an East-West conflict but rather as a North-South confrontation, i.e. between privileged and underprivileged.

The church remained vocal in identifying itself with the downtrodden masses yearning for liberation and also to be as the conscience of the nation. ${ }^{17}$

Needless to say, the theological perspective accounted for here may be found in many other parts of the so-called Third World as well. Therefore, it may be useful to interpret them within the wider context of black theology in southern African and liberation theology in Africa, Asia and Latin America.

\section{LIBERATION THEOLOGY AND BLACK THEOLOGY}

In our account of liberation theology, the reports from The Ecumenical Association of Third World Theologians (EATWOT) will serve as a guiding principle, since this organization is an important forum comprising some of the most noted liberation theologians from Africa, Asia and Latin America.

With reference to the EATWOT reports, liberation theology can be defined as a holistic theology opting for the poor as "interlocutors". Hence a theology has to meet two criteria to be classified within this approach, as we understand it: (1) To choose the poor and underprivileged party as the "interlocutors" of theology. (2) To opt for a holistic theology, seeing all spheres of society as related to the obedience of God. 
In this limited space it is only possible to give a brief sketch of this approach, leaving out the new way of "doing theology", i.e. a methodology which unites commitment and reflection, seeing theology as reflection on experience. At the founding meeting of EATWOT, Gustavo Gutiérrez, nestor of liberation theology, referred to interlocutors as partners who qualify the conditions for the discourse. ${ }^{18}$

In the apartheid empire, the option for the oppressed as interlocutors will, for obvious reasons, imply a theology from the black perspective. In other words, black theology can be seen as a branch of liberation theology. Accordingly, Allan Boesak defines black theology within the context of liberation theology as follows:

Black Theology is theological reflection of black Christians on the situation in which they live and on their struggle for liberation. Blacks ask: what does it mean to believe in Jesus Christ when one is black and living in a world controlled by white racists? And what if these racists call themselves Christians also? ${ }^{19}$

The holistic approach entails that faith in God and the quest for his justice is explicitly related to all dimensions of human life. The universal horizon is highlighted already in the name of a theology of liberation. This title has caused some confusion among followers of a compartmentalized thinking, used to separate politics, economy, culture, religion in distinct spheres. Theology, in this perspective, belongs to the compartment of religion, naturally, and eo ipso not to the compartment of politics or economy. "Liberation" on the other hand is, in a compartmentalized approach, generally a word related to the political sphere. Liberation theology has therefore often been interpreted as a theology which, for one reason or another, has lost its religious concern and instead is moving its focus of interest from the religious sphere to the political one. But who will care for the compartment of religion if it is deserted even by the theologians, the critics of liberation theology seem to think.

A careful study of this multifaceted movement of theology reveals, however, that all liberationists, in spite of many differences, share in common (1) a rejection of a compartmentalized world-view and (2) an affirmation that faith in God must be related to all dimensions of life, including economy and politics. In short, liberation theology wants to break down the walls which separate religious life from other dimensions of reality. This holistic approach was forcefully stressed already in 
Gustavo Gutiérrez' Teología de la liberacion, which could be called a classic of this movement. Here Gutiérrez distinguishes between three reciprocally interpenetrating levels of meaning of the term "liberation".

* In the first place, liberation expresses the aspiration of oppressed peoples and social classes, emphasizing the conflictual aspect of the economic, social, and political process which puts them at odds with wealthy nations and oppressive classes.

" "At a deeper level", liberation is related to the unfolding of all of human dimensions in history, the search for "a new man and a qualitatively different society".

* Finally, the word liberation leads to the Biblical sources where "Christ is presented as the one who brings us liberation". ${ }^{20}$

Gutiérrez is eager to emphasize, however, that these three levels of meaning should not be seen as a matter of three parallel or chronologically successive processes. They form, according to him, "a single, complex process, which finds its deepest sense and its full realization in the saving work of Christ". ${ }^{21}$ The approach of GutiCrrez has here been discussed at some length, since a similar holistic perspective shapes all varieties of liberation theology.

Liberation theology, far from reducing theology to the sphere of politics, wants to relate all dimensions of human life to the faith in God and the quest for his justice. Hence, it is characterized by a stem refusal of the dualist position described above. The idea of autonomous laws governing politics and economy, unrelated to the Biblical quest for justice, is rejected as an idolization of state and capital. In this regard, Kameeta is in full agreement with the Peruvian pioneer of Liberation Theology.

\section{A THEOLOGY FROM THE UNDERSIDE OF HISTORY}

The holistic understanding of God in liberation theology is based upon a new way of "doing theology", a new methodology. One important aspect of this new approach is expressed in the phrases "theology from the underside of history" and "the hermeneutic privilege of the poor". Both expressions evolve from the differences between two distinctive perspectives: that of the rich "from above" and that of the poor "from 
below". The new methodological approach naturally signifies that one has opted for the latter vantage point, the perspective of the poor from the underside of history.

Not surprisingly, this conflictual approach has stirred controversy in many quarters. Even though it is impossible to cover this complex debate in this study, we will deal with one aspect of liberation theology that is often overlooked; its call to metanoia (conversion), the fundamental crossroad in Christian faith. In this school of thought, the option for God (as opposed to the option for an idol) is related to the option for the poor (as opposed to solidarity with the rich). The true God, it is asserted, is only found within a praxis of solidarity with the oppressed and poor.

We are witnessing in our time the same choice which confronted biblical peoples between allegiance to false gods and fidelity to the true God (Ex. 32:1-10; Ps. 78:52-63; Ezek. 6:3-7). In contrast to the gods of the global system, the true God is not revealed among those on the throne of power and affluence, but among the least valued according to the reigning canons of respectability - the victims, the voiceless, the powerless, those on the underside of history (Matt. 25). ${ }^{22}$

In other words, the commitment to the poor in this approach is both a sociopolitical and a theological act. Justice is seen both as a political principle and as the way of knowledge of God (Jer. 22:13-16). The true God is the source of justice while idolatry always causes injustice, claims Pablo Richard in an important essay on Biblical Theology of Confrontation with Idols:

The practice of justice and correct thinking about the Lord go together. When practicing injustice, one necessarily thinks idolatrously about the Lord. ${ }^{23}$

When speaking of a Liberation Theology, which emerges "from the underside of history" it is important to note that the basis and style of this theology is different from that of traditional academic theology. There is a characteristic link to popular spirituality of combat.

In the case of Namibia it is, thus, inevitable to refer to the famous Nama leader Hendrik Witbooi, the Lutheran convert who was inspired by the Old Testament and Luther's doctrine of God's twofold governance in his political commitment. Significantly, Witbooi used, inter alia, theological arguments when rejecting the claims of the German colonialists. Writing to the German governor, he states, 
The Lord God has placed various kingdoms in this world, thus I know and believe that it is neither a sin nor a crime that I should wish to remain independent chief of my own country and people... But you talk of power and justice, and by your own admission you deal with me because you are powerful in weapons and the comforts of civilization, and I must agree that you are truly powerful, and that I am as nothing in comparison to you. ${ }^{24}$

Significantly, Dr. B Schwam, a visitor to Witbooi's residence in Hornkranz in 1888, complained about what here is called a holistic spirituality, but in his report was described as a confusion of religion and politics.

It is not difficult to find similar expressions of a holistic spirituality also in later times, e.g. Chief Hosea Kutako's oft-quoted prayer at an important juncture of the struggle for freedom: "You are the great God of the earth and the heavens... Give us the courage to struggle in that way for what is right." Similarly, Hermann Toivo ya Toivo in his address to the court referred to the frequent appeal in freedom document "to the Almighty to guide us in our struggle for freedom". ${ }^{25}$

As already noted, this emerging Black Theology of Liberation in Namibia deliberately counteracts a distinct State Theology with a simplistic anti-communist bias. We have, thus, to add a dimension to our analysis, i.e. to illustrate the attitude to and use of Marxist tools of analysis in this Liberation Theology.

\section{THE USE OF MARXISM IN LIBERATION THEOLOGY}

Discussing the use of Marxism in liberation theology, it may be helpful first to give a general view and then to deal with the specific situation in Southern Africa.

Why do theologians who are participating in liberation movements often recur to Marxist social analysis? In answering this question, parallels with anti-communism may lead us astray. In anti-communist theology there is a totalitarian rejection of any use of Marxism, as we have seen. In analogy, some students seem to think that liberation theology has a similar totalitarian approach, but in favour of Marxism.

However, this is not the case. Leading fora of liberation theology, e.g. EATWOT, have clearly asserted that a comprehensive analysis of contemporary reality cannot build upon one set of theories only. Hence 
Marxism, feminism, pre-capitalist cultures etc. inform the analysis of the organization. These different sets of ideas are used in a complementary fashion.

Those who know liberation theology from the inside can assert that the discussion on how to combine these modes of analysis is an important aspect of reflection. In fact, many First World feminists want to give priority to feminism over Marxism, even though they accept also the latter theory as a contribution. ${ }^{26}$ In short, the experience from the liberation struggle is the distinctive criterion in the choice between different modes of analysis.

Even though this criterion surely involves many thorny problems which cannot be discussed in this limited space, it is clear that the usefulness of Marxism is not seen as an a priori truth but is assessed in relation to praxis. The Argentinian José Miguez Bonino has summarized this experience as follows:

It is my thesis that, as Christians, confronted by the inhuman conditions of existence prevailing in the continent, they have tried to make their Christian faith historically relevant, they have been increasingly compelled to seek an analysis and historical programme for their Christian obedience. At this point, the dynamics of the historical process, both in its objective conditions and its theoretical development, have led them, through the failure of several remedial and reformist alternatives, to discover the unsubstitutable relevance of Marxism. ${ }^{27}$

In short, the use of Marxism can, according to liberation theology, only be legitimated by reference to praxis, i. e. experience from the liberation struggle. The critical use of Marxism in liberation theology differs fundamentally from the totalitarian rejection of this mode of analysis in anticommunism. Liberation theology does not imply that Marxist analysis always should be invoked but it does imply that it is perfectly legitimate also for a Christian to refer to such an analysis when it clarifies his or her experience in the liberation struggle.

If it generally is a serious distortion of truth to describe liberation theologians as communists, this is all the more true of southern Africa. In Latin America, theologians have opted for what is called a strategic alliance between Christianity and Marxism, implying independence but mutual cooperation. In South Africa and Namibia, contrary to the government claims, this has not occurred, although there has been an extensive criticism of the ethos and structure of capitalism. An analysis 
of the economic system has to some extent been used to substantiate the need of a structural - as opposed to reformist - change. This analysis has also helped to explain that it would not suffice to replace white capitalists with black ones. Similarly, such an analysis seems to have informed the account of South African dominance in Namibia and the possibility of changing the economic laws. In this social analysis there is obviously some influence from the Marxist tradition, e.g. in the use of concepts as capitalism or class, in the discussion on the relationship between racial and economic oppression and - most important - in the assertion of the transient character of this economic system. ${ }^{28}$ Even though it is quite possible to find evidence of Marxist influence in black theology, the same is true of much contemporary social analysis also of a bourgeois strand. To use these traces as argument for the gross charge that black theology is part of an alleged communist "total onslaught" is clearly unwarranted, not to use a stronger word.

\section{VIOLENCE AND CONFLICT}

The question of violence and conflict is a specific issue at dispute. Here there is a misunderstanding similar to the above-mentioned confusion on Marxism and liberation theology. In the ideology of NSS any use of revolutionary violence is prohibited. When liberation theology rejects this position, it is often assumed that it advocates armed struggle as the only means of liberation.

In fact, there are different positions on violence and non-violence within this strand of theology. In common for the different positions is, however, the situation that the choice between justice and injustice - not between violence and non-violence - is seen as the main issue.

Therefore, also those who subscribe to non-violent methods will acknowledge a fundamental solidarity with those who use violent means in the struggle for achieving the goal of justice. On the other hand, violence is never advocated in liberation theology as an end in itself but only as ultima ratio, a means which may be used in such situations where no other way to combat oppression is found open. Hence, in liberation theology the choice between violence and nonviolence is not a matter of abstract principles but a question of social reality and actual possibilities of change. 
Actually, such a position is not uncommon. In a well-known statement in court, Toivo ya Toivo argued in a similar way, addressing those who accept the goal of independence but rejects the means of military struggle. "There are some who will say that they are sympathetic with our aims, but that they condemn violence." 29 In his comment on this position, Toivo does not neglect the problems of violence: "I would answer that I am not by nature a man of violence and I believe that violence is a sin against God and my neighbour." 30 And he adds: "SWAPO itself was a non-violent organization from the outset." ${ }^{31}$ How could he then support an armed struggle for freedom, some may wonder. The answer can only be understood within the framework of the experience of the combat for liberation. The choice of military means was forced upon the organization by the intransigence of the South African government, asserts Toivo:

The South African government is not truly interested in whether the opposition is violent or nonviolent. It does not wish to hear any opposition to apartheid. Since 1963 SWAPO meetings have been banned ... We have found ourselves voteless in our own country and deprived of the right to meet and state our own political opinions.

Is it surprising that in such times my people have taken up arms? Violence is truly fearsome, but who would not defend their property and themselves against a robber? And we believe that South Africa has robbed us of our country. I have spent my life working in SWAPO, which is an ordinary political party like any other. Suddenly we in SWAPO found that a war situation had arisen and that our colleagues and South Africa were facing each other in the field of battle. ${ }^{32}$

In this view, a liberation war can be characterized as a war of defence, whereby the oppressed defend themselves against the aggression of oppressors. Such an approach which is not infrequent among theologians of liberation implies that the first act of violence was not the commencement of the liberation war but the colonial conquest, the economic exploitation and the racist oppression, e.g. in Namibia. The armed struggle for liberation is here seen as a means of self-defence to end the primal violence of an oppressive system. In fact, his line of thought corresponds with a classical Christian position that violence may be used for the purpose of defence but not for attack.

However, the NSS position that violence may be used to defend status quo but not for crushing oppression seems often to be considered as the traditional one in the churches. This may be true when it comes 
to the two last centuries but not in a longer perspective. Thomas Aquino, the great Catholic theologian, just to mention one name as example, asserted the right of the people to assassinate a tyrant for the sake of restoring justice and peace. In similar fashion many theologians have chosen a way different from the idolization of the state in the NSS ideology. Admittedly, Luther claims that the main rule is that Christians should obey the government and not rebel. He maintains, however, that God often sends what he calls heroic men (viri heroici) who have God's mandate to break such a rule for the sake of justice. These "heroic men" can in Luther's view be Christians or non-Christians. As examples he mentions Moses and Alexander the Great. Even though the approach of viri heroici is surely not unproblematic, it may remind us that also in earlier times Christians have regarded justice as more fundamental than the concept of "law and order" proposed by those in power. In this perspective one should ask for a more careful reading of Romans 13 with its famous teaching on government. Paul here describes the government as "God's servant", using leitourgos both to mean liturgical function in the worship and serving the common good. The commands of such a government are said to be in accordance with the will of God, supporting good acts and punishing evil.

The oft-neglected question then is this: Does Paul's word apply to any person who seizes power over a territory? Will such a person deserve complete obedience even if he acts against Paul's description, disregarding the will of God, punishing those who choose justice and supporting the evil-doers? Can an Adolf Hitler, or a Josef Stalin, or a P. W. Botha legitimately be called God's liturgs? If one takes the Biblical teaching on justice seriously, I suggest we have to answer in the negative.

\section{NOTES}

1. A more extended version of this paper was discussed at the seminar and will be published separately.

2. To the term "State Theology", cf. The Kairos Document, Challenge to the Church. A Theological Comment on the Political Crisis in South Africa. Revised second edition. Skotaville Publishers: Braamfontein, 1986, $3 \mathrm{f}$.

3. Quoted from K. H. Hertz, Two Kingdoms and one world. A Sourcebook in Christian Social Ethics. Minneapolis 1976, p. 264. Some years later DELK somehow modified its position. See ibid., $265 \mathrm{f}$. 
4. Quoted from op.cit. 153. Italics added.

5. Excerpts from the Protocol of the Conversation between Prime Minister Vorster and Representatives of the United Evangelical Lutheran Church in Southwest Africa (VELKSWA) on April 30, 1973. Quoted from Hertz (1976) p. $257 \mathrm{f}$.

6. Ibid.

7. Quoted from WHAM "Winning Hearts and Minds", (no printing year, published by TEP, Cape Town), 14.

8. Ibid., 15.

9. On this whole issue, see further A. Nolan.

10. Z. Kameeta, Why, O Lord? Psalms and sermons from Namibia. The Risk Book Series No. 28 (World Council of Churches, Geneva, 1986).

11. FELCSA Conference, 11-13 Feb. 1975. Quoted from op.cit. 13f.

12. Cf "Towards a Confessing Church in Southern Africa" in ibid. 52: "The messengers of this world said that they were protecting "law and order", but the prophetic voice said that this was a protection of injustice and brutal oppression. ... Many Christians ... even ... preach that the adaptation to the structures of this world, is the divine will of God."

13. Z. Kameeta, Why, O Lord?, 53.

14. Ibid., 11.

15. See Frostin, P., Liberation theology in Tanzania and South Africa: A First World Interpretation. Lund: Lund University Press, 1988, 87.

16. The Evangelical Lutheran Church in SWA (ELC) Rheinish Mission church (Pamphlet without printing year).

17. Ibid.

18. See Frostin, P., (1988), 6-7.

19. Allan Boesak, Farewell to Innocence. A Socio-Ethical Study on Black Theology and Black Power. Orbis Books: Maryknoll, New York, 1977, lf.

20. Gustavo Gutiérrez, Theology of liberation. SCM Press Ltd, London 1974, 36 f. Italics removed.

21. Ibid., 37.

22. Virginia Fabella \& Sergio Torres, Doing Theology in a Divided World. Orbis Books: Maryknoll, New York 1985, 190.

23. In Pablo Richard et al. The Idols of Death and the God of Life, $\boldsymbol{A}$ Theology. Orbis Books: Maryknoll, New York 1983. This anthology, produced by a Latin American team, gives a comprehensive account of the analysis of idolatry in Latin American liberation theology.

24. Quoted in Bley 1970, 32. Speaking about "the theological motivation behind Hendrik Witbooi's freedom struggle" J Lukas de Vries claims: "His deep religious understanding often revealed a touch of mysticism ... The Freedom of God's nation, as this was revealed in the Old Testament, was for him a living example of the struggle for freedom in South West Africa." Mission and Colonialism in Namibia. Johannesburg, 1978. Discussing de Vries' intepretation, Ntongela Masilela suggests a more nuanced analysis: "Though the theological factor was of crucial importance in determining the personality and the political activities of Hendrik Witbooi", de Vries is wrong in giving it "the sole deter- 
mining importance". Project: A Research Proposal for the Study of Germany in Namibia (South West Africa): Nationalism, Colonialism and Religion, 1840-1915 (Elements of a Biographical Study of Chief Hendrik Witbooi, 1838-1905) (mimeographed), 6.

25. Ibid.

26. Namibia. The Strength of the Powerless. A Dossier by Heinz Hunke on behalf of IDOC International. Rome 1980, 48. This dynamic discussion can be found in the reports from all EATWOT conferences. Yet, it may have been most poignant at the conference in Geneva in 1983. See further Virginia Fabella \& Sergio Torres (eds.), Doing Theology in a Divided World.

27. J. Miguez Bonino, Christians and Marxists, The Mutual Challenge to Revolution. London 1976, 19.

28. Contrary to popular opinion, the core of Marx' opus magnum-The Capital - is not to prophecy about a socialist future but to argue for the analysis of capitalism as a historically transient system. In fact, Marx differs from bourgeois economy not so much in the exposition of the content of the economic laws (where he as a matter of fact basically agrees with Adam Smith and David Ricardo) as in the definition of their status: Are the economic laws eternal and unchangeable or historical, i.e. can they be changed and replaced in a new economic rationality beyond capitalism? Hence it is unequivocally stated in the author's preface to this book: "It is the ultimate aim of this work to lay bare the economic law of motion of modem society." Lewis S. Feuer (ed.), Karl Marx and Friedrich Engels, Basic Writings on Politics and Philosophy. With an Introduction by Lewis S. Feuer (New York: Collins, the Fontana Library, 1969), 177.

29. Toivo ya Toivo, op cit., 46.

30. Ibid.

31. Ibid.

32. Ibid. 



\section{Lessons from Zimbabwe}





\section{Insights from the Second Chimurenga \\ Patrick Mutume}

The liberation struggle is a process and is not an event. During white minority rule it was believed that society was unjust and needed to be corrected. The churches in Zimbabwe were in control of the youth through their schools. They had a golden opportunity to influence their thinking. Among the champions of freedom was the Methodist bishop Dodge. Most people tend to forget him when they talk about the history of Zimbabwe. And there comes also bishop Lamont and bishop Skelton who is Anglican, both of whom consistently opposed against the regime, the discrimination and the unjust society.

These men were talking about things that the general public did not really understand. For instance, bishop Lamont wrote a pastoral letter entitled The purchased people. In this document he enlisted what a just war is all about, when people could take up arms. That in itself was very prophetic. Because, the nationalist reading this, when they hit against the wall, they saw that their option was only to take up arms and free themselves. Attempts were made to see the internal leaders ${ }^{1}$ without success. Even bishop Muzorewa, when he took power he did not grant the Church, or the Head of Churches, an audience to listen to them.

\section{INSIGHTS FROM THE WAR}

The Bishops' Conference became more and more critical and then followed up this stand with pastoral letters. The commission for justice and peace published a lot of documents during the actual struggle, in which they even put pictures of people who had been mutilated and homes that had been burnt, and people who had been tortured. The arrest of many missionaries began. And a lot of missionaries were tortured and put to trial. Some of them had to serve full term. After 
n . time bishop Lamont was arrested and sentenced to ten years of imprisonment He appealed, five years were suspended and five became. effective. After that he was deported.

At his trial he did not try to defend himself as he was innocent. He was saying that the law of reporting guerillas was not possible to keep. Because if you did not report, the government will sentence you to death. If you did report the freedom fighters will sentence you to death. In each case you are dead.

The church wanted to prove that this law could not be kept-you can only keep it and die. So with that it became not a case of becoming loyal to the state but a case of trying to prove the state and its laws unjust. The regime would execute many people for not reporting the presence of "terrorists". This became a big concern for the church. Because many people got killed. And until anybody was arrested it was no point defending oneself. All the priests and missionaries who were arrested under this law were not saying that we did not see the terrorists. They were only saying that this law must go.

The freedom fighters needed supplies. It was the man of the church who had the means for going to town. He had the transport, he could be trusted. There was a lot of cooperation between the freedom fighters, local people and the church. That is how the churches got involved, but I do not want to give you the impression that every church person had a similar mentality.

I remember a priest who went to the barber shop to get his hair cut. He used to talk to the man who used to cut his hair and started talking about these things. And within two hours the police went after him. The police missed him by half an hour. They came to the airport when the priest just had boarded the plane, which was already on the runway. The police could not arrest him. This was in 1979 just in the end of the struggle.

The church was not a friend of the regime. It was always a suspect. Because it was found to be existing in areas in which there were freedom fighters it was taken for granted that they must be supporting them.

The priests of the outstations were consulted by the freedom fighters to assess the feeling of the people. The people would be truthful to the priest and tell him how they felt about the war. And the people were also aware of this so they also consulted him on how the situation were 
and how the war was going. And they would also assess from that point of view. They criticised together with the people.

Churchmen in town had a completely different mentality because they were not involved. Even in the catholic church if you came into town, you did not discuss what was happening in the bush, because they just did not understand. The churchmen in town, thus, differed from the people in the rural areas. The source of information for the men in town were the radio and papers, that is tools of the propaganda machine. He relied on information from the official source.

\section{INVOLVED PASTORAL LETTERS}

The bishops pursued their protests by writing pastoral letters. In one pastoral letter we tried to show that the people in fact were not different, that they are one in God and therefore they should not be segregated.

The Commission of Peace and Justice which was an arm of the bishops' conference, did also publish a lot of material. One of those was Land Tenure Act which is spelling out the division and unjust distribution of land. And the other was War in Rhodesia. All this was spelling out the anguish of the people, the unjust structures. The reason why there was war. It had to be explained.

I remember during that time, that if you walked into a cathedral on Sunday, people would pick up their handbags and walk out. If you were a bishop you had to get used to that. You could never be sure that you were going to have a congregation. Especially if it was not a mixed congregation you would run the risk of standing there alone. There were also organisations supporting the government which were particularly there for propaganda and attacks on the church.

As time went on the bishops felt that they were not talking for themselves, they were talking for the people who were voiceless.

The freedom fighters were not treated like saints by the church. The bishops attacked them if they were wrong. For the way they saw the freedom fighters was that if they made mistakes in their tactics, it meant prolonging the war, and therefore a lot of lives would be lost.

It became apparent that the bishops could not just stay at home and fight their battles there. It meant that the bishops had to go and meet 
the leaders of the struggle, argue with them and talk about the directions of the war and the morality of the war. A lot of things were being discussed at the time with both leaders, Nkomo and Mugabe.

One of the issues discussed was the fact that a lot of men had withdrawn from the actual battlefield. They had lost direction. They had become very comfortable and they would not fight. They would just get food from the people and run away from the security forces. And this would not please the bishops at all, because it meant that the war was going to continue for a very long time.

\section{AT LIBERATION}

At liberation the big surprise of everyone was that the archbishop of Harare at the independence celebrations was invited to start with a prayer, because the propaganda had it that if Mugabe took over he was going to persecute the church. You can imagine, the people had been going through thirty years of propaganda and they had been told all this time that the church would have no place in the new administration. And suddenly they find a bishop in the middle of it all, saying a prayer. This was a shock to a lot of people. Also the speech which the then Prime Minister Mugabe held on reconciliation shocked many.

Even today there are people who do not believe it is true that you can live together black and white, side by side. The present administration has been able to make four armies to become one army. This in itself is a big achievement, but most of this is never acknowledged.

The bishops opening the proceedings at the independence celebrations became tradition in Zimbabwe, because on Heroes' day or on any other big event, the proceedings are always started with a prayer. The Heads of Churches are always reminded to send in the names of the heads of churches and of the one who is going to say the prayer and whose name will be in the programme. But as in every country not everything is rosy. There are problems. But I think they are of lesser nature than otherwise would have been the case.

When president Mugabe was interviewed on this particular issue of church and state relations, he said:

... we are partners in the development of our country. The person whom we deal with as politicians is the same one who is a christian as well. It means we are 
dealing with a same person. And politicians and the Church are dealing with the same man. Therefore we are partners. We are partners also in the development of the country. And therefore let us join hands to consolidate our hard won independence.

That from his address to the Commission of Justice and Peace in Gweru 1982.

\section{THE CHURCH'S RESPONSE}

The Catholic Bishops' Conference immediately after independence wrote a pastoral letter called "Our way forward". In this document we spelled out what route we should follow, in light of the reconciliation policies that had been enunciated by the president. It was followed by a crucial document that raised a lot of conflict between the state and the church for a while during the problems in Matabeleland. This was the document which we called "Reconciliation is still possible", in which the bishops called for a committee of inquiry about the things happening in Matabeleland. The government did institute a commission of inquiry and the government found out what was happening there, and the situation improved.

When the question of Socialism became an issue in Zimbabwe, the bishops again wrote a pastoral letter to say exactly what they thought about Socialism. In this document, "Socialism and the Gospel of Christ", the bishops spelled out what they felt socialism should be and what it should not be. This document, in fact, the government used a lot.

At our first general election, people felt that it might be punctured with violence. The bishops again had to write a pastoral letter, this time called "Peace, unity and justice".

Lately because there was a discussion on the question of education, they wrote another one, on our call to educate, to explain the role of the Church vis-8-vis education and what role it plays.

Sometimes pastoral letters are written before the questions are becoming real burning issues. For instance, the one on "Socialism and the Gospel of Christ" did not make much sense when it was published. But as time went on people had to read that document. We try to keep abreast to the situation in Zimbabwe as much as possible. 


\section{LESSONS FOR SOUTH AFRICA}

One of the lessons to draw is that unless the Church in South Africa identifies itself with the people, it will be irrelevant when independence comes. It has taken the churches in Angola and Mozambique at least ten years to be able to become involved in a dialogue with their governments.

We did not have as many whites in Zimbabwe as in South Africa and we did not have so many white parishes as there are in South Africa. This also gives problems. If we had problems with the few parishes that we had in Zimbabwe, definitely there are more problems in South Africa vis-à-vis the church. Because the change is not only physical, it is also a psychological change and people need orientation. In a land where you are bombarded sometimes people do not see the wood for the trees.

The Zimbabwean Catholic Bishops' Conference thus also has its battles with its counterparts there. Some of the things we said to them at the time were not palatable to them. But after the 80s they were prepared to listen to us because they felt we had done something. But before that it was difficult to tell them to change the course they were following. But they have taken initiatives, through learning from other countries that they had not expected to identify with.

This, I think, concerns the relationship of the church to ANC as well. ANC has never as yet run a government, and do not expect them to be so experienced as if they have been running a government for many years. That is very unrealistic, and that is to expect too much of an organisation. Therefore, what we are saying now when we talk about the church and the state is that the church must be true to itself. Must be prophetic before and after independence. There is no way that after independence you are going to sit and relax, From what I have said it was still a struggle for the Church to find its way. It still has to find its way and it still has to reflect, to read the scriptures and reflect on them and see where the Holy Spirit is leading it to.

And therefore we demand action in all that we do. If there were a problem we would never just ask people to pray, we demand action as well. Praying, we always say, has to be combined with action. A prayer which do not produce action. I do not know what it is. A prayer shall be able to inspire you into action. 


\section{NOTES}

1. Those which were given prominent functions without real power by the Smith regime, while still not allowing majority rule and voting rights. (Editors' comment.) 


\section{Catholic Youth Mobilization in Zimbabwe}

Paul H. Gundani

The demographic situation in Zimbabwe is highly titled in favor of the youth (under 15 years of age) who, in the African sector alone, were estimated at about 50 per cent of the population in the 1982 census. But because of the society's concept of maturity and responsibility, the youth have never been seriously considered to take part in decisionmaking. This has been the same in the church. Fr. A. Bex corroborates this observation, noting that in the life of the church, for far too long the youth have been regarded as "children to be seen and not to be heard". 1

The aim of this study is to do justice to this population sector - that has always been considered minor and hence refused voice by the society and church - through an inquiry into the spirituality and theological perspectives of the Zimbabwe Young Christian Students (ZYCS) movement in terms of liberation theology.

\section{THE BACKGROUND AND RISE OF THE YOUNG CHRISTIAN STUDENTS MOVEMENT IN ZIMBABWE (1972-1979)}

From the Young Catholic Workers' movement to the Young Catholic Students' movement

The Young Christian Students' movement of Zimbabwe is a lay Christian movement. At its formation in 1972 it attracted a predominantly Roman Catholic membership from Roman Catholic mission secondary schools. However, since this was a time of crisis within the church schools in Zimbabwe due to the new Education Bill of 1971, a less confessional outlook in mission schools influenced the YCS movement to admit non-Roman Catholic Christians into its fold. The movement in its embryonic stage appealed to the Christian responsibility of each member, Catholic or non-Catholic, as baptized people. 
From the outset the movement felt that it was responsible "for its own options in accordance with the mission of the Church".' The Zimbabwe YCS movement is an offshoot of the Young Christian Workers' movement started by a Belgian priest, Fr. Joseph Cardijn. ${ }^{3}$ A Belgian diocesan priest, Fr. Cardijn with the enthusiastic approval of Pope Pius XI, officially launched the Young Christian Workers (YCW) at Brussels in 1927. "The YCW movement was based on the principle of action of 'fellow on fellow', i.e., workers should be the apostles of their fellow workers." Cardijn's slogan, "Among themselves, by themselves, for themselves" became the central tenet in the movement. ${ }^{4}$

The YCW movement advocated a method of study which was based on these principles: See, Judge and Act. This method became popularized as the "Review of Life" analysis. It aimed at religious, social and economic renewal and called on the participation of the entire mass of the working class. ${ }^{5}$

In 1930, three years after the formation of YCW, Cardijn's ideas and methods of analyzing society gave rise to a similar movement in schools under the name of Young Belgian Catholic Students. "The new student movement spread to France in 1930, and under leaders such as Louis Chauldron and Marc Scherer attracted considerable attention because it dared study such touchy problems as peace, war and the coming of a proletarian civilization."

By 1939 the Young Catholic Students' movement had spread to ten countries, including Spain, Switzerland, Britain and Canada. After World War II it gradually moved into the Third World. By the 1970s, when it was introduced to Zimbabwe, the movement was already active in about seventy countries. ${ }^{7}$

\section{The post World War II missionary movement and the Zimbabwean YCS}

The fact that the YCS and the YCW movements were both formed in the same diocese and in the same year, 1972, is significant. In a way, it shows the sense of cooperation and urgency in the religious personnel within the Gwelo diocese in the implementation of the Second Vatican Council's decrees. While it is true that the Zimbabwean YCS movement was influenced by the Vatican II's "Decree on the Church" that accorded the laity dignity and responsibility in the Church, it is important to note that the Vatican, before Vatican II, was influenced by the 
pedagogical principles of both the YCS and YCW movements.

In 1961, Pope John XXIII in his "Mater et Magistra" writes: "In reducing social principles and directives to practices, one usually goes through three stages; reviewing the actual situation, judging it in the light of these principles and directives, and deciding what can and what should be done to apply these traditional norms to the extent that the situation will permit. These three steps are usually expressed in three terms: observe, judge, act. ${ }^{18}$ It is interesting that the subsequent paragraph refers particularly to young people whom he calls upon to "reflect on this program and even more, as far as possible, follow it in practice, so that the doctrine they have learned will not be viewed merely as a set of abstract ideas but as something capable being translated into deeds."

This is apparently the first time for this method-appropriately called the Review of Life - i.e. See-Judge-Act — by the YCS and YCW to be articulated in official Vatican documents. However, it is not surprising for John XXIII to appropriate such terminology since before being elected pope, he (Roncalli) was an advocate of the radical worker-priest movement which was active in France and Belgium more than elsewhere. Roncalli should have gained a lot of exposure to not only the worker-priest movement but also to the desire to create a broad-based movement.

Many YCS/W groups were formed particularly in the eastern and western deaneries of Gwelo diocese. Schools like Mukaro, Gokomere, Berenja, Loreto, Chikwingwizha and Bondolfi Teacher's College became the centers of workshops and study weekends geared toward learning how to run YCS/W meetings and sessions, doing the Review of Life analysis and exploring the common problems at various schools and workplaces and mapping out the types of strategies and actions the movement could undertake. At such a stage the movement tended to stress pertinent and small but "liberating actions" rather than "charitable and paternalist actions". ${ }^{10}$ Traditional Christian actions like visiting the sick, holding prayer meetings, teaching catechism to the young, helping raise contributions for Lenten programs, etc., became the assumed actions. More involved actions based on a thorough analysis of the conditions obtaining, and judged against the Church's teaching. Scriptures and African traditional values were carried out.

As Angelika Laub said in an interview, "More sensitive issues questioning the harshness and authoritarianism at workplaces and schools, 
injustices committed by teachers, boardingmasters/mistresses and headmasters/mistresses against the students, and those committed against workers at missions, in mining, industry and commerce were tackled." " As the liberation was intensified in the late seventies, the actions and demands of the YCSN tended to be successful just as much as the general student demands in the rural areas were. This was necessitated by winds of change blowing across most of rural Zimbabwe as the Guerilla war was intensifying. However, due to the extended operations of the Rhodesian Army the YCS/W involvement was forced to operate in restricted localities. The situation went on until independence in 1980.

\section{Developments during the Liberation Struggle}

There are many ways in which the YCS/W in fact benefitted from the inhibitions that came with the Liberation War. First, the movement had to think of ways to strengthen its grassroots groups and structures at a more local level than otherwise. At big schools where many students joined the movement several groups were formed which would meet after some time, thus constituting a section. Sections from other schools in the locality would come together to form an area, out of which an area team would be elected to lead the local movement. At best, the local areas came together to form a region, which would again have elected persons to constitute the regional team to lead and coordinate the regional movements. These regional teams existed in the various corners of the Gwelo diocese and could not come together to form a diocesan committee under the current difficult conditions.

It is very interesting that the structures of the YCS/W movement shared some similarities with the rural community structures created by the Freedom fighters in their desire to smoothly mobilize the people. However, it is difficult to confirm that the YCS/W movement appropriated the Freedom fighters' method or modes of mobilization. Even so, it can be said that many YCS/W members were as much involved in the struggle for liberation as were so many youth in the schools or workers at missions and small towns, etc. ${ }^{12}$ What can be said with certainty, is that the YCS/W had methods and agenda that supplemented, if not partially coincided with, the goals of the liberation struggle. The struggle became more national and broad-based in scale, while the 
YCS/W remained regional. The success of the liberation struggle being waged by mostly young people and the revolutionary spirit floating in the rural areas may have contributed a great deal to the radicalization of the YCS/W movement.

Furthermore, the closure of most of the rural mission secondary schools in late 1978 and 1979 helped the movement spread to urban centers like Selukwe, Que Que, Gwelo, Fort Victoria, etc., where alternative or temporary schools were set up in churches or halls. The urban movement did not, however, become as strong as the rural one because of various intervening factors that differed from those in rural areas.

\section{EXPANSION AFTER INDEPENDENCE (1980-1988)}

\section{Early Reconstruction}

Independence brought peace and tranquility to a nation that was ravaged by war and strife. One of the most noticeable windfalls of independence was freedom of movement and association. Communication between people was restored: the whole nation was primed for a return to normality, to rehabilitation and reconstruction of the much needed infrastructure and services.

In May 1980, slightly more than a month after Independence, the YCS/W held a meeting at Gokomere Training Centre where the participants agreed to divide the movement into two autonomous movements, i.e. YCS and YCW to operate independent by and with specialized concerns and foci. Hence, the YCS would concentrate primarily on the student world and on areas requiring specific student inputs while the workers would concentrate on labor issues and related areas. $^{13}$

At a Weekend workshop organized by YCS and YCW in September 1980 in Gwelo, more precise perspectives on the roles of the two movements and of Christian youth in the new order were shared and developed. At the end of the workshop, ratification of the split of the YCS/W into YCS and YCW was unanimously agreed. The two movements then drafted a joint resolution to guide their members for the future. ${ }^{14}$

In the following years the YSC movement extended to new locali- 
ties: Teacher Training Colleges like Gweru and Mkoba as well as the University of Zimbabwe and other centers such as Empandeni Youth Training Centre, Foundres High School and St Bernhards' in Bulawayo and Mt Selinda in Chipinge.

The holding of the first National study session and council reflects the amount of work done in the two years, after Independence. At this meeting of group delegates, numbering about eighty, that converged at Chikwingwizha Seminary, $16 \mathrm{~km}$ south of Gweru, people were coming from all over the country. Topics for study and discussion ranged from changes in the educational curriculum, justice at School and in Church, penal systems at School and instant justice in both rural and urban areas perpetrated by the Youth Brigade supported by the ruling party, the clash between church and party meeting times, and the relation between the church and the poor.

\section{Peasant Solidarity Camps - a New Priority}

Soon the idea of holding a Peasant Solidarity camp was born. Holding a successful nine-day long work camp was certainly going to be an expensive exercise but nevertheless a worthy cause. Funds were needed to transport students to and from the place where the camp was to be held. Food, tools, and other items for the projects to be carried out were to be procured before the camp got underway. District officers in charge of agriculture, rural development and water resources and resettlement were to be constantly consulted to ensure that undue conflicts would not emerge. Most importantly though was the constant consultation with the local people with whom solidarity had to be expressed.

The place chosen by the YCS movement was a farm bought by government for resettlement of peasant farmers from the overpopulated communal lands. The occupants of the scheme were still in the process of settling down, constructing houses and clearing up the land in preparation for the impending rainy season. They had rudimentary farm equipment and had to depend on government-supplied food and government-supplied fertilizers for the first year of settlement. However, often government-provided services took time to reach the community because of some bureaucratic delays. ${ }^{15}$

The peasants were sometimes smarting under threats and warnings from politicians stressing that if the resettled people did not produce 
enough to sell to the Grain Marketing Board they would be dispossessed of these plots and driven back to overpopulated communal lands. Whatever levels of encouragement these warnings tend to instill in the members of these communities, they also create fear and a masterservant relationship between the politicians and the poor listeners. At worst, these paternalistic warnings and threats also revive the peasants' distrust and dread of governments, be they black or white. The legacy of moving the people around has remained fresh in the memories of the people since the colonial Land Apportionment Act of 1931. Although no people have been moved back and forth by the Independence government people still take these warnings seriously and this leaves some distrust of the government's intentions by the people.

As already implied above, most newly resettled communities lack clean water and sanitary facilities. They lack initial capital to build durable and attractive homes. What they have to start with are pole and dagga huts. Most of these people also lack draught power to enable them to clear and sow substantial parts of the allotted 12 hectare plots.

The nine-day camp proved to be a challenge to both the young students and the families that shared all they had with the children who had come to be part of their homes, doing domestic and field chores and any other work. Students with special skills in bricklaying and carpentry worked with the male members of the community in digging 'Blair toilet' pits and laying out floor and roof concrete slabs. Others fenced off fields from pastureland and cleared the land in preparation for the rainy season. Others designed and constructed brick-and-earth ovens for baking bread and cookies.

As the last day approached there was a pervasive spirit of victory and joy not so much because of the projects but because the resettlement community residents were baffled that the YCS students had spent more than a week working with them without expecting any returns. "When they first came accompanied by the Resettlement Officer of Shurugwi district we thought they were youth sponsored by the Government. We could not believe that the young people of today would do what they have done just for charity. As days went by we were convinced that they were not just here because the Government or party had asked them to. We did not hear any party slogans when they came together for reflections that they also invited us to be part of. The YCS students did not thrust their opinions down our throats as the 
Youth Brigade members sometimes do. We only pray that your young brothers and sisters in this community will follow your group's example."16

Similar Peasant Solidarity Camps were arranged in the following years. In 1985, for example, with the national team back in full force another most successful nationally organized peasant solidarity camp was held at Tagarika resettlement scheme in Takawira district, south of Fairfields. Over one hundred and twenty students from all regions, except Bulawayo attended. After the resounding success of the 1982, 1983 and 1985 work camps, the YCS movement, apparently, became convinced that peasant solidarity camps had to be carried out annually as the corporate praxis by the united movement as one of the concrete expressions of solidarity with the marginalised peoples of Zimbabwe. ${ }^{17}$

\section{Additional Emphases}

Apart from the peasant work camp that has become the norm for actions carried out within the milieu that can properly be called the society, it is interesting to note that the YCS actions have rather been restricted to visiting the sick in clinics and hospitals, and assisting with the teaching of adult literacy courses, There have, however, been a few exceptions, for example, some YCS groups started a fund-raising campaign in order to buy books for Mozambican displaced youths. ${ }^{18}$

While these small actions range from being charitable, mobilizing to conscientizing in most cases the YCS groups intended to make their actions "liberating". The actions are meant to liberate both the giver and the recipient.

I have already noted that from the very beginning Joseph Cardijn's Review of Life Method has been the basis of action/reflection/action in YCS. This has made the YCS movement the first fruits of what may properly be termed 'contextual spirituality', with a Zimbabwean patent, epitomized, and undergirded by a nascent but promising liberation theology. 


\section{NOTES}

1. Bex, A., St. Peters Harare, 40f.

2. "The African Young Students; Their Questions and Challenges", p. 15.

3. Zambia YCS Handbook, p. 21.

4. Ibid.

5. Ibid., p. 22.

6. Ibid.

7. Ibid.

8. "Mater et Magistra", para 236.

9. Ibid., para 237.

10. "In Search of a Liberating Pedagogy", p. 6.

11. Sr. Angelika Laub (Interview), 1984.

12. "YCS in Africa; The Students in Solidarity with the Smallest", 1984.

13. The writer was a member of the Students delegation at the Gokomere Training Centre after having joined the YCS/W in early 1979 at Gokomere High School.

14. Workshop resolutions, September 1980.

15. There was a general dissatisfaction at Hlabati resettlement scheme because of the food relief delays, which the YCS national team found to be a calculated political ploy by the District authorities to force their will on the residents. We arrived at such a conclusion because as soon as these authorities knew that the Deputy Prime Minister was coming to address the YCS and the residents, within two days a lot of food was transported to the residents and much more consultation started with them.

16. Burrough, P., Angels Unawares, London, 1989, p. 74.

17. "The Students in Solidarity with the smallest", in YCS Newsletter, November 1985.

18. Zimbabwe YCS Constitution, art 2. 


\section{Church and State in Zimbabwe and South Africa}

\section{Carl F. Hallencreutz}

In this paper I will explore two lessons which I learned from the Harare research project on Church and State in Zimbabwe, which seem to me to be relevant for continued reflections on the role of religion in the ongoing struggle for a South Africa freed from apartheid.' The first of these lessons concerns constitutional developments and the issue of policy on religion. The second is that interactions of Church and State - as well as within churches - after Independence are greatly influenced by interactions of Church and State and within different churches during the anti-colonial struggle or the process of revolutionary transformation of a given society.

\section{WHAT DO CHURCH AND STATE REFER TO?}

Whilst constitutional developments are important in the struggle for political liberation - and I agree with those who hold that such developments are particularly important in the struggle for a postapartheid South Africa - we should not adopt too limited a perspective on these developments. It does not suffice merely to assess and compare alternative constitutional documents. We also have to explore how the constitutional statement is adopted and implemented as well as the theoretical and practical considerations which inform such implementation. This means that when we study Church and State relationships in various countries we have to take note of the policy on religion of the political forces in the respective state. This is most important when we assess on-going developments in multi-religious contexts, and we have been convincingly informed of the fact that post-apartheid South Africa, too, will be a multi-religious society. However, before we speak of Church and State in the context of the political search for Liberation and Full Humanity, I will start with a formal note about State. 
When speaking of State in our context we should avoid a too formalistic understanding of the term. We should not limit our research interest merely to the structures and institutions of the Government in office, however critical our analysis of such structures may be. We have also to consider the nationalist movements who struggle for political freedom and mature human conditions for the majority of the people. That is, we have to consider what may be called the Government-to-be and how the churches interact and in the future will interact with that part of the State. ${ }^{2}$ In constitutional terms, thus, we have both to attach our attention critically to the prevailing constitution of the Government in office and to reflect imaginatively on the implications of alternative constitutional guidelines of the Government-to-be. ${ }^{3}$

If we adopt this perspective on the State in our assessment of Zimbabwean developments we soon realize that it has to be qualified in one very significant regard. We have to make note of significant differences in objectives and political approach of nationalist movements operating within the national context on the one hand and liberation movements who are operating from exile on the other.

In Zimbabwe this became painfully apparent after the constitutional conference in Lusaka in late 1974 and the increasing cleavage between, on the one hand, Bishop Muzorewa and his and others' ANC, and on the other, Robert Mugabe and his and others' ZANU - and later ZANU-PF. Actually there is a dramatic dialectic of timing and priorities emerging when we survey Zimbabwean Church-State interactions with these conflicts in mind. In order to properly assess these dialectics, however, we have also to specify what our cherished term Church refers to.

When we speak of Church here, I suggest that we first of all have in mind people who identify themselves locally with others, who share similar religious experiences and convictions. At the same time we have to reckon with specific structural and denominational differences. There are Christian communities of different kinds within what we call the Church. One important divide - not least in Southern Africa-is the difference between national churches with a double mandate, i.e. churches who cater both for the African population and European settler communities on the one hand, and regionally based Missionrelated churches with predominantly African membership on the other. Roman Catholic, Anglican and Wesleyan Methodist churches belong 
to the first category, whilst the great majority of mainstream Protestant churches belong to the latter. The so-called Independent Church Movements fall within a third category.

As far as ecumenical structures on the national level are concerned, which also are implied when we speak of the Church, the Zimbabwean scene provides certain features of its own. On the one hand, you have the parallel ecumenical structures since the mid-60s, i.e. the Zimbabwe Catholic Bishops' Conference (ZCBC) and Zimbabwe Christian Council (ZCC). On the other, you have a more informal-but highly significant - joint representation of different Church leaders, Roman Catholics included. That is the so-called Annual Meeting of Heads of Denominations, which after Independence has become increasingly important as an ecumenical forum for sorting out continuing issues in on-going Church-State interactions within the new political framework of sovereign Zimbabwe.

Having, thus, specified the terminology for our continued reflections on Church and State in Zimbabwe - and South Africa-I will now go on and briefly summarize the delicate and quite involved Church-State relations in Zimbabwe since 1965, which provide the necessary background for our attempt to assess on-going Church-State interactions after Independence.

\section{TIMING AND PRIORITIES IN THE CHURCH'S STRUGGLE FOR ZIMBABWE}

Ian Smith's Unilateral Declaration of Independence for Rhodesia in 1965 (UDI) was rejected by the Catholic Bishops' Conference and the newly established Rhodesia Christian Council. However, amendments in the Land Apportionment Act were proposed with a view to enforce registration of land tenure along racialist lines which caused more dramatic developments. These proposed amendments from 1969 and parallel revisions of the administration of primary education caused the furor of Father Randolph, S.J. of the Catholic Bishops' Conference. In order to co-ordinate a united Christian critique of the proposed racialist registration of land holdings, a wider ecumenical forum was formed. This was the Annual Meeting of Heads of Denominations.

The second major issue in Church-State interactions after UDI was over the Smith-Douglas-Home proposal for a settlement of relations 
between Smith's Rhodesia and Douglas-Home's United Kingdom. In this confrontation the Christian Council took the lead in active support of the emerging African National Council with the United Methodist Bishop Muzorewa and the Rev. Canaan Banana of the Methodist Church in the forefront.

In fact we can note a clear difference of strategy of the Bishops' Conference on the one hand, and the Christian Council on the other after the rise of the Rhodesian ANC. The Bishops' Conference continued to give priority to a continued critical interaction with the Government in office. In 1972 it established the Catholic Commission on Justice and Peace (CCJP) as an additional and very active means of disclosing the atrocities of the security forces and to counteract the official propaganda. The Christian Council, on the other hand, gave particular attention to interactions with the internal wing of the nationalist movement in the form of ANC.

With the escalation of the war since 1975 and the increasing cleavage between Abel Muzorewa and Robert Mugabe, who after the Lusaka Conference in 1974 emerged as the charismatic leader of ZANU, ecclesiastical priorities had again to be reviewed. Whilst pursuing its critical analysis of the measures of the Government in office, the Bishops' Conference for various reasons began to recognize the Patriotic Front - comprising both ZANU and ZAPU — as the potential Government to be. ${ }^{4}$ It refuted the internal settlement in 1977 and subsequent developments included the Lusaka encounter of Catholic Church leaders and the leadership of the Patriotic Front in $1978 .^{5}$

On the Protestant side the political stand of Bishop Muzorewa increasingly proved to provide problems. However, the Christian Council gave-most conditionally - the internal settlement a try, although the distinguished Garfield Todd decidedly articulated his critique of conditions under the settlement and managed to carry the Council with him. In 1979_-prior to the Lancaster House negotiations - the Council launched its specific Reconciliation Mission, which paved the way for new and more direct interactions also with the newly co-ordinated Heads of Denominations which was entrusted with the task of administering the ecumenical representation at the Independence Celebrations in April 1980 and which also was commissioned to far-reaching services for the reintegration into Zimbabwean society of former refugees. 


\section{RAMIFICATIONS AFTER INDEPENDENCE}

The interactions during the war, of course, informed subsequent developments after Independence. One significant change was the new role of the Roman Catholic Church in interactions with the new Government, as illustrated by Bishop Mutume.

Ian Smith had claimed to defend Christianity and Western Culture in Central Africa. With his own Presbyterian affiliation and with the active support he enlisted from the Anglican Bishop of Harare, Rt. Rev. Paul Burrough, Smith did not allow the Catholic Church immediate access, even if there were staunch supporters of the Rhodesian Front among substantial groups of white Catholics.

With his own links to the Catholic Church, Robert Mugabe and other distinguished Catholic lay-persons whom he brought to office, provided new opportunities for contacts for the Catholic leadership to the new administration, although the PF Government explicitly opted for a secular policy of religion. However, President Mugabe has continued to recognize the role of the Church as partner in the Liberation Struggle and reinforces his emphatic call to the churches to be actively involved in the continued struggle for national reconstruction and development.

Developments on the Protestant side immediately after Independence implied certain problems. In addition to the confessional claims of Ian Smith there was also the potential clash within the Christian Council of loyalties, on the one hand to the new Government and, on the other, to Bishop Muzorewa and his political objectives. The problems came to a head in November 1981, when the then State President, the Rev. Canaan Banana, publicly accused the Council of passively sitting on the fence, observing which direction sovereign Zimbabwe would take.

Having emerged as an outspoken Vice-President of the Rhodesian ANC in 1970, Rev. Banana, with subsequent experiences both from continued studies in USA and from Rhodesian jails, crossed the floor during the Constitutional Conference in Geneva in 1976. He left the UANC delegation under Bishop Muzorewa and joined the ZANU-PF delegation under Robert Mugabe. When Joshua Nkomo turned down the offer of State Presidency of Sovereign Zimbabwe in 1980 the call fell on Rev. Banana. In that capacity he has energetically pleaded for a 
radical and sincere participation in nation building, not least from the side of the Protestant churches. ${ }^{6}$

From November 1981 to May 1982 there was, thus, a tug-of-war between State House and ZCC Headquarters. However, an agreement was reached and the $\mathrm{ZCC}$ has since embarked on a comprehensive mission of development education and co-ordination of development planning of its member churches. ${ }^{7}$

At this point an additional comment should be made on the role of Heads of Denominations after Independence. With the differences of priorities and timing of the Bishops' Conference, on the one hand, and the Christian Council, on the other, which I have illustrated above, the Annual Meeting of the Heads of Denominations was not able to fully co-ordinate the ecumenical strategies during the 1970s. The situation improved somewhat from 1978 onwards. After Independence, however, the Heads of Denominations has been reinforced as a unifying ecumenical forum, which provides a base for quite involved interactions between representatives of Church and State on national issues. Already at the first annual meeting after Independence the State President, the Rev. Canaan Banana was the main speaker.

Of course, after Independence, too, we shall continue to make a qualified use of our concepts Church and State. Also within a new and very different political framework the Church continues to manifest herself as a multi-dimensional entity where the local base is very important, but where ecumenical structures on the national scene will provide significant channels to the relevant Government agency. Sometimes there may be interesting divergencies in perspective and priorities between church members on the local level and the leadership on the regional and national scene.

When we speak of the State we shall also bear in mind the multidimensional content of the term even after Independence. We cannot limit ourselves merely to the new Government in office with its institutions and structures. Although that Government carries the responsibility as the prime heir of the Liberation Struggle, the Church has to define her role prophetically in the dynamic interaction between the State and the people. It is within that framework that the Church is called to pursue her prophetic ministry on behalf of and together with the poor and the marginalized. It is as such she can play her role as an autonomous partner in national development. The continued ministry 
of the Catholic Commission on Justice and Peace within its new structural framework provides interesting examples of what can be at stake. It also illustrates the cost of such discipleship.

\section{POLICY ON RELIGION AND THE ANC CONSTITUTIONAL GUIDELINES}

Experiences from Mozambique and interactions with Zimbabwean Church leaders informed Robert Mugabe's and the ZANU-PF leadership's policy on religion since the party in 1977 had adopted MarxismLeninism adjusted to Zimbabwean conditions as the ideological thrust of the Government-to-be in Zimbabwe. On this basis the PF-Government in office in sovereign Zimbabwe is implementing a remarkably generous policy on religion with certain features of its own. ${ }^{8}$

In one very significant regard conditions differ when comparing Zimbabwean and South African developments. The time from the adoption of a constitutional blueprint of the Government-to-be - I am referring here to the adoption of the Freedom Charter in 1955! — to the actual implementation of this blueprint in post-apartheid South Africa is, alas, much longer than was the case in Zimbabwe. However, with the updating of the Freedom Charter in the form of ANC Constitutional Guidelines we have reached a new and decisive phase in the constitutional development in South Africa. As the Church was involved in the formation of the Freedom Charter, she is now invited to contribute to the "extensive and democratic debate on these guidelines" as a significant means of achieving lasting political change in South Africa. ${ }^{9}$

I suggest that there are three important dimensions in the issue of policy on religion, which also are implied in the ANC Constitutional Guidelines. The first dimension necessarily has to do with religious liberty, i.e. the question of freedom of creed and participation in corporate religious fellowship. Freedom of religion, thus, is both an individual and a corporate affair, where the latter implies the freedom of religious communities to perform their mission within a given constitutional framework.

I read the ANC constitutional Guidelines as implying a recognition of both forms of religious liberty in post-apartheid South Africa, and I 
find this very significant. What I am particularly referring to is the following formulation in the preface of the Guidelines:

There shall be equal rights for all individuals, irrespective of race, colour, sex or creed. In addition, it requires the entrenching of equal cultural, linguistic and religious rights for all. ${ }^{10}$

This, I think is a realistic and most relevant target for the search for a democratic South Africa, which takes the multi-religious composition of the society seriously. It illustrates very clearly the blatant irrelevance of the present South African Constitution, which the churches in South Africa have already declared obsolete. ${ }^{11}$

The second dimension of policy on religion has to do with the way in which the Government sees its institutions and structures being directly or indirectly informed by religious and/or ideological considerations.

An intimate interaction between national political and religious structures, is, of course, the predominant feature of traditional and traditionalistic policies on religion. Such policies certainly were reinforced in Europe after the Reformation, and they informed the confessionalism of emerging European nation-states. Conditions changed after the American and the French Revolutions in 1776 and 1789 respectively - and even more dramatically in the Russian Revolution in 1917. These political transformations brought to the fore alternative views on the Secular State.

The present South African Constitution implies a confessional policy on religion, i.e. it allows a specific theological perspective to inform the policies of the Government in power. At this point we could insert a reminder also that there are preferences for confessional policies in states where Islam is the majority religion, although the theological orientation differs in such states compared to that of the South African government in office.

At this point as well, the ANC Constitutional Guidelines clearly deviate from the present South African Constitution and make it obsolete. These guidelines opt for a secular policy on religion for multireligious South Africa after apartheid. The role which religious groups will play within the anticipated framework will depend very much on the present interaction between the churches and the Government-tobe and on the way in which the new Government will implement its constitutional guidelines. In this way we approach the third dimension 
of policy on religion, which has to do with the way in which a Government deals with religious groups as either partners or threats in the search for national integration.

There are both ideological and structural issues involved here. The ideological issues contain inter alia specific views of religion as a human and social phenomenon. Instead of generalizing on the basis of the process of secularization in the Western World, it seems to me to be more valid for a prognosis and continued reflection on future ChurchState interactions in South Africa to consider in how far the Church in the process of the present struggle interacts with the Government-tobe. Furthermore, religious developments in post-apartheid South Africa will depend on the deliberate way in which the Government will allow creative interaction between religious groups and its own political structures and mass organizations

\section{THE CHALLENGE TO THE CHURCHES}

Issuing their Constitutional guidelines ANC invites churches inside and outside South Africa to an intensive palaver - the guidelines speak of "extensive and democratic debate ${ }^{\mathrm{u}}$ - on the relevance of these guidelines as a blue-print for South Africa freed from apartheid. ${ }^{12}$ With the great tradition of intimate interactions between Christian leaders and the ANC since the formation of the movement in 1912 in mind, and against the background of the broad Christian participation in the process which led to the adoption of the Freedom Charter in 1955, I would assume that this is a cherished task for South African churches, although for some who are divided along racial and political lines this exercise may be quite demanding. ${ }^{13}$ There will, alas, be specific issues to face for churches who are caught up in the painful conflict between ANC/UDF on the one hand and Inkatha on the other.

These issues, however, have to be faced in the search for a contextual theology in South Africa. The ultimate question in the end, is whether there in actual fact are any real constitutional alternatives to those of ANC and, if so, how they should read. It is now that this question has to be tackled.

The forms in which the churches' are involved in the struggle for a democratic South Africa will continue to differ. But the invitation to share in the palaver on the Constitution for a future South Africa freed 
from apartheid should not be overlooked. This seems in fact to present itself as a most relevant additional element in the search for a contextual theology which also takes the theology of exile into account. In this regard we are again reminded of the implications of Lusaka 1978, to quote the nearest Zimbabwean parallel.

The continued dialogue between the Church from within South Africa and the Liberation movement operating from bases in exile on the proposed constitutional guidelines will also raise additional issues. I imagine that the question of how the churches in South Africa can prepare themselves to welcome and utilize the resources of those who are now in exile and will return to a South Africa freed from apartheid is one of these.

\section{NOTES}

1. C. F. Hallencreutz \& A. Moyo (eds), Church and State in Zimbabwe 1965-1985. Mambo Press. Gweru 1988.

2. It is interesting to note that this distinction is made in the so-called Lusaka Statement, May 1987, and further elaborated in F. Chicane's courageous paper 1988: A Turning Point for the Church in South Africa.

3. Cf. Mrs Duncan's contribution in this volume.

4. A more detailed analysis is advanced in C. F. Hallencreutz, A Council in Cross Fire, in Church and State in Zimbabwe, 51-113.

5. Cf. Bishop Mutume's contribution in this volume and his, "The Priority of the Zimbabwe Catholic Bishop's Conference since Independence", in Church and State in Zimbabwe, 461-475.

6. On C. Banana's theological position, see further P. Gifford, The Role of the President: The Theology of Canaan S. Banana, ibid, 411-440.

7. See further C. F. Hallencreutz, Ecumenical Challenges in Independent Zimbabwe, ZCC 1980-1985, in ibid, 264-275. Cf Dr Chepkwony Ongaro's contribution in this volume.

8. See further C. F. Hallencreutz, "Policy of Religion: The New Framework", in Church and State in Zimbabwe, 12-18.

9. Constitutional Guidelines for a Democratic South Africa, issued by the ANC, Lusaka.

10. Ibid.

11. See further The 1987 SACC National Conference Resolution on Legitimacy of the SA Government, and The Statement of Church Leaders, 25 February 1988.

12. Constitutional Guidelines, p. 1.

13. See further R. Sutton \& J. Cronin, 30 Years of the Freedom Charter, Ravan Press, Johannesburg 1986. 


\section{The Role of the Church in the Development Market — the Case of Zimbabwe}

Agnes Chepkwony Ongaro

During the past three and a half decades, plenty of research work has been undertaken on the process of economic and political development in the Third World. Development as a concept and as a process has occupied a central place in the literature. The conception of development ranges from a goal through to an end product, to a set of policies. Thus, development studies have, in the course of time, emerged and become a recognised academic discipline with an advanced theory and a refined methodology. In most cases, major attention has been afforded to theoretical issues and an assessment of political options of development strategies in the respective countries as well as to the achievements and failures of particular economic policies adopted. ${ }^{1}$

As the third Development Decade unfolded, it had become evident that development of the type experienced in the last quarter of a century by Third World countries and especially Africa, had adverse effects on the vast majority of the people: It has meant increased impoverishment and, despite registered economic growth, there are no tangible indicators that growth as such has benefitted the poor or for that matter succeeded in reducing the occurrence of poverty. Indeed, as Hellinger et al. (1988:26-27) aptly state, the trickle-down aid and the development approach adopted for a quarter of a century were consistent with the interests of the economically powerful. ${ }^{2}$ At the same time, in 1979, the President of the World Bank, Robert MacNamara engaged in a policy dialogue that laid the foundation for Structural Adjustment Lending (SAL).

The argument advanced for this policy was that Third World countries had been pursuing "wrong policies". The African countries were in particular singled out as the main culprits. Hence in 1980, the World 
Bank policies (SAL) converged with those of the International Monetary Fund (IMF) designed to promote economic stabilisation, and known as Structural Adjustment Policies (SAP).

\section{INTRODUCTION}

It is beyond the scope of this paper to venture into the effects of SAP. However, the story of SAP and the people's struggles for survival have become common features in the press and mass media. This being the case, there emerges an additional issue: where in the game do nongovernmental organisations fit? ${ }^{3}$

This paper represents a modest effort to outline the role of nongovernmental organisations (NGOs) and in particular, Protestant churches and Church-based NGOs in the development process in Zimbabwe after the attainment of Independence in 1980 to 1988. Given that development policies have in general failed to address the fundamental causes of poverty and profound inequities in wealth, we have to ask, does the Church have a role, if any, in the development process that is currently under the influence of SAP?

I shall submit that the Church as an NGO is a potential agent of socio-economic change. Furthermore, I claim that the potential of the Church can best be realised if the terms and forms of relationships she enters into with the other major actors in the development market reflect the inherent qualitative nature which includes an ability to undertake responsible advocacy, particularly for the hoi polloi, which is Greek for many, or the people who form the arena and is the very agent of development.

\section{NON-GOVERNMENTAL ORGANISATIONS: A FACTOR TO RECKON WITH}

Interest in the role and nature of non-governmental organisations (NGOs) has within the last fifteen years gained tremendous momentum. The interest to understand the role of NGOs has been precipated by the rate at which these organisations have emerged in the Third World and especially in Africa south of the Sahara. To illustrate the 
rapid growth of NGOs, Hellinger et al. observe that in 1984, some 2,200 Northern NGOs used approximately US\$ 4 billion in assisting about a hundred million people in the Third World. This figure excludes the number of Southern NGOs, sometimes referred to as indigenous NGOs, and their own resources. Further, Hellinger notes that the amount of money spent in 1984 by Northern NGOs represents a threefold increase since the mid-1970s. There is no one agreed-upon definition of NGOs. In fact Landim (1982:30) argues that the name $\mathrm{NGO}$ is in the first place an inadequate concept, as it fails to define the phenomenon empirically. In addition, the term NGO was coined in the industrialized countries of the North where the relationship between the civil society and the state has a different dynamic. ${ }^{5}$

What Landim is pointing out is an essential point that has farreaching consequences. To begin with, while NGOs enjoy amicable relations with the state in the North, it is the opposite in the South, where the state views independent activities of the civil society with suspicion. Thus, inasmuch as NGOs in the North may have possibilities to influence the state and even openly dialogue with it on crucial policy issues pertaining to the development of a nation, this may not necessarily be the case in the South.

In this paper, $\mathrm{NGO}$ is used to refer to private non-profit organisations that are welfare-oriented and registered with the government. The Church, although treated in this paper as an NGO, is in most cases treated differently as its right to exist in most countries is engrained in the Constitution under the section on Bill of Rights. Therefore, the purpose of the Church is not completely the same as that of secular NGOs. The principal function of the Church is the propagation of the Christian faith. Development projects or welfare services (diakonia) are perceived to be part and parcel of this primary function - i.e. ministering to the spiritual needs of the followers and building up religious communities and institutions. It can, in the case of Africa, be argued that there is a link between the growth and expansion of NGOs and the general decline in socio-economic development. The rapid expansion of NGOs is not an isolated phenomenon. Rather, it is closely related to the socio-economic crisis and the development strategies designed thereafter by international institutions in an attempt to reinvigorate economic growth admidst a grave economic crisis fuelled by the debt burden. What then is it that makes NGOs a viable option as agent of 
change? Judith Tender has provided the most suggestive answer to this question. She has listed not less than 8 points in what she calls the articles of faith of secular NGOs:

1. Although NGOs provide a small segment of the globe's assistance, they tend to direct, target and assist the poorer elements in the community effectively and efficiently;

2. NGOs ascertain local needs and priorities, base projects on local inputs, transfer know-how appropriately and organize and/or strengthen local institutions;

3. NGOs provide pressure-groups in rural areas or low-income parts of urban communities which facilitate the organisation of people to serve their own needs;

NGOs tend to be experts because of their voluntarism and willingness to live very simply, often costless. They live with the poor and have simple structures, which has led to the belief in NGO efficacy;

4. NGOs are well positioned to try out new ideas and techniques;

5. NGOs function economically due to their size and use of volunteers. They are also flexible. Their size allows for decentralised decisionmaking process and structure;

6. NGOs have an advantage of acting quickly and this has made it possible for them to be frontline warriors in the battle against the great famines of the late-1970s and the early-1980s as eluciated by the British Band Aid;

7. NGOs are independent of governments and are therefore able to develop demands for public services and resources, thereby facilitating work of a government ministry in a rural area; and further;

8. NGOs are believed to be responsive, familiar with local environment, supportive of truly poor, builders of self-reliance, flexible and innovative and participatory throughout the project cycle. ${ }^{6}$

Most of the above attributes have been derived from secular NGOs although religious NGOs do share many of these articles of faith. But the emphasis on secular NGOs has meant that the role and constraints of local religious movements in the development market has not always been sufficiently appreciated and analysed.

Besides having a long history of involvment in welfare and relief services, the Church is probably the only well organized institution 
other than the state in many Third World countries. There is ample evidence to suggest that at the time of independence, mission agencies and churches were well entrenched in the development process. In fact, the Church was the pillar of what is known to-day as social services in Africa. As most countries achieved independence, this dominant role of the Church was diversified as a number of secular NGOs emerged and as NGOs from Europe and North America moved in. The story of the growth, performance and type of relationships that exist between these churches and NGOs varies from country to country. We shall now focus our attention on a country which emerged recently out of a harsh and long colonial experience in order to find out how the Church has operated as a NGO after Independence.

\section{THE CHURCH AND NGOS IN INDEPENDENT ZIMBABWE}

Zimbabwe is a country which, despite a prolonged war of independence, attained its liberation only in 1980, at a time when shifts in theoretical discussions and development strategies had begun to take place. The post-independence experiences of Zimbabwe are largely characterised by these changes, i.e. the socio-economic crisis, the destabilization policies of the racist regime in South Africa, and the thrust of NGOs as agents of development. Thus, Zimbabwe is a country which, due to the SA destabilization of the Frontline States, has a war bill which runs to about 5 per cent of the GDP. It should, however, be stated that economic growth has so far superseded the demands of the population growth. Further, having opted for a Socialist oriented development, the government has pursued strategies that are about to achieve access to universal basic services, that is, education, health, water, etc.

In spite of the Socialist ideology of the Zimbabwe African National Union/Patriotic Front (ZANU/PF), there was a qualified emphasis within ZANU/PF policy of national development on nurturing the traditonal heritage due to the religious factors that operated in a significant way in the people-oriented strategy of ZANLA guerillas during the war. ${ }^{7}$ Professor Ragner suggests that in the development strategy adopted after independence, ZANU/PF has qualified its interaction with African Traditional Religious institutions and structures. It is also keen to solicit the co-operation of the churches in the 
development process. Recognition has been made of the contribution to rural health and education in communal areas by mission agencies and churches, as well as the support given to the freedom fighters by local Christians. The contribution of local Christians during the war and after has not yet been adequately explored in a historical study of Zimbabwe's second war of independence, an area which is beyond the scope of this paper. Nor has the interaction between the Church and State in socio-economic development received enough space in scholarly work, except for the recent volume on Church and State in Zimbabwe (eds. C. F. Hallencreutz and A. Moyo, 1988). ${ }^{8}$

My preliminary findings after a period of field study contain the following: The role of churches has been a multifacetted one. This meant that between 1979 and 1983, the churches participated actively in the repatriation and rehabilitation of refugees and in reconstruction. The Zimbabwe Christian Council (ZCC) established a reconstruction committee to oversee the implementation of programmes. Funding for reconstruction was coordinated by the World Council of Churches (WCC) in Geneva. About twenty-seven churches participated and approximately $\$ 6.5$ million was raised, of which 20 per cent came from ecumenical partners and the rest from the government, people and former mission agencies. In 1982, the churches embarked on resettlement programmes and they initially agreed that there would be a scheme in each province but this has not been realized. Faced with the drought, churches continued to render relief services.

In about 1983, churches initiated a process leading to a committment towards development. "Towards a New Society and Joyful Witness" was the theme. Member churches of ZCC were asked to identify development priorities and in order to do that several regional seminars were held in different parts of the country which culminated in a national conference on "Self-liberation to Self-Development". Priority issues outlined in 1984, were inter alia: evangelism, water, agriculture, health, education, rehabilitation, community centres and infrastructure, leadership training, women and youth. As can be noted, most of these priorities, with the exception of evangelism, converged with government policy objectives.

In undertaking these priorities, the mission station remained the locus of activity, particularly for health and education activities. As late as 1983 , the churches stood for 65 per cent of rural health services, 
which corresponded to about 44 per cent of health services for the country as a whole. To illustrate the prominent role that health occupies in the activities of the churches, an organization known as Zimbabwe Association of Church Hospitals ( $\mathrm{ZACH}$ ) was formed and has direct contact with the Ministry of Health.

On the basis of these findings, I move on to a more structural analysis.

\section{DYNAMICS AND OBSTACLES IN CHURCH INVOLVEMENT IN DEVELOPMENT}

The involvement of churches in the development market can be categorized as follows: social welfare and relief services (Christian Care still shouldering the responsibility); social development services which include community organization, health, development education (Learning for Social Transformation), youth, water and sanitation, and the development of church capacity (training of personnel); women groups known as "Vashandiri" (the type of projects that women run do not correspond, however, with the power they have in sustaining the church); production and economic development: agriculture and livestock, credit and income generation (this is a relatively new thrust which has not fully been developed); spiritual and pastoral care. In order for the local churches in Zimbabwe to pursue reconstruction, rehabilitation and development activities, other actors in the game have been involved. ${ }^{9}$ I highlight the following: First, the role of WCC in coordinating requests to ecumenical partners has been crucial, a role which they initiated during the UDI years. The relationship between WCC and ZCC leadership encountered tensions over the perception of development which in 1980-82 apparently differed. This constrained relationship which started in 1979 as churches planned their reconstruction activities, affected the early flow of resources. ${ }^{10}$

Secondly, unlike secular NGOs, many of the churches and churchbased NGOs in the North did not open field offices, except for the LWF and a few others. But even in the case of the LWF, a gradual integration progress has taken place with the local Lutheran church; whatever "integration" here may mean.

With the new General Secretary in 1983, the ZCC organized an international conference in 1985 at which ecumenical partners pledged 
on the basis of the shopping list provided by the churches through ZCC. In 1986, international conferences were replaced by the establishment of the Round Table. The Round Table mechanisms have functioned in other countries for some years now and their model in terms of relations varies widely. One of the main purposes of this arrangement is to reduce bilateral negotiations and reporting which is cumbersome, and also to break the power of the donors. "

This was a move in the right direction when compared with the past practice where the churches submitted their programmes and had no idea of whether they would get funding or not; where they had to dialogue with every individual donor on some individual projects. The Round Table model still has weaknesses of, for instance, exposing the local churches weakness to the donors, while they themselves have little or no knowledge of how donor organisations function.

Thirdly, churches have very little direct contact with Public Bilateral or Multilateral Institutes (BMI) or embassies as most resources come via Northern NGOs like ICCO, EZE, Bread for the World, etc. It should be pointed out that inspite of the Round Table arrangement and its intentions, those donors who receive most funds from their governments, e.g. ICO and EZE in the Netherlands and West Germany respectively, still insist on extra reporting.

Further, the Round Table mechanisms aim to create a certain equality between "receivers" and "donors" and between "small" and "big" donors. This, however, is far from being realised. One of the reasons is that the big donors still wield a lot of power even at a Round Table arrangement, especially as the monitoring mechanisms for the implementation are so weak. The other reason is that churches are still relatively weak and this is reinforced by the lack of a definite clarity on the type of development approach they want to pursue. Many a church leader still conceives development as a catalogue of projects.

Moreover, few donors would be willing to relinquish power of decision-making to the people, if they were to opt for a development orientation that threatens the very existence of the donors. Hence, inasmuch as the Round Table model has improved donor-recipient relations, it still exhibits imbalances in power particularly regarding issues of management of resources and programmes. There are a few donors at the Round Table who want to explore an alternative model that can really "strengthen the poor" but the obstacles are both at the 
level of other donors and intermediary bodies in the national situation. $^{12}$

Fourthly, the churches are, on the one hand, increasingly far removed from their traditional partners as the $\mathrm{ZCC}$ is charged with the full responsibility of coordinating all fund-raising and its disemination to the churches and grass root groups. On the other hand, both ZCC and churches have increasingly limited contact with Northern NGOs. Consequently, at both national and international level there are many intermediaries operating with a view to empowering grass root communities to improve their quality of life.

Herein lies a crucial concern on the question of power. Namely, how do the churches understand power and their role in transferring that power to the people. Unfortunately, the chain of intermediaries is long and the hoi polloi are far removed from the centre of power and decisionmaking over their development destiny. This is a chain that continues to enhance dependency rather than self-reliance.

Fifthly, the churches do realise the lack or limited capacity to fully and meaningfully engage in the development market. As a result, ZCC has requested all churches to set up development desks with development officers. Some churches have fulfilled the requirement but others, due to lack of resources, have not.

This move has at least two implications: One is that ZCC and the member churches have put priority on development and are recruiting academics or professionals (AP) on their staff either as fulltime or as consultants. Furthermore, church personnel is in the process of becoming heterogeneous as the traditional recruitment base widens to include other groups like APs. The variety is reflected in the levels and types of training, work ethics, perception of the church and even terms of service. The Lutheran Development Service (LDS/LWF) is a good example of this change.

A sixth point has to do with inter-NGO coordination. At the national level, there are the Voluntary Organizations in Community Enterprise (VOICE) for all organizations working in Zimbabwe and also ZCC for most Protestant churches. The aim of VOICE is to provide coordination and sharing of information within the NGO community and in relation to the Government. From some of those interviewed, a number knew of the existence of VOICE but had little contact, and others feel that VOICE as a coordinating agency is not that effective 
and do not therefore take it seriously. It was observed that most of the coordination was at the provincial level through local government administration. Besides registering with the Ministry of Foreign Affairs and relating directly to the relevant ministry, many of the NGOs/ churches had no effective national coordination and supervision.

In view of the absence of effective coordination, a sense of competition exists between donors and churches for space, programmes and beneficiaries. Such competition has in certain cases led to duplication of projects and structures. Replication of regional committees and microprojects by ZCC and Christian Care is one of the many examples. With the limited capacity for management and planning, the competition has hampered the sharing of expertise, which leaves churches and NGOs with a limited micro- and macro-analysis on which to base their interventions. Hence the tendency for a haphazard response to needs as they arise and a lack of horizontal networks among people to facilitate the sharing and multiplication of experiences.

\section{INTERACTIONS WITH THE STATE}

My final observation concerns interactions with the State on the ideological level. As already noted, the policy of religion of the ruling party has been conducive to church participation in the development market. The President Mugabe, former President Banana, and other government officials have participated in various church meetings, including the two major ZCC international conferences that set the pace for development activities and priorities. The application of the Socialist ideology has not in any significant way hindered church involvment, partly because the implementation of the Socialist project has been slow given the nature of the political economy of the country. But even with this slow process, Protestant churches tended to be fence-sitting for quite some time due to the Smith propaganda against "communism". Now, however, when Socialism has taken root, many church leaders argue that Socialism as practised in Zimbabwe is compatible with their faith and African traditions. The real test of compatability or incompatability has yet to be faced by churches.

Reflection on the relationship between Marxism and Christianity has been left to a few people. Even books such as those written by C. S. Banana, seem for unknown reasons not to have penetrated pastors and 
the leadership. There are, however, a few instances in the churches, e.g. in the Lutheran church, where such a reflection has started at a grass root level with the help of LDS. Even so, the actual participation of churches and the nature and scope of their interventions have in the last nine years been determined by a relationship with the state which in most cases has endorsed state policies. This critical analysis raises further questions. Are churches as NGOs in fact as good at empowering the poor as their reputation suggests? Do they really have comparative advantages that make an argument for a rolling back of the state as an agent of development: That is, a reversing from public services and public sector orientation to the promotion of private enterprise, domestic and foreign alike? Have churches maximized their advantages? If the so-called economy of affection is so prevalent, are the churches also not caught up in it? To what extent has the mandate of the church enhanced or been a constraint in her involvement in the development market?

Having assessed more carefully the material gained in my field study I will explore these issues further. My interpretative perspective will then be informed by a painful awareness of a cleavage between contemporary ecclesiastical praxis and the ecclesiological ideal of a Church of the Poor. My problem can be illustrated in this way:

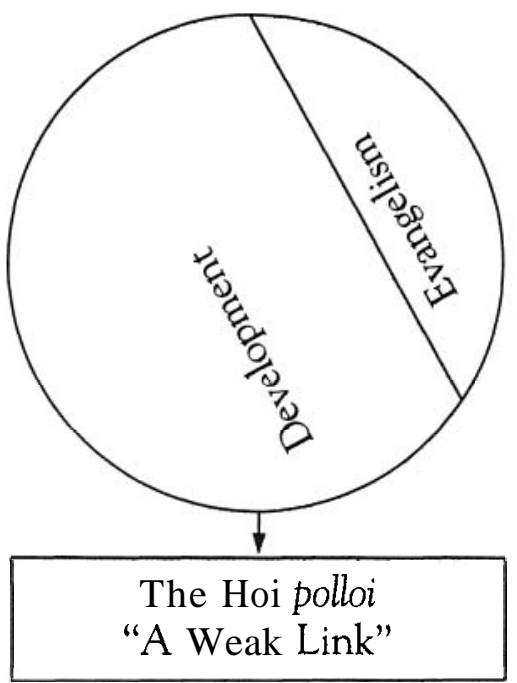

A: The Current Situation

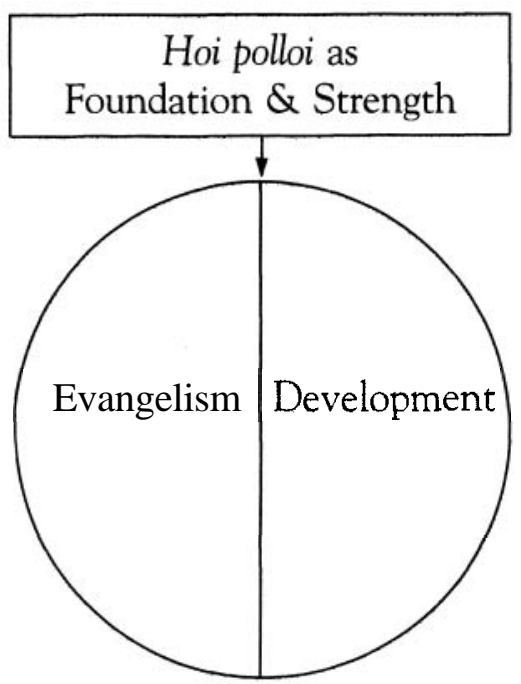

B: What Ought to be the Situation 


\section{NOTES}

1. There are two strands of thought within the Dependency school which have challenged the neo-classical approach of economic growth. On the one hand, there are "institutionalists" such as Seers and Lappe who have been critical of economic growth theory, arguing that even when economic growth has been rapid it has not benefitted the poor. Lappe even goes further and states that under such conditions Official Development Assistance (ODA) cannot help the poor because it only reinforces the already existing power relations which, in this case, represents a narrow elite with power in the form of government and economic interests, while the poor majority lack both political and economic power. And on the other hand, Griffin and Khan (pp. 229), representing the structural school, contend that it is not the lack of resources nor lack of economic growth, but that poverty is a feature resulting from an economic structure which thrives on inequality, inequitable distribution of wealth and assets, e.g. it is land which is crucial. Aid is, in this case, part of the problem and not the solution to poverty.

2. Hellinger, S. et al. (1988), 99.

3. See A. Chepkwony (1987) where, in the case of Kenya, it is indicated that social services, especially housing were argued by IBRD to be the concern of the individual and not the priority of the state (pp. 72-74).

4. Hellinger, S., et al. (1988), 99.

5. Landim (1982), 30.

6. See further Tender (1982).

7. See further Lan (1985) and Ranger (1985 and 1988).

8. Note that research work is being undertaken by a number of people, e.g. Sister J. Maclaughlin at the University of Zimbabwe, and there are a few articles in C. F. Hallencreutz \& A. Moyo (1988) pertaining to this topic.

9. For further details, see Kuchera, C. M., van der Poort, K. \& Ziswa, V. (1986) and van der Poort, K. (1987).

10. WCC had been involved in Zimbabwe during the war by offering scholarships and welfare assistance through ZCC and Christian Care and by providing humanitarian assistance to the liberation movements ZANU \& ZAPU PF.

11. C. F. Hallencreutz \& A. Moyo (1988), pp. 25-257 and 265-267 for further information.

12. See Chepkwony Ongaro et al. (1988: June) on the discussion on the Sudan Round Table and its involvment in the refugee programme with SCC.

\section{BIBLIOGRAPHY}

Ajayi Ade, J. F. "Expectations of Independence", In Daedalus, Vol. III, No. 2, 1982, p. 5. 
Banana, C. S. (1982) Theology of Promise, Harare, Zimbabwe. - (1987) Towards a Socialst Ethos, The College Press, Harare.

Bratton, M. "The Politics of NGO Government Relations". Paper presented at a conference on the Role of Indigenous NGOs in Relief and Development, Khartoum, January, 1988.

Chambers, R. "Thinking about NGOs Priorities". Background paper for the Oxfam Workshop on Arid Lands Management, Cotonou, Benin 23-27 March, 1987 (mimeo).

Chepkwony, A. (1987) The Role of Non-Governmental Organisations in Development: A Case of NCCK, 1963-1978, Uppsala.

Chepkwony Ongaro, A. "Church in Development: The Role of NGOs". A paper presented at the first Institute of Church Leadership in Development in Africa, organised by LWF, 10-07-1988, Makumira, Tanzania.

- et al. "Sudan Council of Churches". Involvement in the Refugee Problem: An Evaluation", WCC, Geneva, June 1988 (mimeo).

Chung, F. \& Ngara, E. (1985) Socialism, Education and Development in Africa: A Challenge to Zimbabwe. Zimbabwe Publishing House.

Fowler, A. "Management at Grassroots Level for Integrated Rural Development in Africa with Special Reference to Churches". Working paper No. 419, NDS, University of Nairobi, 1984.

- New Scrambles in Africa: "NGOs and their Donors in Kenya", January 1988 (mimeo).

Gifford, P. (1988) The Religious Right in Southern Africa. Baobab Books.

Gorman, R. F. (ed.) (1984) Private Voluntary Organisations as Agents of Development. A Westview Replica edition.

Griffin \& Khan, A. R. "Poverty in the Third World", In World Development, Vol. 6, No. 3, March 1978.

Hallencreutz, C. F. \& Moyo, A. (eds.) (1988) Church and State in Zimbabwe. Mambo Press.

Hayter, T. \& Watson, C. (1985) Aid: Rhetoric and Reality. London, Pluto.

Hellinger, S., Hellinger, D., Obrien, F. M. (1988) Aid for Just Development: A Report on the Future of \& Foreign Assistance. Lynne Rienner Publisher.

Hyden, G. (1983) No Shortcuts to Development: African Development Management in Perspective. Heinemann, London.

Kenya (1969) Second Development Plan, 1970-1974. Government printers, Nairobi. Kinyanjui, K. "The Church and Development" Nairobi, All Africa Conference of Churches Bulletin, Vol. XII, No. 1, pp 25-31, 1982.

Kuchera, M. C., van der Poort, K. \& Ziswa, V. (1986) Government Funding in Zimbabwe: A Report, Harare/Utrecht.

Landim, L. "Non Governmental Organisations in Latin America", In World Development, vol. 15, supplement, 1987, pp 30.

Lappe, F. M. (1980) et al. Aid as Obstacle.

Land, D. (1985) Guns and Rain: Guerillas and Spirit Mediums in Zimbabwe. London. Nichols, J. B. (1988) The Uneasy Alliance: Religion, Refugee Work and US Foreign Policy. Oxford University press, Oxford. 
OECD (1987) Development Cooperation: A Report.

Okullu, H. (1974) Church and Politics in East Africa. Uzima Press, Nairobi.

Ranger, O. T. (1985) Peasant Consciousness and Guerilla War in Zimbabwe. Zimbabwe Publishing House, Harare.

Scmidt, E., Blewett, J. \& Henriot, P. (1981) Religious Private Voluntary Organisations and the Question of Government Funding. Orbis, NY.

Seers, D. (1975) "The Meaning of Developmenr" in Wilber, C.K. (ed.) The Political Economy of Developments $\mathfrak{E}$ Underdevelopment, New York.

Tendler, J. Turning Private Voluntary Organisatins into Development Agencies: Questions for Evaluation, Report Prepared for USAID, Washington. 1982.

van der Poort, K. (1987) The Development Market: A Study on Government Funding of Church-Related Development Cooperation. WCC, Office of Resource Sharing, Geneva. 


\section{Contextualizing History}





\section{Learning from History: Religion, Politics, and the Problem of}

Contextualization - the Case of J.W. Colenso Jeff Guy

John William Colenso, the first Bishop of Natal, remains a significant figure in South African history, and of particular interest to us here, for he was one of the first figures in South African history to accept the interconnectedness of religion and politics, and see his fight for freedom in both religion and politics as a unified struggle. He was born in England in 1814. His intelligence and scholarly talent took him from a modest background to the centre of intellectual and religious privilege when he won a scholarship to Cambridge. There he excelled academically, eventually taking holy orders in 1839 . While a parish priest he wrote a series of widely used mathematical text books and in his fortieth year was sufficiently secure financially to accept the offer to be bishop of the new diocese of Natal. Here he threw himself into an ambitious scheme for African education and advancement, making a particular contribution to the translation of the Bible into Zulu. However, his direct experience of missionary practice, including his intimate discussions with Africans, led him to the conclusion that contemporary missionary practice was fundamentally flawed. His dissatisfaction became focussed on the inadequacy of contemporary attitudes to the Old Testament, in particular its literal interpretation as the Word of God. However, his published biblical criticism was made useless by the religious and intellectual establishment in Britain. Colenso was deprived of funds and attacked by the Church which drove him into isolation and forced him to spend years in increasing financial difficulty and acrimonious dispute.

Then, in the depth of his isolation in Natal, the stirring of aggressive colonialism and then British imperialism in the 1870 's, convinced 
Colenso that he must protest against the injustices being perpetrated against African society. The record of Colenso's defence of Langalibalele of the Hlubi, and then the Zulu royal house, is outstanding. But, for all his courage, intelligence, and the energy he expended in the pursuit of justice his efforts came to nothing as the people in whose cause he worked were conquered and their independence taken from them. Colenso died in 1883, his struggle for justice defeated, alone, and ridiculed by his white contemporaries.'

\section{THE HISTORIAN'S TASK}

What are we to make of this life? - a life so deeply involved both in religion and politics and South Africa, and in turn, what can it tell us about religion and politics in South Africa today? First of all let me say that an assessment has to begin by being historical. Without this historical perspective any attempt to assess the man becomes impossible: either the assessor's perspective distorts the subject, or the sources dominate, and the totality of the life is fragmented.

We can start with the most obvious point. The prejudice of Colenso's contemporaries against his biblical criticism was so intense that it has profoundly affected the evidence we have of his life. This distortion has continued to this day and it is easy to give examples of highly reputable scholars, depending on secondary assessments, who parrot nineteenth century prejudices as historical truth. ${ }^{2}$

It is one of the historian's tasks simply to try and put the record straight.

\section{THE NECESSITY OF INTEGRATION}

Another problem is created by the sheer range of Colenso activities and interests - any complete study would have to move into so many fields in order to make a full assessment: theology, biblical criticism, history, victorian social and scientific thought, mathematics and mathematical pedagogics, African languages, ecclesiastical law, colonial law, Zulu history, the history of imperialism.

The general tendency has therefore been to specialise on one aspect of his life, and in so doing the totality of it is lost. This tendency has increased in recent years when interest has begun to concentrate on the 
final decade of Colenso's life, when he became involved in direct agitation on the side of Africans against colonial and imperial policies. This has led to the elevation of Colenso as the political activist, but the denigration of Colenso as biblical critic, and the rejection of Colenso as a religious thinker.

\section{CONTEXTUALISING THE PAST}

All these tendencies have to lead to the fragmentation of the man's life. Historical contextualization is needed if it is to be brought together. Not only must the aspects of the man's life and works be integrated but the life must be integrated with the times in which he lived.

What then is the context? This of course depends on one's particular standpoint. For me it is the context of class and colonization, industrialization and imperialism. In a sense the chronology of Colenso's life mirrored that of Britain's economic and intellectual development. $\mathrm{He}$ was born at the end of the Napoleonic wars. He grew up with the development of industrial capitalism in Britain. He experienced the stress associated with democratic political reform, the great economic and social crisis of the "hungry forties", the intellectual crisis as the British middle-class tried to come to terms with the changes wrought by industrialization, technological and scientific advance, and popular radicalism. He reached maturity with Britain's economy: the Great Exhibition of 1851 - usually identified with the height of British industrial capitalism - bisected his life. And then he joined the great movement of men, money and ideas which set out to conquer the world and which was to reach its climax in the era of imperialism at the end of the century. It was these forces which defined his life and shaped his theology and religious practice.

A context such as this provides a framework within which we can begin to situate what we know of Colenso's life. It enables us to link the social crisis of the 1830's with his spiritual crisis at this time and his acceptance of Maurician religious humanism, which provided the foundations for his interest in missionary endeavour, his critique of conventional missionary practice, his biblical criticism as the basis for effective religious teaching for the times, and to connect all these religious concerns with his later political interventions. More than this historical conrextualization enables us to escape some of the misjudg- 
ments and to suggest more plausible explanations of the man and his work.

To take examples from the two great issues which he confronted-effective religious teaching, and the treatment of Africans by the British in Natal and Zululand.

\section{THE BIBLICAL CRITIQUE}

It has always been difficult for me to understand the ferocity of the attack on Colenso as a biblical critic. Nothing I have read in Colenso's biblical criticisms is sufficient to explain the degree of violence in the attacks made upon him - attacks which destroyed his mission, and reach out of the past into the present where they continue to distort the work of historians. Colenso's words themselves do not offer an explanation - but the context perhaps does.

His biblical criticism was first published in the 1860's - a time of intellectual ferment. A major characteristic of the times was the new sense of history which was becoming apparent. Men and women had been brought up to believe in a historically bounded world - created if not some 6 or 7,000 years before, then at least at a fixed point in imaginable time. But evidence was beginning to mount which pointed to a different concept of history: a history which escaped these tight temporal boundaries. There was the geological record and the fossil record, which Lyell (a profound influence on Colenso) had publicized. There were the problems being raised with the greater knowledge of contemporary alien cultures, and also by the archaeological record which suggested a pre-historical history in Europe itself. And there was the theory of evolution as propounded by Darwin. All this questioned the accepted foundations, not only of history but the concept of time and humanity itself. Long-accepted secure intellectual boundaries were disappearing, not only in time and space, but between the human and the animal world, and with them man's relations with the divine.

Colenso's religious thinking, rooted in the universal presence of God in Man, offered him protection from these revolutionary ideas - indeed the foundations of his religious thought had been developed within this context in order to provide such protection. New insights, new discoveries, did not threaten his beliefs, rather they provoked his imagina- 
tion and awe further as he contemplated this newly-revealed evidence of God at work amongst mankind. But for many, their faith rooted in myths and unscientific dogma, these new insights created skepticism. It was people such as these that Colenso attempted to reach in his writing.

But in others this breaking down of old truths created fear and insecurity. And they attacked the ideas and those who propagated them. And Colenso caught the full force of their attacks which eventually destroyed his mission.

But even this is an insufficient explanation for the intensity of the opposition Colenso provoked. It seems to me that he also touched on extremely sensitive issues of class and race. He attacked the belief in the Bible as the literal "Word of God". But in so doing he attacked more than the Bible. He attacked what it stood for in victorian Britain. And it stood for authority: of the father in the home, the magistrate on the bench, the bishop in the pulpit, where the Bible was raised as the symbol of authority in the demand for obedience to that authority. Biblical criticism had a profound social content which has never been recognised adequately by historians and which has to be if we are to understand the religious history of the nineteenth century.

And more than this - who, according to Colenso's own account — had led him to his critique? A black man, an African ... and this in an age of expansion which was soon to give way to imperialism, social evolutionism, and a period of extreme racism and racial violence, which emphasized the civilizing role of Europe and its religion. Colenso's anecdote of how careful attention to the opinions of an illiterate African had led him to examine the foundations of his own religious thinking - the thinking of an ordained Bishop in the Church of England - was unacceptable in an era of imperialist expansion. I suspect that behind the attack on Colenso's biblical criticism lay not only questions of class but questions of race. To my way of thinking these also have to be included in any assessment of his life and work. ${ }^{3}$

\section{FREEDOM IN PERSPECTIVE}

Let us look at another failure to contextualize. In recent years there has been a strong tendency to incorporate Colenso into the ranks of the brave men and women from within the Anglican church who have 
resisted racism and injustice in South Africa. A well-known South African historian, an Anglican, for example, while warning any reader unversed in theological argument against Colenso's religious thinking, praised Colenso as "a great tribune of African freedom". 4

Here we see the danger not only of fragmenting Colenso's life but of failing to contextualize and thereby applying the standpoint of a twentieth century South African liberal upon a nineteenth century imperialist. Because Colenso was not a tribune of African freedom. Colenso did not want African freedom. He wanted British freedom for Africans. It was his explicit goal as a missionary to transform African life, to bring it the benefits of British rule, the English church, British justice, British freedom.

When he went to Africa, Colenso believed that this transformation could be brought about by making contact as a human being with the humanity of others, through education, through example, through hard work. He lived too long in South Africa, and before he died he saw the reality of the forces which actually transform lives in a colonial context - duplicity, dishonesty, and violence. He protested courageously against these means, but not the ends.

His political thinking, like his religious thinking, if his attackers had only known it, was conservative. He embarked on biblical criticism in order to regain religious authority at a time when conventional theology was being threatened by scientific discovery. In his political work he never mounted an attack on imperialism but on imperialists, - for personal dishonesty, for the pursuit of individual power, for not working within the true spirit of their calling as he saw it - to change the world in the image of European democracy, justice and freedom.

Colenso then was an imperialist - but the point of course was that he was not just this. He tested the boundaries imposed by the context in which he worked. Why? How was he able to do this? I can give no final answer to such questions of individual personality and individual psychology. But I would suggest that part of the answer at least lies in the fact that he himself crossed class boundaries in his own life as he moved from poverty to power and authority, and that this unusual experience created an unusual man, with the capacity and confidence to challenge, if not to cross, intellectual and moral boundaries as well.

And in so doing he left us a great example. Of integrity, of hard work, of courage and conviction, in the fight against racial tyranny. He 
was a pioneer in this. He lost his own fight, but he left an example for others to follow, And this of course they have done, although the victory has still to be won.

\section{SEEING THE PRESENT AS HISTORY}

However our study of Colenso's life shows that he was not able to move out of history, to move beyond the boundaries set by his own times. We, a hundred years later, can do this - indeed this is what the word contextualize implies.

But the question is - can we do it for our own times? Or are we as caught in our contemporary contexts as he was in his? I, of course, cannot answer this question finally and for everyone-although let us hope it will come up again during the proceedings of this conference.

However, any attempt at an answer must make use of the three themes of this paper.

It must consider the question of history. I have used the historical example of Colenso, not only to remind us of a great man, but also to show the limitations that the inability to see the present as history, to contextualize, imposes on even the most selfless, talented and courageous. I have tried to show that in order to escape such limitations it is necessary to situate personal experience in the broader social context. And this includes the contextualization of religious thought itself.

This is a difficult thing to do. By definition religious experience is unworldly, supernatural, and deeply felt. To contextualize religious experience, is to drag that which is intensely intimate and spiritual into the public and material world. It is difficult to make this move without doing violence to deep feelings. I know that in this paper today I have moved far too easily from theology to class, from the Bible to power. For religious experience is not just a reflection of the material world. Nonetheless, the world mediates spirituality and spirituality mediates the material world, and if I have done violence to religious feeling in my attempts to contextualize one man's religious life, it is because I feel that the balance often swings too far in the other direction. Religious feelings and actions are too often seen in their own terms.

Part of the context is political. And it is an important part because when religious emotions are widely and deeply felt and shared they 
contribute to the political context, and can be a force within it. And politics raise questions of class which in turn relate to power and the distribution of power. Once again, I am not saying that religion is a mere reflection of class forces. But what I am saying is that to understand religion and religious feeling and religious activity the class context must be taken into account.

Religion and politics intertwine and intervene and influence one another. History shows how they have done this. But these forces also, of course, apply in the present-to our own experience, which we cannot view from the perspective of one hundred years on. But we do have the examples from the past. And I firmly believe that it is the task of the historian to recreate the past as an example for the present.

What material, political, issues are at work on our religious thought today - what is the material and the political and the class basis of the wide front being created between Marxist revolutionary and spiritual activist? How is it that the adherents of a materialist philosophy which sees religion as a human response to inhuman conditions, and demands the eradication of those conditions and with it religious belief - how is it that they can work with those who situate the foundations of religious belief beyond the material world? What basis for co-operation will they have when racial tyranny is overthrown-how will they confront the economic tyranny of the times in which we live and which lays waste to the world's physical and human resources and will certainly strive to continue to lay waste to the physical and human resources of South Africa?

These aren't just intellectual questions. They are questions which have to be answered if we are to control our lives and the lives of those to come, questions which have to be answered if we are to try and escape the grip of the present - which as I tried to show in the case of Colenso can blind the best of men to crucial aspects of reality. The challenge is to take the past and see if, and how, history can be used in the present, to use history to make history - to link religion, history and politics in our thinking, and also in our actions - as Colenso did but, because we have his example in mind, with greater success. 


\section{NOTES}

1. This paper is based on my book The Heretic. A Study of the Life of John William Colenso (1818-1883), University of Natal Press, Pietermaritzburg, and Ravan Press, Braamfontein, 1983.

2. Guy, The Heretic, p. 174.

3. Since writing The Heretic I have found significant confirmation for my argument that Colenso's identification of the central issue of the times as the need to place contemporary religious teaching on a sounder intellectual footing was neither slight nor insignificant (as his critics have it) in Terry Eagleton, Literary Theory. An Introduction (Basil Blackwell 1983). Eagleton's argument in this book also supports my argument, made in more concrete terms, that the reason why Colenso met with such aggression, was not that his thinking was shallow, but that it effectively challenged religious ideas at the time, which were themselves impartant features of the ideology of the ruling class.

4. Guy, The Heretic, p. 353. 


\section{Catholics and Protestants in a Clash of Interests in Southern Mozambique}

Alf Helgesson

In the early 1880s, the southern part of Mozambique (South of the River Save) became the target of independent Protestant missionary initiatives directly from or via South Africa. The conscientious involvement of African missionaries in these ventures was notable. I refer particularly to Yosefa Mhalamhala, a Tsonga Christian from Northern Transvaal, who initiated the Mozambican mission of the Swiss Presbyterians, and the Mozambican returnee Robert Mashaba, who became the representative in Lourenqo Marques, now Maputo, of the Wesleyan Methodist Church of South Africa. ${ }^{2}$ Simultaneously, the missionaries of the American Board of Commissioners of Foreign Missions, located in Natal, obtained permission from King Muzila to start mission work at his court in the interior of Mozambique. ${ }^{3}$ For some reason, however, they settled on the coast at Inhambane, about 500 kilometres northeast of Lourenqo Marques.

These new ventures ushered in a new and involved phase in the Christian history of Mozambique. There are certain issues in the emerging clash of interests between Catholics and Protestants - more particularly in the region of Inhambane from 1880 to 1895 - which I want to explore in this paper.'

\section{CATHOLIC LETHARGY AND PROTESTANT PERSEVERANCE}

The introduction of Protestantism into Southern Mozambique certainly did not pass unnoticed. Initially, the Catholic priest at Inhambane, for instance, strongly opposed the entry of the American Board missionaries, and the Governor there issued the verdict: "I prohibit you from establishing the mission for which you begged permission. ${ }^{4}$ How- 
ever, it is quite clear that those missionaries, W.C. Wilcox and Erwin Richards, were not prepared to take "No" for an answer.

Not being able to obtain formal permission, they realized that their only possibility to establish themselves in the region was to apply for a tract of land, where they would be able to teach their "servants". And now the missionaries' insistence was rewarded. A grant of land was officially recognized in 1884.

The impact of the Protestant work, particularly the school and, a little later, printing activities, soon made itself felt among the coastal Tonga people west of the Inhambane Bay, although the religious response was slow in coming. ${ }^{5}$ It did not take long before the missionaries ventured outside the boundaries of their property, first exploring and soon preaching to people around the Bay.

There is no evidence that the American Board missionaries met with any resistance whatsoever in these activities, on the part of the Governor or the Catholic priest in Inhambane, although they were constantly expecting such interference. "The Governor", said Richards, "is very kind to us, and I think will consider our trade and our influence with the Natives and will give us a great freedom as his legal ability will allow." There is on record in 1887 one request by the local priest to the Bishop of Mozambique for advice "as to how to proceed" against the "mission of the innovators", to make their "heretic doctrines lose their attraction". But there is no tone of urgency in the letter. ${ }^{7}$

The Catholic church at Inhambane seemed to have suffered from neglect for several years. At the time of the arrival of the Protestant missionaries, the local church building had been left abandoned without roof for five years. The congregation gathered for mass in a rented building which formerly had been used as a brothel.' Through supportive action by the local Portuguese population, a reconstruction of the original church was undertaken.

Against the local priest, who had evidently been at Inhambane at least since 1882, there was continuous criticism from offical quarters. After having initially shown opposition against the coming of the Protestant missionaries, the priest may possibly have been rather satisfied that the Protestant influence was on the side of the Bay which he never had to touch. He appears to have understood his mandate not to be a missionary, but to be the parish priest for Portuguese people in the town of Inhambane. One of his bishops had some harsh words to say 
about him even in that capacity: "He occupies himself but little with the duties of his sacred ministry. He neither preaches nor teaches. . . If he wished to work, it would be of utmost importance to create in that area a mission, not only to civilize the people and to teach them the Christian Faith, but to combat the Protestant propaganda, which is established in that region. .."9

Thus, there seems to have been a fairly wide scope for the development of the Protestant mission work in the region, as long as it did not openly interfere with the work of the parish priest. This is clearly indicated by the fact that, around the middle of 1889 , there were no less than fourteen American Protestant missionaries busy at work at five different points, west of Inhambane Bay.

This development had, for most missionaries, meant a move away from the original land grant on the coast, and we may remember that, in the beginning of the 1880 s, the Portuguese hold on the "Province of Mozambique" was rather precarious. On the whole, it amounted to a few coastal settlements, of which the Inhambane town and surroundings were one of the largest. All the interior of present Mozambique - with the exception of some fortified farms ("prazos") along the Zambezi river-was under the dominion of various African rulers, of whom the most wellknown and perhaps most feared was King Muzila. His Gaza Kingdom was based upon Zulu strategy and martial technique, and a vast number of chiefs regarded Muzila - and not the Portuguese - as their supreme Ruler.

In the neighbourhood of Inhambane, Portuguese officials seldom ventured farther inland then about 20 kilometres from the Inhambane Bay. Once west of the Inhanombe river, they were in the border area between the Portuguese "Crown Lands" and Muzila's kingdom, where others, e.g. Protestant missionaries, might feel outside the restrictive Portuguese presence, Thus it comes as no great surprise that some American Board missionaries had soon spread out from their original station on Inhambane Bay, creating new centres about 25 kilometres west, trusting local chiefs for land. Although continuously living with a sense of insecurity, they soon began to make an impact on the Tshwa people in the interior, particularly on those young men who were hired as plantation workers on the mission farms. The missionaries' ambitious attempts to learn and to use the indigenous languages, even to the extent of reducing them to writing, probably helped to make them 
readily acceptable in the African villages. As time went by without any noticeable disturbance either on the part of Muzila's people or of Portuguese officials or Catholics, regular preaching visits to surrouding villages became an accepted pattern

\section{GREY DAWN AFTER DARK NIGHT}

The situation of the Catholic Church at Inhambane - and for that matter in the whole of the Mozambique Province - thus proved to be rather bleak in the early 1880s. Actually, hardly any missionary work had been done in all Mozambique for the previous 50 years. All Catholic Orders, of which the Dominicans were the strongest at the time, had been banned in 1834, and one mission after the other had been bereft of its workers. Five years later, all the interior of the Province seemed completely lost to the Church. Only a few parishes on the coast were still manned, by secular priests, most of them being Indians from the Portuguese colony of Goa. In 1855, only four priests remained in the whole Province, some church buildings were being remodeled for secular use, and others were left to be reclaimed by bush and jungle. Church records were burnt, divine services were allowed to lapse because of the lack of public interest, and, evidently, because of priests being busy in other directions. ${ }^{10}$

In the early 1880 s, official dissatisfaction turned especially against the Indian priests, In spite of their few numbers for many years, they were to a large extent blamed for the decadence of the Church. Possibly, the fact that Indians from Goa had, for many years, been among the strongest prazeiros (= farmers) in the Zambezi region who, at times, created administrative headaches for the Mozambique authorities, can have added to official spitefulness against Indians.

However, although religious orders were still officially banned until the very end of the 19th century, a new development was discerned in the beginning of the 1880s. A report from Inhambane that two foreign missionaries - Catholics - were on their way to Muzila's capital caused the Governor General, Agosto Sarmento, to make the following confidential remark: "I'm going to give certain instructions to that official so that he does not lose those individuals out of sight." "Although little further is heard of those missionaries, it is important to note that they were foreign Catholic missionaries, belonging to some Order, and both 
these facts caused some wariness in official quarters. ${ }^{12}$ A strange ambiguity: Catholicism was the official religon, but Catholic missionary efforts were suspect!

Very soon another group of foreign missionaries was sighted, this time four French priests in the area of Quelimane, and, to make things even worse, they were Jesuits whose Order had been banned from all Portuguese territories for 120 years! Still, the official report about them to the Lisbon Ministry sounds a cautious note of acceptance: "One of them has already given religious relief, and the people are satisfied with him. They have not presented themselves to the authorities of the district. As it is possible that more will arrive, I humbly ask Your Excellency for precise instructions."13

Although there were a few Catholic missionaries beside the parish priests in the Province of Mozambique when the first Protestants started their work, it is interesting to note that they were all active in completely different parts of the territory. Probably for geographical reasons, having started out either from Natal or the Transvaal, the Protestants aimed at the Southern half of the Province, while the Catholic missionaries focused their attention on the Zambezi region. This division might also indicate that, for the Portuguese and even for foreign Catholics, the historically important regions still presented the greatest challenge, while the Protestants, being familiar with the developing situation in South Africa, had begun to discern the potentially greater importance of the Southern area. Incidentally, this meant that there were no direct clashes between missionaries of the different churches.

\section{INTERACTIONS WITH THE KING}

King Muzila had agreed to be a vassal of the King of Portugal as early as 1861 , there had been few indications during his lifetime of his regarding this allegiance a serious matter. After his death in 1884, however, the Mozambican authorities were quick to take the necessary steps for establishing a firmer vassalage relationship. The new king, Nghunghunyana, was persuaded to let two delegates go to Lisbon to be received by the king of Portugal, and on November 19, 1885, the terms of vassalage were agreed upon. Part of the agreement was that there should be a Portuguese "Resident" at Nghunghunyana's court, and in June 1886 the Portuguese flag was hoisted and José Casaleiro d'Alegria 
Rodrigues was installed as the first "Chief Resident", "to advise the King on how to administer the country, and on potential questions concerning the King's people and Portuguese subjects". ${ }^{14}$

Two years later, the American Board missionaries finally decided to take advantage of Muzila's promise in 1881 for them to start mission work in his kingdom. The young missionaries George Wilder and Frances Bates were sent by their colleagues in Natal (!) to approach the new king. As they were heading towards Nghunghunyana's capital, in August 1888, the Portuguese Resident had long been informed, through mail-runners, of their coming. On June 30, 1888, he reported to the Governor General of Mozambique:

Two American missionaries are now in Sofala, on their way to this place, where they seem to desire to settle. It is not to be believed that the said missionaries have in mind to educate these people. It is my conviction that they are sent by the English or some other government and that their aim, purely and simply, is to belittle us in the eyes of Chief Nghunghunyana. . .

... Now, such foreigners come as ministers of religion, wanting to reside here, under the cloak of the most refined hypocrisy, in order to prepare the ground for our disparagement. I shall use all means at my disposal so that Chief Nghunghunyana won't let these missionaries establish themselves in the Gaza territory. ${ }^{15}$

King Nghunghunyana may have had other reasons for refusing to give the American Board missionaries the requested permission, when they finally arrived at his court on September 21. But it would appear most probable that the words of advice from the Portuguese Resident during the several preceding weeks had a decisive effect. This action may also be an indication of the increased awareness among Portuguese officials in the Province of what was termed "the Protestant Propaganda". No Catholic missionary was ever installed at the court of Nghunghunyana, but the Resident had a school organized, intended for the royal children and those of the court elders. Although it appears to have been difficult to keep this school regular, it was used as the main official argument at that time to hinder any Protestant work at the Gaza court. "You have come too late. I cannot have two sets of teachers." 16

It is very illuminating to compare this failure with what happened at the Gaza capital in 1893, as the Swiss Presbyterian medical missionary Georges Liengme was allowed to settle as missionary and personal medical attendant to king Nghunghunyana. Many different moves had gone before that happy moment, and one Portuguese Resident had 
succeeded for some time to stop Dr. Liengme. However, a new Resident was appointed, bringing with him from Lourenço Marques his African servant, who happened to be the local lay leader of Presbyterian work in that city.

The Swiss missionary was, therefore, introduced both to the Resident and to the King by a well-trusted African man. Added to this was the presence of an itinerant African trader, on whom the King depended for important deliveries, a Christian man in good standing within the Presbyterian mission. No wonder that the outcome was totally different from the dismal failure in $1888 !^{17}$

Local issues in Mozambique, of course, reflect emerging tensions on the international scene. Thus we have to widen the horizon of our account.

\section{LIBERALISM, PATRIOTISM AND BERLIN}

During the 19th century, the Roman Catholic Church in Portugal was under fire. With the winds of liberalism, blowing particularly from the British Isles and being largely embraced by the upper sector of Portuguese society, there also came a wave of anticlericalism. During King Pedro's struggle, in the 1830 's, for a constitutional monarchy, the Church leaders were regularly found on the side of royal absolutism, and when King Pedro won his victory in 1834, he immediately turned against the Church. Probably believing that the wealth of the various Religious Orders would give him the god-send he needed to clear up his and Portugal's embarrassed finances, he swiftly decreed all Religious Orders to be outlawed and their possessions confiscated. For the Church, this was an almost fatal blow, in particular for its mission work in the Overseas Provinces, as we have already noted.

Although the disastrous financial situation continued to be the main political headache, there were a few attempts during the following decades to improve the situation for the Church and its mission. But almost all of them were stopped by the "liberalism and free-masonry" that prevailed as popular groundnotes in decision-makers' thinking. Only about forty years later did plans begin to be formulated in earnest for new ventures.

In 1880, a Commission "for the founding of new missions in our Province of Mozambique, on one hand, and in Angola, on the other" 
was formed in Lisbon. The plans also included "an ample colonial seminary in the old convent at Chelas" (Portugal), and French Religious Orders were asked to supply teachers." The Decree of December 3, 1884, approved the statutes of the new "College for Overseas Missions" at Chelas, and a few years later, graduates from Chelas began to appear in Mozambique. Thus, in 1887, "the total number of missionaries. . . including 6 Jesuits. . . had risen to 16". 19

Nevertheless, the real awakening of the people of Portugal to the assets and problems of its overseas provinces, and, as a consequence, the need for mission work, came through international events. The Berlin Congress 1884-85 opened up new vistas, and new areas of responsibility. Its demand for "effective occupation" gave the impetus to new politics concerning the Mozambique interior, particularly in relation to the Gaza kingdom. It also fired new imperial dreams, issuing in the "rose-coloured map" in 1886, which publicized Portugal's claim to a wide corridor across Africa, linking Mozambique to Angola.

But the all-important result of the Berlin Congress for the Church was the strong emphasis on religious freedom and complete openness to the establishment of any type of religious mission in Africa. This regulation, repeated by the Brussels Conference on Slavery in 1889 , actually became a cornerstone of Protestant mission work in Portuguese Overseas Provinces. Over and over again, after the year 1885, Portuguese officials referred to this part of the Berlin agreement, indicating, however reluctantly, that the right of Protestant missionaries to be working in the Province was inviolable (as long as they were teaching religion).

\section{HEADING TOWARDS CONFRONTATION}

Even as foreign Protestant missionaries had to be tolerated within the Province of Mozambique, there was no love lost between them and the representatives of the Catholic Church. Examples abound, from both sides, of spiteful, sarcastic remarks concerning the counterparts in the opposite fold. Two examples will be given, from the Protestant side, to indicate the spirit of the relations between Protestants and Catholics:

In the case of the Portuguese, very few of them take any stock in the pious humbug carried on in the Roman churches... If a salvation revivai were to break out in Portugal, and the people were to throw off the yoke of superstition and 
priestcraft, it would be the beginning of better days for the country. ${ }^{20}$ . the Church of Rome, which is justly characterized as a most conspicuous obstacle to the progress of Christian missions... Anything in the way of friendly appeal or Christian remonstrance would be a waste of time and labor. Among the "many adversaries" Rome is as much to be encountered as Mohammedanism, or Brahminism, or Buddhism, or any other system which exalts itself against the knowledge of God. ${ }^{21}$

Perhaps the extremely strong, and often harsh, feelings on both sides meant a sharpening of the tools. It stands out very clearly that there was nothing that could match the Protestant presence in Mozambique in its power to stimulate action on the part of the Catholic Church. The Catholics knew they had an adversary, which was sometimes referred to as "clever, hardworking, sparing neither material resources nor personal strength". But the Protestant missionary spread a false religion and could never be trusted, as he "would naturally prefer the Province of Mozambique to pass to some Protestant Power, England or Germany", and, consequently, he would, by his mere presence, strongly denationalize "the Natives". 22

Recognizing, however, after 1885, that Protestant missionaries were there to stay, the Catholic authorities in the Province of Mozambique became increasingly more aware of the necessity to make strong and swift countermoves against the "Protestant propaganda". The first church leader explicitly to recognize this need, was the third Mozambique bishop during the 80 's, once more with the name of António. In the beginning of 1888, he wrote to the Lisbon Minister of Navy and Overseas Affairs:

... I would like Your Excellency to feel the great necessity to establish new missions at other points, especially at Lourenço Marques and Inhambane. For this purpose, lacking other personnel resources, we could take hold of the /Jesuit/ padres in the Zambezi region. But it would be necessary to give them all possible assistance...

In Lourenço Marques we need to combat the Protestant propaganda, which lately has established a school in that city... Even the Governor recommends in his report. . the establishment of a mission.

At Inhambane, we also have to combat the Protestant American Mission, which spares no pains in order to call the blacks/into their fold/. . ${ }^{23}$

Two years later, the first proper Catholic mission in Southern Mozambique, since the 17th century, was established some 10 kilometres west of Inhambane Bay. An official Portaria (= Bay-law) of May 5, 1890, 
created "the Mission of St. Joseph of Nhamussua at Bembe". The French Jesuit missionary at Tete, Fr. Victor José Courtois, was charged with the difficult task of beginning mission work in that region, and he is said to have learned to speak the local Bitonga language. A school was started, but the missionaries encountered great difficulties. Two years later, padre Courtois complained:

In the beginning of my work here, it was always difficult to get started with the important work of primary instruction of children in the neighbourhood, because the blacks lived in a deplorable apathy towards all kinds of teaching. They were also full of futile preconceptions, e.g.: After having been to school at the Mission and learnt a few of the letters, the pupils would be taken to Mozambique Island by the Government in order to be enlisted as soldiers. Fortunately, these frights and preconceptions are disappearing, and some children have now taken the first steps. . . ${ }^{24}$

Even as the Bembe Mission was being established, other missions were called for. Bishop António Barroso had not even arrived in Mozambique before he, in 1891, loudly called for "three Civilizing Catholic Missions in the District of Lourenço Marques, to counter-balance the influence of the Protestants who are there".

The same arguments once more came to the fore: "A long experience has shown us that the Protestant missionary of any nationality or denomination is against not only the religion of the State but also the political rights of the Portuguese Crown." 25

Not only church leaders now saw the great need for efficient Catholic missions in the Province. In a letter from a Governor General in 1892, this official expresses his almost desperate feeling of extreme urgency as he faces the great lack of missions in Mozambique:

I believe, Your Excellency, that it is an absolute and pressing necessity to take care of Catholic missions in this Colony. The Protestant mission that is established here has as its head a clever and hard working padre, who makes an excellent propaganda and works incessantly, day and night, in his ministry. Our padres, who unfortunately are no great workers, have no idea of how to penetrate the soul of the blacks. Thus they do not only fail to counter-balance the steadily growing current of Protestantism, but they even depreciate and abandon the few remains of Catholicism which still exist here. ${ }^{26}$

Inevitably, such strong sentiments on both sides of the issue were bound to result in clashes. The strange fact, however, is that such clashes were few and far between. They came out in daily frustration as well as in 


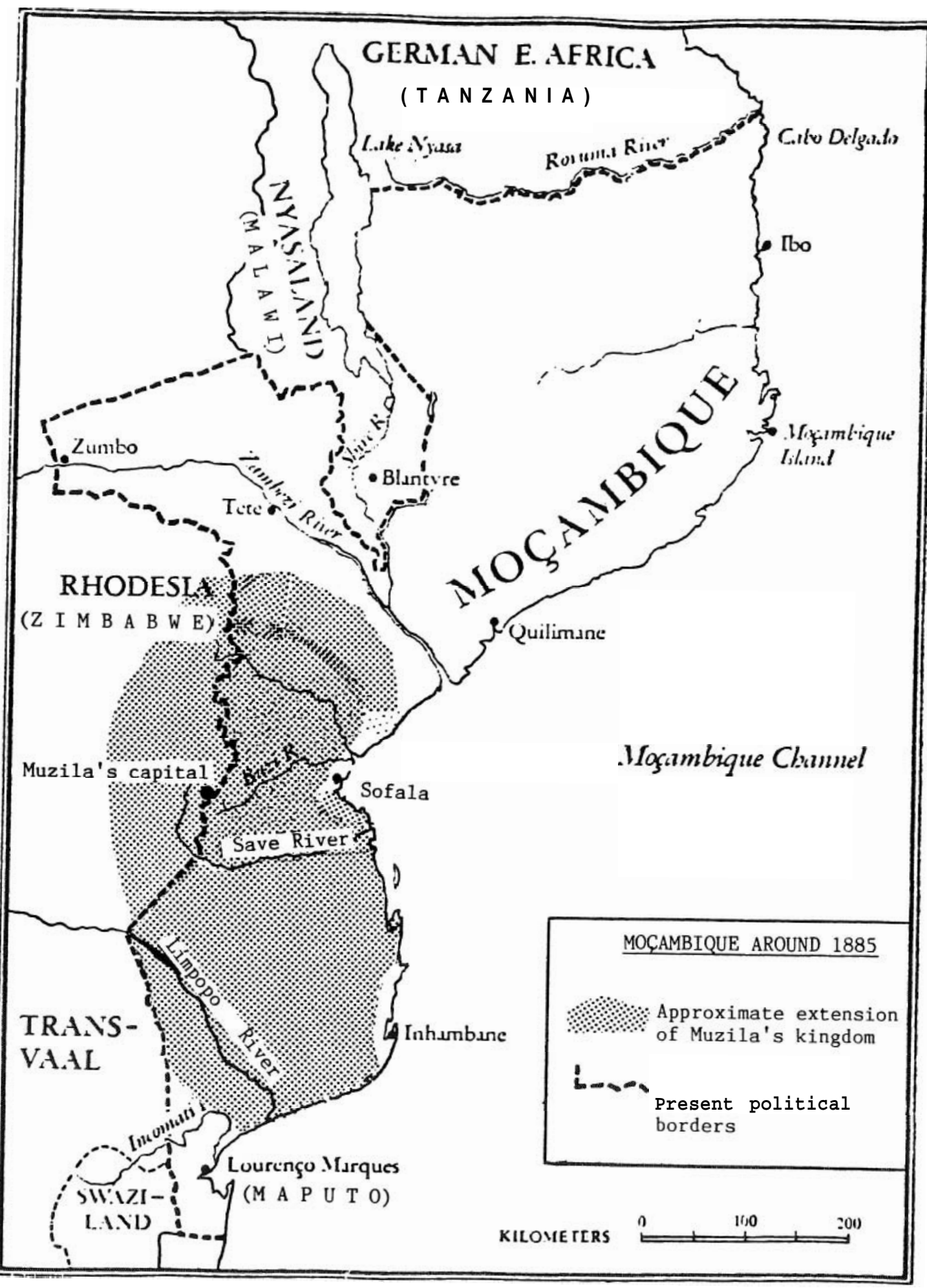


hundreds of internal reports rather than in open confrontation between representatives of the two fighting groups. As time went on, there were several attempts at hindering the expansion of the Protestant work by establishing laws, e.g. about the use of the Portuguese language in schools.

Summarizing very briefly this survey, I venture the following assessment: From the Protestant side, the issues on confrontation were religious and moral and sometimes economic. While religious elements were very important also from the Portuguese Catholic side, it appears, however, that the main issue was a secular one, namely the question of de-nationalization. Perhaps this was to be expected in a church so closely but precariously linked to the state in a small and poor nation, which was struggling to keep its historical pride of a vast empire, in the face of emerging imperial giants on all sides.

\section{NOTES}

1. This is an abbreviated version of the paper "Catholics and Protestants in Southern Mozambique during the last Quarter of the Nineteenth Century", presented at the Conference on "Religion and Politics in Southern Africa" and published in the 1989 Annual Report of Uppsala Studies of Mission.

2. van Butselaar, Jan, Africaim, Missionaries et Colonialistes, Leiden 1984, 32 and 49 ss.

3. King Muzila, the mighty leader of the Gaza kingdom was son of Soshangane, who with his Zulu followers had deserted the Zulu king Shaka in the tremendous confusion called Mfecane. In English literature, he is generally referred to as Umzila, the proper Zulu form of his name. In Mozambique, however, he is usually called Muzila, in accordance with the common prefix for persons in the local languages.

At this time the Gaza kingdom had for some years been an object of interest for the Government of the Natal Colony, both as a potential source of labour and as a logical direction for the further extension of British imperial influence. See Norman Etherington: "Labour Supply and the Genesis of South African Confederation in the 1870s" in Journal of African History, 20(1979), 235-253.

4. American Board of Commissioners for Foreign Missions, Archives, New York, (ABCFM), Reel 187, Means to Wilcox 1512 1883; Wilcox to Means 30171883.

5. Eight months after arriving at Inhambane, Richards made the sad observation: "There is nothing more certain than that there is nothing in our religion that interests these Natives, and the more they comprehend it, the more they do not want it" (ABCFM, Richards to Smith 612 1885).

6. Ibid. 
7. Arcebispado Maputo (Arch-Bishop's Archives), Box "Missao de Inhambane 1849-1914", Gaspar Nicolau Constantino de Sousa to Bishop of Mozambique, 251111887.

8. Arquivo Nacional Ultramarino de Lisboa (ANUL), /Gov.Geral/, Pasta 7, Cap. 3, 16171885.

9. ANUL, (Bishop António), Pasta 9, Cap. 5.7, 29/11 1887.

10. Brásio, António: D. António Barroso, Missionário, Cientista, Missidlogo, Lisbon 1961, 193-197. - As far as the Jesuits are concerned, it should be noted that they had been banned in Portugal and all its provinces as early as 1759 , as the Marques de Pombal had found the Jesuits an obstruction on his ruthless way towards dictatorship. See dos Sonatos, Eduardo: O estado português e o problema missionário, Agência Geral do Ultramar, Lisboa 1964, 9-13.

11. ANUL, Pasta 3, Cap. 1, Letter 23511881, 29141881.

12. Rev. Erwin Richards met one of those missionaries, Fr. Blanco, an Italian, at Inhambane and stated that they were going back to Natal, disappointed with their trip to Muzila's Kingdom (ABCFM, Reel 186, Richards to Means, 15/6 1881)

13. ANUL, Pasta 3, Cap. 1, Secretary of the Governor General to the Minister of the Navy and Overseas Affairs, 27151881.

14. ANUL, Pasta 8. Cap. 4, Certificado de Vassalagem, 191111885.

15. ANUL, Pasta 10, Cap. 2, Chief Resident to Gov. General, 30161888.

16. Nghunghunyana's words to the American missionaries, as quoted from Missionary Herald, American Board of Commissioners for Foreign Missions, Boston, Feb. 1889, 58.

17. v. Butselaar, op.cit., 101-106.

18. Letter from Paiva de Andrade to Padre Eduardo Durand, Paris, 2019 1880, quoted in F. Felix Lopes, op.cit., 58. Paiva de Andrade was instrumentai in getting Jesuit missionaries to go to Mozambique in 1881.

19. ANUL, Pasta, Cap. 5.7, (Prelazia) 10111887.

20. Hogue, W.T.: Harry Agnew, A Pioneer Missionary., Chicago 1905, 174-175.

21. Article in The Missionary Herald, May 1880, quoting The Church Missionary Intelligencer of the Anglican CMS.

22. Mouzinho de Albuquerque, quoted in A. Freire d'Andrade, Relatórios sobre Mozambique, Lourenço Marques, 1907, Vol. V, 301.

23. ANUL, Pasta 10, Cap. 4.8, Bishop António to Ministry, 20111888.

24. Arcebispado, Maputo, Box "Missao de Mongué, 1891-1944", Courtois to Bishop António Barroso, 18151892.

25. ANUL, Pasta 13, Cap. 6, Bishop António Barroso to the Minister of Navy and Overseas Affairs, 21/7 1891.

26. ANUL, Pasta 14, Cap. 1, Gov. Gen. Rafael Lopes de Andrade to Ministry, 251292. 


\section{Concluding Remarks}

\section{JOSÉ CHIPENDA}

We are coming to the end of a conference in which we discussed many topics but have not arrived at a particular conclusion. The job assigned to me is therefore impossible for I am supposed to introduce what should be done as a follow up.

The whole conference was concerned with South Africa and Zimbabwe. Very little attention was given to Angola, Botswana, Lesotho, Malawi, Mozambique, Namibia, Swaziland, Tanzania and Zambia. It would be good if future conferences could widen the scope of discussions. There is a reason to suspect that whatever happens in Mozambique and Namibia will equally affect other countries in the region.

The Nordic countries and very specially Sweden started long ago to participate in the struggle to liberate Southern Africa. In 1970, Sweden and Norway provided resources to set up special funds of the WCC programme to Combat Racism. Ten years afterwards, Nordic countries were instrumental in launching the Southern Africa Development Coordinating Committee (SADCC). Last year (1988), Churches in the SADCC and Nordic countries developed a covenant relationship. They first met in Norway in February and in Zimbabwe in June.

We welcome the initiative the Scandinavian Institute for African Studies and the Nordic Institute of Missionary and Ecumenical Research have taken in organizing this conference in Uppsala on Religion and Politics in Southern Africa. Unfortunately, there were too many papers but not enough time for discussions to develop a common focus.

What we gathered is that in speaking about Southern Africa:

a. there is a widespread anxiety regarding the future;

b. there is need to detect new trends; 
c. there is a desire to contribute to influence positive action; for example: an attempt was made to speak about Religion and Education and to consider the input that may come from Churches both independent and historical and Islam.

The discussion of papers presented reminded me of the workshop I attended in Saõ Paulo, Brazil, in 1980. Included among participants were liberation theologians and peasants from Latin America. During the workshop, theologians, after reading their papers, asked peasants to react. One of them volunteered to do it. He stood amidst theologians and said: "I am here in your midst like an insect surrounded by scientists. One of the eager to study the insect asked to pull out one of his legs to be inspected. Another scientist, pursuing his studies asked the permission to pull out the second leg. At the end the poor insect surrounded by the scientist became legless."

For people in South Africa, who are suffering day in day out, inside and outside the jails, it is not easy to appreciate what we have been doing here. Our research, if not embedded in reality, does not help people in trouble,

The theme of the conference was Religion and Politics in Southern Africa. In my understanding, religion is a social phenomenon. It changes with society but never disappears. Our main concern should be to look into the form of religion we will have in post-apartheid years. I would therefore end by raising some questions:

1. Will the Church in South Africa continue to be the cradle of innovators in the days to come?

2. What should be done to prevent that the churches be used by reactionary forces?

3. Is there any way of devising new education methods which will enhance the process of learning for transformation?

There is no doubt that the work we started in Uppsala ought to be continued. This ought to be done in dialogue with people in Southern Africa. They ought to be given chance to identify priorities even before we embark on research papers. It is proper that in the process we develop covenant relationship with those who suffer and give them the support required to overcome evil without bitterness. 


\section{SIGBERT AXELSON AND CARL F. HALLENCREUTZ}

In the Introduction to this volume the Uppsala seminar on Religion and Politics in Southern Africa was introduced as a multidimensional affair. Expectations of individual participants differed and certainly the assessment of proceedings too differ due to varying backgrounds, individual priorities and different roles in the continued struggle for a South Africa freed from apartheid. In this tentative conclusion an attempt will be made to share some insights from discussions which took place in the more specialized seminar groups and in plenary sessions.

\section{STRUCTURE OF SEMINAR}

As noted already in the introduction the seminar operated at three levels. Material from all three levels is presented in this volume. References have already been made to presentations at public functions by Lisbet Palme and Archbishop Desmond Tutu. The Archbishop of Cape Town also preached in an ecumenical service in Uppsala Cathedral on Sunday, June 18th.

After the opening session, where the main address was delivered by the Hon. Minister Lena Hjelm-Wallén, the seminar started with a Southern African Scenario, which placed the issues which were to be pursued further in the course of the seminar in their proper context. Billy Modise's and Tor Sellstroms papers were part of that introduction.

Continued proceedings provided opportunities for plenary sessions as well as topical discussions in specialized seminar-groups. In fact particular attention was given to providing Scandinavian - and some African — research students opportunities to tentatively discuss emerging issues in their research.

Four main themes were explored in papers and subsequent discussions in plenary sessions, namely Church-State conflicts in South Africa in light of the continued struggle for a Post-Apartheid South Africa, the historical evolution of Islam in Southern Africa, the political roles of African Independent Churches, and lessons to be learned for South African developments from the Church's participation in the Liberation of Zimbabwe. Sheena Duncan's paper provided substantial 
input to the pursuit of the first theme; Ephraim Mandivenga's eloquent survey introduced reflections on the second. He was the first to regret that his presentation could not be supplemented from within the South African context by the dynamic Maulana Farid Eshaq.

On the advice of Farid Eshaq at a previous visit to Uppsala in December 1988 one plenary session was devoted to African Independent Churches and political roles with introductory presentations by Prof. Bengt Sundkler and Prof. Matthew Schoffeleers. Bishop Patrick Mutume's and Prof. Carl F. Hallencreutz's interrelated papers highlighted issues involved in the fourth theme. Reports from the topical seminar groups provided material for the final plenary session.

In addition to the deliberations in plenary sessions, three topical seminar groups had originally been planned; the first dealing with Church History, the second focusing on Theology, and the third exploring issues within the general theme of Religion and Society. Papers were invited to be discussed within these seminar groups. Some of them such as contributions from Agnes Chepkwony Ongaro, Per Frostin, Paul Gundani and the Rev. Alf Helgesson have been amended after the seminar for inclusion in this volume.

Special resource persons were invited to introduce deliberations in these topical seminar groups. These were Jeff Guy, Matthew Schoffeleers, and Gabriel Setiloane. It was at the introduction to the seminar discussion on Church History, that Guy shared his thoughtprovoking views on Contextualizing History. Axel Ivar Berglund chaired the third seminar group and submitted his critical analysis of the remaining structural base of apartheid as background for discussions in this group.

Already in the preparatory discussion the extending role of rightwing religious movements operating from bases in America was identified as one particular issue to explore. The Rev. Ove Gustafsson's paper on the Rhema Church illustrates what is at stake. In the course of the seminar it proved to be useful to allow additional time for deliberations on related issues in a fourth seminar group. Sigbert Axelson chaired that seminar and Paul Gifford served as a special resource person in addition to local experts such as the Rev. Alex Bhiman from the Institute of Contextual Theology, Johannesburg, and the Rev. Farai Chirisa and Hartwig Liebich from the regional Ecumenical Documentation and Information Centre (EDICESA) in Harare. 
In our continued reflections we first dwell on some general issues which were highlighted in plenary discussions. We then move on to additional questions which were treated in the topical seminar groups.

\section{THE POST-APARTHEID PERSPECTIVE}

It certainly gave the seminar a special sense of urgency that issues related to Religion and Politics in Southern Africa were seen in an explicit Post-Apartheid Perspective. This perspective added a critical question when assessing on-going changes in South Africa: in how far do these really aim at a post-apartheid society? Or do they continue to be where window dressing? These issues continue to be relevant even after "the change over from P.W. to F.W." to quote Archbishop Tutu's witty summary of ongoing political changes in South Africa. Admittedly these changes have been more far-reaching than what was anticipated at the time of the seminar, although they do not as such usher in a Post-Apartheid South Africa in a more qualified sense of the term.

In certain regards, issues related to the Post-Apartheid perspective were qualified further. One concerned whether this perspective should be seen as a kind of an object of research in its own right or whether instead it provided a framework for scholarly pursuit. Representatives of ANC, and not least Bunny Mackay of SASPRO, reinforced that the Post-Apartheid Perspective should not be developed in isolation. Instead, he suggested, it demands participatory research with the people and in immediate dialogue with the democratic forces within South Africa. What this implied in the South African context was illustrated in a deeply concerned contribution by the Vice-Chancellor of the University of Western Cape, Dr Jaques Germel.

With reference to questions raised in the introductory Southern African Scenario the Post-Apartheid perspective was also seen in terms of projected developments within SADCC. Whilst there was general agreement with the overall-assessment of possible trends and necessary priorities within the region, some people voiced a certain critique of the idea of a massive Marshal1 Plan to facilitate regional developments. Instead, the redistribution of the nation's wealth within a regional context was seen as the first priority, 


\section{RELIGION IN THE POST-APARTHEID PERSPECTIVE}

African scholars - most notably Setiloane and Mandivenga-emphasised that Post-Apartheid South Africa, too, will be a multi-religious state like neighbouring nations in the region. In the case of Setiloane, this argument did not simply mean a necessary affirmation of pluralism on the institutional level. It also implied a recognition of certain basic dynamics of convergence on the level of a shared African spirituality, which is best conveyed in terms of ubuntu, i.e. humanity or humanness.

However, the way in which the role of religion in Post-Apartheid South Africa should be defined differed quite considerably. One extreme position was occupied by the Rev. Fumanekile Gquiba of the Department of Religious Affairs of ANC. He quoted the process of secularization in Eastern and Western Europe and did not rule out a similar development in Post-Apartheid South Africa. He anticipated a reduction of the numerical strenght of Christianity but reinforced the multi-religious features of a future South Africa freed from apartheid.

Others, such as Modise and Mutume, tackled the issue differently. They suggested that in order to properly project the future role of religion in South Africa it is important to make note of the interaction of religious groups with forces which struggle for Liberation now. Thus the real issue was not a matter of generalized projections but rather a prophetic concern for relevant action now.

Insights in the involvement of both churches and traditional religious institutions with the Patriotic Front in the struggle for Zimbabwe as well as experiences from continued developments after Independence were advanced in support of this view.

\section{CHURCH AND STATE IN A POST-APARTHEID PERSPECTIVE}

On the basis of these general assessments, continued discussions on projected Church-State-relations in a future South Africa freed from apartheid could be specified further. Particularly challenging proved to be Modise's plea for a shared identity and necessary participation of the Church with the Liberation Movement. The theoretical implications in this plea are both a general recognition of the basic African dimension of ubuntu and reflections on what Modise calls "a grafted Church".

Whilst the plea for participation was generally recognized the charac- 
ter and identity of the Church as a partner in the struggle for Liberation proved to be quite involved. Alluding to the invitation in the ANC:s Constitutional Guidelines to active participation in "the extensive and democratic debate" on the blueprint for an egalitarian South Africa, the issue at stake is what sort of a partner the Church is in that palaver. What about the Church's ministry as a prophetic voice and enabler of the poor and marginalized even after Liberation? In the seminar group on Religion and Society this enabling role was spelled out particularly in terms of a continued and relevant education in view of future needs in a South Africa freed from apartheid.

Bearing in mind the necessary relationship between approriate action now and continued relevance in a future South Africa, the political roles of African Independent Churches provided a lot of fireworks. Many, including the Rev. Gquiba and the Rev. Bhiman affirmed that the Independent Churches have to be duly considered on the way to and within a Post-Apartheid South Africa. The actual political roles of these churches today proved to be controversial.

In his substantial paper Schoffeleers from Amsterdam did not rule out - in general terms - that different forms of Independent Churches do perform political roles. His specific concern, however, was to illustrate how extensive groups of such churches which lay primary emphasis on healing tend to be politically acquiescent. He also gave evidence of the way in which such churches for this very reason have been co-opted by the present political administration.

The discussion on Independent Churches became very lively. The tendency was to generalize Schoffeleer's observations to include all forms of Independent Churches and question them on that basis rather than to explore further his particular insights as regards Healing Churches. Continued developments in South Africa may very well provide additional support for Prof. Schoffeleer's critique.

\section{CONTEXTUALIZING HISTORY}

As already noted, issues from plenary sessions were pursued within the specialized seminar-groups. There they were related to parallel themes which were explored on the basis of papers available to the respective groups.

The seminar group on Church History was rather small in the actual 
number of participants. At the same time, it was very rich as far as specially designed papers were concerned. In addition to Dr Guy's challenging introductory paper, no less than three additional contributions to that seminar group are included in this volume.

Relating both to Guy's explicit views on what makes up the historical context and to Chepkwony Ongaro's and Paul H. Gundani's papers on the Church's contribution to Nation-building in Zimbabwe, as well as to Mutume's and Hallencreutz's reflections in plenary presentations on lessons to be learned from developments in Zimbabwe for the Church in South Africa, this seminar ended in a most involved discussion on Church and Land. Gundani and the Rev. Chirisa summarized how their respective churches became substantial land-holders after Cecil Rhodes' annexation of what since has become Zimbabwe. They also illustrated how negotiations for a transfer of missionary farms to local communities comprising of both local tenants and squatters have been pursued with communal authorities. Chichawasha and Epworth within Greater Harare were quoted as relevant examples. Mackay underlined the need for the Church in South Africa to develop a viable policy on land holdings in view of the need for radical revision of present Land Laws in a Post-Apartheid South Africa.

\section{TOWARDS A SOUTH AFRICAN THEOLOGY OF LIBERATION}

The special seminar group on Theology started with a nearly paradigmatic encounter of different views of Black and African Theology. In his introductory address to the group Schoffeleers reinforced the distinction between Black and African Theology by illustrating the differences in socio-economic base of the respective schools of thought, Frostin on the other hand wanted to reduce the inherent differences between Black and African Theology by highlighting how they converge in their critique of traditional Western ways of doing theology. The continued seminar discussion tried to overcome a necessary counterposition of these two perspectives and identified convergence not just of Black and African Theology but also in the various ways to interpret and understand theological trends in South Africa.

This seminar group, too, was faced with the challenge of Right Wing Religious groups performing a distinct role in support of theological and 
ideological claims of the present regime in South Africa. In this regard, one issue from the general discussion in the plenary on the role of religion in a Post-Apartheid Perspective was further pursued, i.e. how to counter-act Anti-Marxist caricatures in the official propaganda of those who resist change in South Africa and how to grapple with AntiMarxist inhibitions in certain sectors of the Church which restrict their involvement in the struggle for Liberation. One way ahead in the Namibian case was convincingly proved by Frostin in his analysis of the Rev. Kameeta's Liberation Theology from within the Namibian context.

\section{RELEVANT EDUCATION IN A POST-APARTHEID PERSPECTIVE}

With Setiloane as the special resource person, the third seminar group further pursued issues related to the basic preconditions for a multireligious South Africa. As part of that agenda the group made a most useful inventory of priorities in Religious Studies with reference to the necessary requirements for a creative dialogue of religious and political institutions on the way to and after Liberation. This seminar group also explored further economic issues introduced in the Southern African Scenario from the very beginning of the seminar. In this regard a paper presented by Fr. B. Connors provided additional input.

Of special interest to report from this seminar group is the inventory made of general educational issues in view of the transformation of present South Africa to a Post Apartheid Society. The present situation proves to be very grave. To quote from the group report: "With a Black Community uneducated by Bantu Education and White flight out of the country, there will not be enough qualified people to take on production and maintenance of everyday functions and needs."

In identifying priorities for the future a relevant professional and technical training was given preference over and above advanced academic degrees in highly specialized fields. The Bush universities within the present scheme of Bantu Education were ruled out. Instead the present priorities at the University of Western Cape were highlighted as a relevant alternative with an expressed allegiance with the democratic forces. 


\section{A NEW STATE THEOLOGY}

As already noted, the rapid spread of new religious movements with a simplistic view of the Bible and elaborate healing praxis as distinct religious features and an overt or covert support for the cause of the present minority regime in South Africa emerged as an additional issue to be attended to in a special seminar group. Here, Gifford contributed insights from his pioneering study of "the Religious Right in Southern Africa" and the Rev. Gustafsson's paper provided material which illustrates distinct features of an emerging new State Theology to use the classification of the Kairos Document.

This seminar group proved to be very timely. It could contribute to the articulation of issues which were already identified and put on the agenda for a regional seminar in Harare under the auspices of EDICESA. Furthermore the Rev. Bhiman could give an imaginative contribution to the discussion by testing points which have later on been elaborated further in the ICT Document On the Read to Damascus.

\section{WHAT NEXT?}

The final plenary session received reports from the four seminar groups. The panel also included Mackay from SASPRO and José Chipenda of the All Africa Conference of Churches, who assessed the relevance of the proceedings from their respective points of view.

The session was intense. It convincingly highlighted substantial issues which had been explored during the preceding days. It also reflected differences in the assessment of the lasting relevance of the academic encounter during the seminar. Both Mackay and Chipenda defined relevance in terms of what favours the democratic forces in Church and Society in Africa. They also pleaded for "supportive research".

In the continued discussion, views were also invited on the value of a continuation of this kind of multidimensional missiological seminars with SIAS heavily involved in the planning and pursuit of the programme. Significant hints were given and the response to this volume will inform our continued discussion. 


\section{List of Contributors}

Sigbert Axelson, Associate Professor and Administrative Dean, Department of Theology, Uppsala University

Axel Ivar Berglund, Associate Professor, former Director of Theology of South

Africa Council of Churches, Johannesburg, Secretary of South Asia, Church of Sweden Mission, Uppsala

Agnes Ongaro Chepkwony, Research Fellow of Department of Theology, Uppsala University

José Chipenda, General Secretary of All-Africa Council of Churches, Nairobi

Sheena Duncan, Chairperson of Black Sash, Johannesburg

Per Frostin, Professor of Systematic Theology, University of Lund

Jeff Guy, Senior Lecturer in Department of History, University of Trondheim

Paul Gundani, Staff Development Fellow of Department of Religious Studies, Classics and Philosophy, University of Zimbabwe, Harare

Ove Gustafsson, Research Student of Department of Theology, Uppsala University Carl Fredrik Hallencreutz, Professor of Studies in Mission, Uppsala University

Alf Helgesson, Research Student of Department of Theology, Uppsala University Ephraim Mandivenga, Senior Lecturer in Department of Religious Studies, Classics and Philosophy, University of Zimbabwe, Harare

Billy Modise, Chief Representative of ANC in Sweden, Stockholm

Patrick Mutume, Executive Secretary of Zimbabwe Catholic Bishops Conference, Harare

Lisbet Palme, Chairperson of the Swedish UNESCO Committee

Mai Palmberg, Publishing Editor, the Scandinavian Institute of African Studies, Uppsala

Matthew Schoffeleers, Professor Emeritus, Free University, Amsterdam

Tor Sellstrom, Economist, SIDA Office, Harare

Bengt Sundkler, Professor Emeritus, Uppsala University

Desmond Tutu, Archbishop of the Church of the Province of South Africa, Cape Town 


\section{Seminar Proceedings}

from the Scandinavian Institute of African Studies

1. Soviet Bloc, China and Africa. Eds. Sven Hamrell and C.G. Widstrand. 173 pp. Uppsala 1964. (Out-of-print)

2. Development and Adult Education in Africa. Ed. C.G. Widstrand. 97 pp. Uppsala 1965. (Out-of-print)

3. Refugee Problems in Africa. Ed. Sven Hamrell. 123 pp. Uppsala 1967. SEK 45,-

4. The Writer in Modern Africa. Ed. Per Wastberg. 123 pp. Uppsala 1968. SEK $45,-$

5. African Boundary Problems. Ed. C.G. Widstrand. 202 pp. Uppsala 1969. SEK $60,-$

6. Cooperatives and Rural Development in East Africa. Ed. C.G. Widstrand. 271 pp. Uppsala 1970. (Out-of-print)

7. Reporting Africa. Ed. Olav Stokke. 223 pp. Uppsala 1971. SEK 70,-

8. African Cooperatives and Efficiency. Ed. C.G. Widstrand. 239 pp. Uppsala 1972. SEK 75,-

9. Land-Locked Countries of Africa. Ed. Zdenek Cervenka. 368 pp. Uppsala 1973. SEK 110,-

10. Multinational Firms in Africa. Ed. C.G. Widstrand. With an introduction by Samir Amin. 425 pp. Uppsala 1975. (Out-of-print)

11. African Refugees and the Law. Eds. Göran Melander and Peter Nobel. 98 pp. Uppsala 1978. SEK 60,-

12. Problems of Socialist Orientation in Africa. Ed. Mai Palmberg. 243 pp. Uppsala 1978. (Out-of-print)

13. Canada, Scandinavia and Southern Africa. Eds. D. Anglin, T. Shaw and C.G. Widstrand. 190 pp. Uppsala 1978. SEK 90,-

14. South-South Relations in a Changing World Order. Ed. Jerker Carlsson. 166 pp. Uppsala 1982. SEK 100,-

15. Recession in Africa. Ed. Jerker Carlsson. 203 pp. Uppsala 1983. SEK 110,-

16. Land Management and Survival. Ed. Anders Hjort. 148 pp. Uppsala 1985. SEK $100,-$

17. Religion, Development and African Identity. Ed. Kirsten Holst Petersen. 164 pp. Uppsala 1987. SEK 125,-

18. The IMF and the World Bank in Africa: Conditionality, Impact and Alternatives. Ed. Kjell J. Havnevik. 179 pp. Uppsala 1987. SEK 125,--

19. Refugees and Development in Africa. Ed. Peter Nobel. 120 pp. Uppsala 1987. SEK 120,- 
20. Criticism and Ideology. Second African Writers' Conference, Stockholm 1986. Ed. Kirsten Holst Petersen. 221 pp. Uppsala 1988. SEK 170,-

21. Cooperatives Revisited. Ed. Hans Hedlund. 224 pp. Uppsala 1988. SEK 170,-

22. Regional Cooperation in Southern Africa. A Post-Apartheid Perspective. Eds. Bertil Odén and Haroub Othman. 243 pp. Uppsala 1989. SEK 170,-

23. Small Town Africa. Studies in Rural-Urban Interaction. Ed. Jonathan Baker. 268 pp Uppsala 1990. SEK 170,--

24. Religion and Politics in Southern Africa. Eds. Carl Fredrik Hallencreutz and Mai Palmberg. Uppsala 1991. 

Sigbert Axelson

Axel Ivar Berglund

Agnes Chepkwony Ongaro

José Chipenda

Sheena Duncan

Per Frostin

Paul Gundani

Ove Gustafsson

Jeff Guy
Carl Fredrik Hallencreutz

Alf Helgesson

Ephraim Mandivenga

Billy Modise

Lisbet Palme

Matthew Schoffeleers

Tor Sellstrom

Bengt Sundkler

Desmond Tutu

These and many others took part in the seminar on Religion and Politics in Southern Africa held in June 1989. As steps are taken towards the end of apartheid and a new political future in South Africa the theme is both topical and urgent. Religion plays and will play a large part in South Africa and the rest of southern Africa, as the experiences of Zimbabwe, Mozambique, and Namibia already show.

The participants offered both sceptical, self-critical, hopeful and cautious perspectives from a variety of viewpoints: those of churchmen, scholars, activists, concerned administrators, and students of theology, church history, and of social sciences.

The conference was organized as the third interdisciplinary seminar on Religion arıd Society in Uppsala, Sweden jointly by the Nordic Institute of Missionary and Ecumenical Research, and the Scandinavian Institute of African Studies.

Published by:

Nordiska Afrikainstitutet

(The Scandinavian Institute of African Studies)

P.O. Box 1703, S-751 47 UPPSALA, Sweden 